\title{
CEsifo \\ WORKING

\section{How does for-profit college attendance affect student loans, defaults and labor market outcomes?}

Luis Armona, Rajashri Chakrabarti, Michael F. Lovenheim 


\section{Impressum:}

CESifo Working Papers

ISSN 2364-1428 (electronic version)

Publisher and distributor: Munich Society for the Promotion of Economic Research - CESifo

$\mathrm{GmbH}$

The international platform of Ludwigs-Maximilians University's Center for Economic Studies and the ifo Institute

Poschingerstr. 5, 81679 Munich, Germany

Telephone +49 (0)89 2180-2740, Telefax +49 (0)89 2180-17845, email office@cesifo.de

Editor: Clemens Fuest

www.cesifo-group.org/wp

An electronic version of the paper may be downloaded

- from the SSRN website: www.SSRN.com

- from the RePEc website: www.RePEc.org

- from the CESifo website: www.CESifo-group.org/wp 


\title{
How does for-profit college attendance affect student loans, defaults and labor market outcomes?
}

\begin{abstract}
For-profit providers are becoming an increasingly important fixture of US higher education markets. Students who attend for-profit institutions take on more educational debt, have worse labor market outcomes, and are more likely to default than students attending similarly-selective public schools. Because for-profits tend to serve students from more disadvantaged backgrounds, it is important to isolate the causal effect of for-profit enrollment on educational and labor market outcomes. We approach this problem using a novel instrument combined with more comprehensive data on student outcomes than has been employed in prior research. Our instrument leverages the interaction between changes in the demand for college due to labor demand shocks and the local supply of for-profit schools. We compare enrollment and postsecondary outcome changes across areas that experience similar labor demand shocks but that have different latent supply of for-profit institutions. The first-stage estimates show that students are much more likely to enroll in a for-profit institution for a given labor demand change when there is a higher supply of such schools in the base period. Among four-year students, for-profit enrollment leads to more loans, higher loan amounts, an increased likelihood of borrowing, an increased risk of default and worse labor market outcomes. Two-year for-profit students also take out more loans, have higher default rates and lower earnings. But, they are more likely to graduate and to earn over $\$ 25,000$ per year (the median earnings of high school graduates). Finally, we show that for-profit entry and exit decisions are at most weakly responsive to labor demand shocks. Our results point to low returns to for-profit enrollment that have important implications for public investments in higher education as well as how students make postsecondary choices.
\end{abstract}

JEL-Codes: I230, I260, J240.

Keywords: postsecondary education, for-profits schools, student loans, default, returns to education.

\section{Luis Armona \\ Stanford University / CA / USA \\ larmona@stanford.edu}

Rajashri Chakrabarti

Federal Reserve Bank of New York / USA

rajashri.chakrabarti@ny.frb.org
Michael F. Lovenheim

Cornell University / Ithaca / NY / USA

mfl55@cornell.edu 
February 2019

We thank Eric Bettinger, Julie Cullen, Stephanie Cellini, Giacomo De Giorgi, Enrico Moretti, Richard Mansfield, Arnaud Maurel, Matthew Notowidigdo, Jonah Rockoff, Caroline Hoxby, Lesley Turner, Sarah Turner, Seth Zimmerman and seminar participants at the American Economic Association conference, NBER Economics of Education Program Meeting, Columbia University, Federal Reserve Bank of Cleveland, Louisiana State University, University of Illinois-Chicago, University of Texas at Austin, University of Utah, University of Connecticut, CESifo Conference on the Economics of Education, and the AEFP and APPAM Annual Meeting for valuable comments. John Grigsby, Michelle Jiang and Michael Stewart provided excellent research assistance. The views expressed in this paper are those of the authors and do not necessarily reflect the position of the Federal Reserve Bank of New York or the Federal Reserve System. All results, conclusions and errors are our own. 


\section{Introduction}

One of the most dominant trends in the US postsecondary market over the past several decades has been the rise in for-profit institutions and enrollments. As of 2000, 450,000 students were enrolled in the for-profit postsecondary sector, which represented $2.9 \%$ of all higher education enrollment. By 2015, over 1.3 million students, or $6.7 \%$ of all enrollments, were in a for-profit institution. The rise of for-profit enrollment over this period has been driven in part by a $60 \%$ increase in the number of for-profit schools, from 789 to 1262.1 Over 223,000 AA or BA degrees were conferred by for-profit colleges and universities in 2016, which is $7.6 \%$ of all such degrees awarded in that year.

With the precipitous rise in the for-profit postsecondary sector has come a growing concern that students are not well-served by attending these schools. They often charge higher tuition than their public counterparts of similar quality, and students have lower completion rates and longer time-to-degree than other similarly-selective institutions. Students also tend to have much lower earnings post-attendance at a for-profit college relative to their non-profit and public counterparts. This pattern is associated with high student loan default rates of forprofit students: $39 \%$ percent of those who defaulted on their federal loans in the 2012 repayment cohort had attended for-profit colleges, while only $11.5 \%$ of students were enrolled at for-profit schools in the 2010-11 academic year (Chakrabarti, Lovenheim and Morris 2016a). Concerns about predatory behavior among for-profit postsecondary institutions led to heightened student loan regulations during the Obama administration, but the Trump administration has rolled back many of these rules (Stratford 2017). These policy changes underscore the importance of more fully understanding how for-profit enrollment affects student outcomes.

For-profit schools are much more likely to cater to students from lower-income backgrounds, first generation college attendees and under-represented minority students than are public and not-for-profit institutions (Chakrabarti, Lovenheim and Morris 2016b; Deming, Goldin and Katz 2012). Because they serve a larger proportion of students from disadvantaged backgrounds, the worse postsecondary and labor market outcomes associated with for-profit enrollment are not necessarily indicative of a causal effect of these institutions. Identifying the causal effect of for-profit enrollment is of high importance for two reasons. First, the federal government spends a large amount on financial aid for students attending for-profit colleges. About $17 \%$ of Pell grants and Stafford loans go to for-profit undergraduate students, totalling

\footnotetext{
${ }^{1}$ These tabulations come from the 2017 Digest of Education Statistics.
} 
over $\$ 17$ billion (Trends in Student Aid 2017) ? $^{2}$ Second, the return to enrolling in a particular postsecondary institution is a core component of the human capital investment decision (Becker 1962). With substantial information asymmetries in the higher education market, especially for students from low-income and minority backgrounds (Hoxby and Avery 2013; Hoxby and Turner 2013; Arcidiacono and Lovenheim 2016b), there is scope for students to enroll in colleges that ultimately do not benefit them because they do not know it is a bad investment at the time of enrollment. For-profit colleges typically do not practice selective admissions, and there usually are local, lower-priced nonselective public colleges or universities that students could attend instead (Deming, Goldin and Katz 2013). Whether students and taxpayers would be better served by shifting attendance from for-profits to these other similarly-selective local options currently is poorly understood.

In this paper, we estimate the effect of attending a for-profit college relative to a local public college or university on financial aid, student debt, educational, and labor market outcomes using a novel identification strategy based on local labor demand shocks combined with the latent supply of postsecondary schools in an area. Employing administrative institution-level data on enrollment, graduation, financial aid, student debt, default, and subsequent employment and earnings, we leverage the fact that higher education enrollment tends to increase when there is an adverse local labor demand shock and vice versa (Betts and McFarland 1995; Christian 2007; Clark 2011; Hershbein 2012; Aguiar, Hurst and Karabarbounis 2013; Long 2014; Chakrabarti, Lovenheim and Morris 2016). This is because negative labor demand shocks lower the opportunity cost of college for both recent high school graduates and recently unemployed workers who are seeking to increase their skill levels. With positive labor demand shocks the opportunity cost of college increases and these groups find it more remunerative be in the labor force.

We construct 3-year rolling labor demand shocks from 2000-2014 at the Core Based Statistical Area (CBSA) level using the shift-share labor demand instrument first introduced by Bartik (1991). The approach entails interacting baseline employment share of an industry in a local area with national trends in that industry's employment shares. We use industries defined by 2-digit NAICS codes as well as national trends outside of each CBSA to measure local labor demand conditions. Our main innovation comes from interacting this labor demand measure with for-profit penetration in the base year (2000) $]^{3}$ in the CBSA. We thus leverage the intuition (that we later test in the paper) that enrollment in for-profits should be higher in areas that

\footnotetext{
${ }^{2}$ This understates federal expenditures on for-profit students because it ignores veteran benefits provided by the post-9/11 GI Bill (Barr 2015).

${ }^{3}$ In this paper, we refer to academic years by the calendar year of the spring semester. Thus, 2000 refers to the $1999-2000$ academic year.
} 
have a higher baseline supply of such schools for a given labor demand shock. Critically, we are not identified off of baseline higher education supply conditions ${ }^{4}$ or off of differences across cities in the size of a labor demand shock. Rather, the instrument we use exploits the interaction of these two forces: we compare changes in outcomes among two otherwise similar CBSAs that experience similar changes in labor demand at the same time but that have different baseline postsecondary supply conditions. The main identification assumption we invoke is that there are no contemporaneous shocks or trends in our outcomes of interest that are correlated with the timing, magnitude, and sign of local labor demand changes as well as with the initial supply of for-profit schools. That we have positive and negative labor demand shocks is a particular strength of our approach because it insulates us from biases associated with any uni-directional secular trends in outcomes that are correlated with for-profit supply. Furthermore, we demonstrate that baseline for-profit supply and labor demand changes are only weakly correlated with each other and are uncorrelated with pre-2000 trends in the outcomes we study, which makes it unlikely unobserved factors bias our estimates.

We measure for-profit supply by the percentage of for-profit schools in each CBSA of each level (two- or four-year) in 2000 $]^{5}$ We find that the interaction of the percentage of four-year (or two-year) for-profit schools at the CBSA level in the 1999-2000 academic year interacted with the predicted labor demand measure is a strong instrument for four-year (two-year) for-profit enrollment $\sqrt[6]{6}$ For a 1 percentage point negative labor demand shock, enrollment at 4-year forprofit schools increases by 230 students when the for-profit share in 2000 is 1 percentage point higher. Among two-year schools, the effect is 105 students. Both estimates are statistically different from zero at the $1 \%$ level. These findings are of interest in their own right, as they demonstrate the importance of local postsecondary supply conditions in determining enrollment patterns following a recession, and they suggest that for-profit schools played a significant role in many areas in worker training during the great recession. To our knowledge, these patterns have not been shown previously, and they further underscore the policy importance of understanding how for-profit enrollment affects student outcomes.

In the second stage, our results point consistently to worse outcomes among for-profit students relative to public students. Among four-year students, there is a negative effect of attending a for-profit school for each outcome we consider. Relative to public school students,

\footnotetext{
${ }^{4}$ Prior research beginning with the seminal work of Card (1995) has used cross-sectional variation in postsecondary supply conditions as an instrument for college-going. Another strand of research uses changes in the supply of postsecondary institutions as an instrument (Currie and Moretti 2003). Our approach relaxes the often strong assumptions underlying cross-sectional estimators and allows us to use more recent data from a time period in which there was little postsecondary entry or exit.

${ }^{5}$ Two-year institutions include less-than-two-year schools as well. We call this group "two-year schools" throughout the paper.

${ }^{6}$ In this paper, sector refers to for-profit or public schools while "institution type" or "level" refers to two- or four-year schools.
} 
for-profit students take out one additional federal loan on average and originate over $\$ 3,300$ more in loan debt. This increased loan debt reflects a higher likelihood of taking out both subsidized and unsubsidized loans, and we show it is driven in part by higher tuition levels faced by for-profit students. In addition to taking on more debt, for-profit students may be more likely to default and to face worse labor market outcomes. This is indeed what we find: for-profit students are 11 percentage points less likely to be employed and have lower earnings than their public school counterparts. They also are less likely to obtain a BA, although we note that the earnings and graduation estimates are not statistically different from zero at conventional levels. Taken together, the labor market estimates indicate that four-year for-profit students experience lower returns to their postsecondary investment than public four-year students.

In two-year colleges, we find that for-profit students take out more loans, originate higher loan amounts, and are more likely to default. While two-year for-profit students are more likely than their public counterparts to obtain a degree, they are less likely to be employed after six years and have lower earnings. However, they are more more likely to earn over $\$ 25,000$ per year - the median earnings for a high school graduate - suggesting that these students may be better off than not having enrolled in college. Though many of these estimates are not precisely estimated, they suggest that for-profit two-year enrollment leads students to take on more debt without enhanced labor market outcomes relative to community college enrollment. As discussed below, our results accord with much of the burgeoning literature on the for-profit sector, with the distinction that our identification strategy is better able to account for selection across institution types than is possible in much of the extant research.

We also examine how for-profit as well as public college entry/exit responds to labor demand shocks. For-profits are slightly more likely to enter when there is a negative labor demand shock, suggesting these institutions are somewhat responsive to increases in student demand. No such entry/exit effects are apparent for public colleges and universities. We additionally show that entry/exit effects are not occurring differently across the pre-existing supply distribution in a manner that could drive our results.

This analysis relates most closely to the body of research that examines the return to forprofit enrollment. There is growing descriptive evidence that students at for-profit schools take on more debt and have worse labor market outcomes than their counterparts in non-for-profit colleges and universities (Looney and Yannelis 2015; Cellini and Darolia 2016; Chakrabarti, Lovenheim and Morris 2016a; Scott Clayton 2018). These papers show that student loan levels have risen dramatically in the for-profit sectors and that the lower labor market prospects for 
these students are associated with higher loan default levels. Of concern in interpreting these patterns as causal is that for-profit institutions typically serve a more disadvantaged population; this selection mechanism could drive much of the adverse outcomes associated with for-profit enrollment.

A number of influential studies have advanced beyond descriptive analysis by addressing this selection bias in various ways. The most common approach is to employ selection-on-observables methods using datasets with rich student background characteristics (Deming, Goldin and Katz 2012; Liu and Belfield 2014a; Denice 2015; Lang and Weinstein 2012, 2013). Deming, Goldin and Katz (2012) is the first and most prominent paper to use this method, employing data from the Beginning Postsecondary Students (BPS) dataset. They compare for-profit students to observationally-similar non-for-profit students and find large negative effects of the for-profits on employment outcomes. These results are broadly representative of the findings from other research using this method, though Lang and Weinstein (2012, 2013) find more muted effects when comparing associates degree and certificate recipients at for profit versus other postsecondary sectors. While an important advance in the literature, the identification assumption that even a rich set of observables can account for baseline productivity differences across students is strong.

Another set of studies employs individual fixed effects to identify the returns to for-profit enrollment, which controls more directly for selection-on-unobservables. However, this method can be biased by selection into for-profit schools based on unobserved shocks or trends. In addition, the use of student fixed effects requires one to focus on older students who have sufficient pre-enrollment earnings. Cellini and Chaudhary (2008) are the first to use this method to examine the returns to for-profit enrollment. They estimate how earnings of those enrolling in for-profit two-year degree programs change relative to the change in earnings among high school graduates who do not enroll. The comparison group in this study therefore is nonattendees rather than those who attend a local public college as in our application. While both comparisons are of interest, understanding how the decision to enroll in a for-profit versus a non-for-profit affects outcomes is a core policy parameter that their analysis cannot inform. Cellini and Chaudhary find a post-enrollment increase in earnings of about 10\% among forprofit attendees. Using a similar individual fixed effects strategy with US tax data, Turner (2011) and Cellini and Turner (2016) find that students enrolling in for-profits experience much less growth in earnings than those enrolling in public institutions. The latter analysis shows 
that for-profit students experience a decline in earnings relative to their pre-enrollment levels.7

The papers that most credibly overcome the selection biases associated with identifying the causal effect of for-profit enrollment are two randomized audit studies (Darolia et al. 2015; Deming et al. 2016). These studies sent resumes to potential employers and randomly included a for-profit or a non-for-profit school as the education credential. Deming et al. (2016) find that listing a business or health degree from an online college (almost all of which are for-profit) significantly reduces the likelihood of callback relative to a nonselective public school. Darolia et al. (2016) find no adverse consequences of listing a for-profit degree. However, they focus only on sub-baccalaureate training in contrast to Deming et al. (2016). The differences in findings across these studies suggests it is important to consider four-year and two-year degrees separately, which we do in our analysis.

The prior for-profit research is consistent with a negative effect relative to enrolling in another type of non-selective institution. However, the most credible estimates in this literature can only examine earnings (in fixed effects studies) or call-back rates (in audit studies); the estimates that examine other outcomes (such as loans) rest on much stronger selection-onobservables assumptions. It is important to examine a broader set of outcomes using methods that can more plausibly account for selection to try to understand the myriad ways in which the decision to enroll in a for-profit college affects students in the long run. Furthermore, while the audit studies provide important insight into employer perceptions, one cannot necessarily translate these findings to labor market outcomes (Heckman 1998). They also only examine the effect of for-profit degrees rather than enrollment, which is an important distinction given the low completion rates that prevail among non-selective postsecondary institutions (Bound, Lovenheim, and Turner 2010).

We make several contributions to the literature. First, we propose a new method for identifying the effect of for-profit (relative to public) enrollment on student outcomes that we argue more plausibly accounts for selection bias than prior work using secondary data. Second, we examine a wide array of outcomes relative to the studies that employ more credible identification strategies, which allows us to paint a more complete picture of how for-profit enrollment affects students. Third, the variation we use is of independent interest given the high policy concern surrounding worker training. We provide new evidence on how the local supply of postsecondary institutions affects enrollment decisions in an economic downturn, which in turn

\footnotetext{
${ }^{7}$ Liu and Belfield (2014b) use individual fixed effects to show that students who transfer from a community college to a for-profit experience lower wage growth than community college students who do not transfer. Jepsen, Mueser and Jeon (2016) find large returns to for-profit enrollment in Missouri using student fixed effects, but they do not compare those returns to those from other postsecondary sectors.
} 
impacts returns to postsecondary investments. Our results thus inform worker training policies, and they have implications for the dynamics of how localities recover from recessions. While our estimates are local to students who enroll in college because of labor demand variation, this is clearly a group of immense importance. We are the first to analyze the returns to for-profit enrollment decisions among such students. 8 Our approach also is of interest because it provides a new strategy for using supply variation to identify postsecondary enrollment effects with more recent data and without the strong assumptions used by prior research. Fourth, we examine both four-year and two-year enrollment and outcomes. Fifth, we are the first to examine how for-profit entry and exit respond to local labor demand changes and, in addition, how entry/exit responds to postsecondary supply given local labor demand conditions.9 Taken together, our results provide important new insight into the role played by local labor demand and higher education supply conditions in postsecondary enrollment and subsequent labor market and credit outcomes.

\section{Data}

The data we use in this analysis come from five sources: Quarterly Census of Employment and Wages (QCEW), Integrated Postsecondary Education Data System (IPEDS), National Student Loan Data System (NSLDS), College Scorecard data (CSD), and the US Census. We discuss each of these datasets in turn.

\subsection{Measuring Labor Demand Shocks}

We measure labor demand shocks using the shift-share approach pioneered by Bartik (1991). This entails combining baseline industry employment shares in a local area with changes in national employment shares in that industry outside of the local area. We use QCEW data from 1997-2014 that contain administrative employment information taken from establishments that report to state unemployment insurance systems. The QCEW covers about 97\% of civilian workers across the US. Our main sample uses 2-digit North American Industry Classification

\footnotetext{
${ }^{8}$ Jacobson, LaLonde and Sullivan (2005) show that community college enrollment increases future earnings among displaced workers. Jepsen, Troske and Coomes (2014) also find large but heterogeneous returns to community college degrees. They focus on somewhat older students who have pre-collegiate earnings, many of whom are likely to be displaced workers. Neither study examines the differential returns to for-profit versus community colleges, which is the parameter of interest in our analysis.

${ }^{9}$ Gilpin, Saunders and Stoddard (2015) show that for-profit enrollment and completions among two-year students are responsive to local labor market conditions: increased labor demand in certain occupations leads to increased enrollment and completion in for-profits but not publics. They do not examine four-year institutions, which we show to be empirically important, nor do they account for the potential endogeneity of labor demand. They also do not exploit the interaction of postsecondary supply and labor demand in local labor markets, and they do not examine the breadth of outcomes we consider. However, our first-stage estimates align qualitatively with theirs in showing that the for-profit sector is more demand elastic than the public sector.
} 
System (NAICS) industry codes at the CBSA level to measure employment shares. We use 2-digit NAICS codes because the less-aggregated 3- and 4-digit codes have a high prevalence of missing values driven by nondisclosure and introduce much more error into the measure. Our labor demand measure is not terribly sensitive to using 3-digit or 4-digit NAICS codes, however.

Using the QCEW data, we construct predicted rolling 3-year labor demand shocks $(\hat{\eta}))^{10}$ for CBSA $(c)$ in year $(t)$ and state $(s): 11$

$$
\hat{\eta}_{c t}=\sum_{k=1}^{K} \gamma_{k c, t-3} \eta_{k q t}
$$

where $\gamma$ is the employment share of industry $k$ in baseline year $t-3$ and CBSA $(c)$ and $\eta$ is the percentage change in employment share of industry $k$ between $t-3$ and $t$ outside of CBSA $c$. Thus, we use national employment share changes outside of the CBSA in order to guard against the possibility that national changes are influenced by endogenous labor demand shifts within the CBSA. Note that rather than fix the employment share in a common year, the employment share changes across baseline years. This creates a stronger measure of actual labor demand changes over our long panel but is potentially concerning if changes in the base employment share are endogenous. We underscore that our focus is on the interaction of labor demand changes and a baseline higher education supply measure that does not change over time. A strength of our model is that we control for $\hat{\eta}_{c t}$ directly, which accounts for unobserved heterogeneity that could be correlated with industrial share changes, baseline for-profit supply, and our outcomes of interest. Furthermore, in results available upon request, we find that our estimates are robust to using CBSA employment shares in 2000 rather than varying baseline shares 12

Figure 1 shows the geographic variation in labor demand changes across CBSAs from 19972000. Just in this one year (2000), there is a large amount of variation: some areas experience modest positive labor demand increases while others experience sizable contractions. There also is little spatial correlation among these changes that is evident from Figure 1. Within relatively concentrated geographic areas, one can find cities that are experiencing reductions

\footnotetext{
${ }^{10}$ We have estimated our models using 1-year rolling labor demand shocks and find very similar results. These estimates are available from the authors upon request.

${ }^{11}$ Our notation follows Autor and Duggan (2003), who construct similar 3-year rolling labor demand averages at the state rather than at the CBSA level.

${ }^{12}$ Specifically, we calculate an alternative labor demand measure $\hat{\eta}_{c t}=\sum_{k=1}^{K} \gamma_{k c, 2000} \eta_{k q t}$. The labor demand changes measured in this way represent cumulative shocks relative to the 2000 baseline. That the cumulative and rolling shock measures yield almost identical estimates suggests allowing the baseline share to update does not meaningfully affect our results and conclusions.
} 
and increases in labor demand. The sign and magnitude of these changes varies considerably within CBSA over time as well, which is shown in Figure 2. The figure shows the size of labor demand changes by quartile. While $50 \%$ of the distribution experiences small positive and negative shocks, large labor demand changes also are prevalent. The recessions of the early 2000s and 2008 are clearly evident. There also are many areas in each year that experience positive and negative shocks as well as areas that experience little change in labor demand. Our identification strategy rests heavily on this large amount of variation in the sign and magnitude of labor demand changes.

\subsection{Measuring For-profit Supply, Student Outcomes and Demographic Charac- teristics}

Our measure of for-profit supply is the proportion of postsecondary institutions in 2000 in each CBSA that are for-profit. ${ }^{13}$ This is measured using 2000 IPEDS data. Census crosswalks locate public and for-profit institutions in CBSAs, and we construct a separate measure for two-year and four-year institutions. Throughout, we exclude all not-for-profit institutions because the composition of the for-profit market is much more similar to the public market than to the notfor-profit market. Eighty-two percent of for-profit institutions are less than four-year, while $68 \%$ of public institutions are less than four-year. However, only $17 \%$ of private, not-for-profit colleges and universities are at the two- or less-than-two year level. Sixty-seven percent of degrees conferred by private, not-for-profit schools are graduate degrees and $28 \%$ are BAs. In the public sector, these percentages are 38 and 32, respectively, while in the for-profit sector they are 12 and 5\%, respectively. These tabulations suggest that the private, for-profit sector is very different from the not-for-profit sector in ways that makes it unlikely students will be deciding between attending a for-profit versus a not-for profit institution. Rather, the decision set of most students considering a for-profit probably consists of public and for-profit institutions 14

Figures 3 and 4 show the proportion of two-year and four-year institutions that are forprofit by CBSA in 2000. There is much heterogeneity across space. While there are many more CBSAs without a for-profit four-year school than without a two-year school, for-profit schools

\footnotetext{
${ }^{13}$ A strong argument can be made for using for-profit enrollment percentage as our measure of for-profit supply instead. The goal of our supply measure is to capture the ability of the for-profit sector to absorb increases in student demand that are driven by labor demand shocks. First-stage estimates using the proportion of enrollment in for-profit institutions in 2000 are shown in Online Appendix Table A-7. The instrument is weak, though the point estimates are in the same general direction as those that use the percentage of for-profit institutions (Table 3). Thus, we find empirically that the percentage of for-profit institutions better captures how the elasticity of enrollment with respect to labor demand shocks changes as a function of local postsecondary supply conditions than does the proportion of students enrolled in for-profit institutions. We therefore focus on this supply measure throughout the paper.

${ }^{14}$ In results not reported, we show our estimates are robust to including not-for-profit institutions.
} 
are not clustered in any particular part of the country, and their prevalence varies even across nearby CBSAs. This suggests that there is much idiosyncratic variation in for-profit penetration that we can use for identification. Examining the distribution of for-profit supply shows there is heaping at 100\% among two-year schools. Sixty-five CBSAs have only for-profit two-year institutions; we exclude these CBSAs from the analysis because students in these areas do not have a public option and these CBSAs are unlikely to be similar to areas with both public and for-profit schools.

Enrollment data come from IPEDS. We focus on total 12-month enrollment, but we show below that our results and conclusions are robust to using 12-month undergraduate enrollment and various fall enrollment measures such as total enrollment, undergraduate enrollment, full-time equivalent enrollment, and full-time enrollment.15 For graduation, we exploit data on degree recipients within 150\% time (3 years for 2-year graduates and 6 years for 4 -year graduates) at the institution-entering cohort level. That is, we measure the number of graduates in each year from cohorts 3 or 6 years ago. To construct this measure, we multiply the $150 \%$ graduation rate by the enrollment size of the cohort 3 or 6 years ago. The result is a cohort-based number of graduates 16

One complication with using IPEDS data is that while participation in IPEDS surveys is mandatory for institutions that disburse federal financial aid (Title IV institutions), it is voluntary for non-Title IV institutions. Consequently, non-Title IV schools are not well represented in the data. Many for-profit institutions are not Title IV institutions (Cellini and Goldin 2014), which leads us to under-count for-profit colleges. Much of the previous literature using IPEDS data to study for-profit institutions also faces this limitation (Deming, Goldin and Katz 2012; Darolia 2013). This essentially creates measurement error in our instrument. As long as the measurement error is uncorrelated with local labor demand shocks, it should attenuate the first stage but not bias our estimates. Furthermore, the number of for-profits in the IPEDS data is not correlated with our instrument (see Section 4.4), which suggests our identifying variation is not related to schools entering or exiting the data due to Title IV disbursement (or any other reason) 17

\footnotetext{
${ }^{15}$ Twelve month enrollment measures include all students enrolled during the 12-month reporting period (July 1 - June 30 ) for credit. Fall enrollment measures only include students enrolled for credit as of the institution's fall reporting date (or October 15) of the corresponding academic year. Since our outcome measures relate to students enrolled during the 12-month period (not just fall), the 12-month enrollment measure is the most relevant.

${ }^{16}$ We focus on $150 \%$ completion rate because $100 \%$ and $200 \%$ completion rates are only available for a small subset of our time period, while $150 \%$ graduation rate spans the entirety of our analysis period.

${ }^{17}$ As discussed below, another complication with IPEDS data is that four-year institutions are defined as any school that awards at least one Bachelors degree. We use this definition as our baseline but show extensive evidence that our results are robust to different definitions of four-year institutions in Section 4.3.
} 
Data on financial aid at the institution-year level comes from the National Student Loan Data System (NSLDS). The NSLDS data are comprised of administrative information on all Title IV federal student loan originations. For each institution and year, we exploit the total number of loans originated as well as originations by four loan types: direct unsubsidized loans, direct subsidized loans, subsidized loans under the Federal Family Education Loan (FFEL) Program, and unsubsidized FFEL loans. In addition to the number of originations, the data contain the value of all loans originated both overall and by type. These data are aggregated to the institution-year level, so while we have detailed financial aid outcomes for each college and university we cannot link them to specific students.

We supplement these data with information on two-year cohort default rates by institution and year from the US Department of Education. Cohorts in the default data are assigned based on when students first enter repayment, which typically occurs upon graduation or dropout. ${ }^{18}$ The two-year cohort default rate is defined as the proportion of students entering repayment in a fiscal year who default by the end of the subsequent fiscal year.

The final dataset we use to measure student outcomes is the College Scorecard, which contains earnings and employment post-enrollment for all students who received Title IV federal aid while in college. The fact that the data only include students who receive federal aid creates a potential endogeneity concern if our identifying variation affects aid receipt. We show below that our instrument is unrelated to the share of students receiving Pell grants or federal loans (see Table 2), which suggests that our labor market estimates are not biased by endogenous selection into the College Scorecard sample. ${ }^{19}$ The College Scorecard data come from US tax records and record earnings for each incoming cohort of students from each institution between 6 and 10 years after first enrolling. We observe the number of students from each institution and cohort who are employed and not employed (including unemployed). The CS data also contain mean earnings by cohort and institution, excluding those who are not employed and those who are enrolled in any postsecondary institution, including graduate school. We measure total earnings of each cohort $(y)$ from each institution $(j)$ by calculating the following: $\bar{W}_{y j} * \% e m p_{y j} * E_{y j}$, where $\bar{W}$ is mean earnings, \%emp is the cohort-institution employment rate, and $E$ is the number enrolled in the cohort at the given institution. Finally, we calculate the number of students earning over $\$ 25,000$ per year in 2014 dollars as the fraction earning

\footnotetext{
${ }^{18}$ If a student attends graduate school or enters a profession that qualifies for delayed loan repayment, she will not enter repayment upon leaving college.

${ }^{19}$ The College Scorecard data do not account for differences in the program mix across colleges. However, we show in Table 2 that our instrument is uncorrelated with the type of degree students attain. This findings indicates that variation in program mix across colleges is unlikely to confound our estimates.
} 
over $\$ 25,000$ multiplied by the enrollment level of the cohort.

Because our education data come at the institution level and because the labor demand shocks occur at the CBSA level, throughout the analysis we aggregate data to the CBSAsector-year level, separately for four-year and two-year institutions. Institutional sectors are either for-profit or public. Thus, separately for two- and four-year institutions, for each CBSA and year there are two observations for each variable: one observation that aggregates all for-profit institutions and one that aggregates all public institutions.

To match labor demand shocks to enrollment, we assume that enrollment responds to an observed labor demand change. We therefore match 3-year rolling labor demand shocks to next year's enrollment (i.e., a one-year lead of enrollment). ${ }^{20}$ For example, we link the labor demand shock from 2001-2004 (where 2001 is the base year, 2004 the end year) to enrollment in the 2005-06 academic year.21 Most of the outcomes we examine are linked directly to incoming cohorts. Loan default rates are more complicated to merge with our analysis dataset because they are observed with a lead. Our data on default correspond to cohorts in the "repayment" year, which is the year in which a student exits postsecondary enrollment because of graduation or dropout without a delayed payment exemption (such as public service or graduate school enrollment). To link default data to our incoming cohorts, we need to make assumptions about the length of time students spend in college. We assume students spend $100 \%$ of the statutory degree time in college, which means four-year students would be enrolled for 4 years and twoyear students would be enrolled for 2-years. Our results are robust to assuming 150\% time as well. The measurement error induced by our timing assumption is potentially problematic, but we believe it is most likely to bias our estimates towards zero to the extent we mismeasure the relationship between labor demand-induced entry and subsequent default outcomes. To create a serious bias in our results, it also would have to be the case that such measurement error is differential across the higher education sectors we consider. While possible, we know of no reason to believe this to be the case.

The final dataset we employ is from the US Census and contains year-by-CBSA demographic information. We obtain county-level estimates from the Census and use a county-CBSA crosswalk (also from the US Census) to aggregate up to the CBSA-year level. We construct measures of percent female, the racial composition of the CBSA (percent white, black, Hispanic, American Indian, Asian, and two or more races), the age distribution of the CBSA (percent 0-19,

\footnotetext{
${ }^{20}$ Online Appendix Table A-22 shows year ranges for all outcome variables we use in this study.

${ }^{21}$ Our QCEW data pertain to calendar years, while our education data pertain to academic years. So we assume that the shock in a calendar year (for example a shock that has 2004 as the end year) affects enrollment in the academic year starting the next fall (that is, the 2005-06 academic year).
} 
20-29, 30-39, and 40 or over), the poverty rate, and total population.

Table 1 contains descriptive statistics of our main analysis variables, overall and by institutional level and control ${ }^{22}$ In both the four-year and two-year sectors, for-profit schools are much smaller than their public counterparts. Consistent with Figure 2, the mean labor demand change is about $-1 \%$, but there is much heterogeneity as illustrated by the relatively large standard deviation. As expected, for-profit students are more likely to take out loans and to default once one scales the number of borrowers and defaulters by enrollment. Earnings among two-year attendees are much lower than among four-year attendees, but the difference between for-profit and public attendees is larger in two-year than in four-year institutions.

\section{Empirical Approach}

\subsection{Methodology}

The core identification concern with estimating the returns to investing in different postsecondary options is omitted variable bias: students likely sort into different colleges and universities based on skills and preferences that are difficult to observe and that correlate with labor market outcomes. This problem has been the core focus of the returns to college quality literature (Brewer, Eide and Ehrenberg 1999; Black and Smith 2004, 2006; Dale and Krueger 2002; Hoekstra 2009; Andrews, Li and Lovenheim 2016). The majority of this research has examined highly- or moderately-selective schools where selection on unobserved dimensions of skill is likely to be a first-order concern. Selective postsecondary markets are highly geographically integrated (Hoxby 2009, 2014), which means that the decision to enroll in a given institution is not strongly linked to where students live. In contrast, most enrollment in postsecondary institutions is local: the vast majority of students usually attend the local community college, for-profit school or non-selective four-year institution. This feature of the US higher education system has two implications. First, it creates market power among institutions in local markets in which the supply of colleges is low. Second, it creates considerable variation across local markets in the types of postsecondary institutions to which students have access. If a student is in an area with many local options that include public and for-profit schools at the two-year and four-year levels, they can exercise much more control over their postsecondary investment than a student who lives in an area with more limited options.

\footnotetext{
${ }^{22}$ Online Appendix Table A-1 contains descriptive statistics separately for the periods 2000-2006 and 2008-2014 and Table A-3 shows tabulations for CBSA-level observables.
} 
That the variation in supply of postsecondary institutions across areas can plausibly affect how students sort into different types of schools depending on where they live has been a focus of prior research. Previous studies attempting to use geographic variation in supply conditions either used cross-sectional variation in supply (Card 1995) or exploited changes in college openings over time (Currie and Moretti 2003). The former approach embeds the strong assumption that institutional location is exogenous, while the latter relies on there being sufficient variation in school openings (as well as the exogeneity of their locations). In recent years, there have not been large changes in the supply of postsecondary institutions outside of the for-profit sector, and the location of for-profit openings and closings is likely endogenously related both to the demand for these institutions and to existing supply conditions.

We augment these prior approaches by using the interaction of demand shocks for college with pre-existing postsecondary supply conditions in cities. This allows us to employ cross-city variation in postsecondary supply conditions without having to rely solely on this variation for identification. Thus, our method provides a way to use variation in higher education supply to identify the returns to postsecondary investment decisions using more recent college-going cohorts and in a manner that does not rely on the strong cross-sectional assumptions invoked in prior work. Specifically, we exploit the fact that people are more likely to enroll in college when labor demand is low because of the reduced opportunity cost of enrollment in terms of foregone earnings ${ }^{23}$ Resulting changes in the demand for college then interact with baseline postsecondary supply conditions to generate variation in where students enroll. The thought experiment underlying our method is to consider two cities that experience identical labor demand changes (say, negative) in a given year but that have a different pre-existing supply of for-profit colleges. The reduction in labor demand increases the demand for college enrollment in both cities, but enrollment in for-profits should increase more in the city with a higher supply of for-profit institutions when this common demand shock occurs. Labor demand changes are not identical across cities, however, and so we exploit the interaction between these shocks and pre-existing for-profit supply conditions in an area.

To fix ideas, consider a sector-specific IV mode ${ }^{24}$ in which we estimate how outcomes change in each sector $(j \in\{$ for-profit,public $\})$ when enrollment changes as a function of the interaction of pre-existing postsecondary supply and labor demand shocks. We consider this model

\footnotetext{
${ }^{23}$ It is not obvious that enrollment will increase when labor demand declines, because low labor demand can cause credit constraints to bind. Consistent with the prior literature (e.g., Christian (2007) and Hershbein (2012)), we show that any credit constraint effects are swamped by opportunity cost effects. As a result, enrollment in local postsecondary institutions increases when labor demand declines.

${ }^{24}$ Recall that throughout the analysis, sector distinguishes between for-profit and public schools while "institution type" or "level" refers to two-year or four-year school types.
} 
separately for two-year and four-year institutions:

$$
\begin{aligned}
& E_{c s t}^{j}=\alpha_{0}^{j}+\alpha_{1}^{j} \hat{\eta}_{c, t-1}+\alpha_{2}^{j}\left(\hat{\eta}_{c, t-1} * \text { Supply }_{c}\right)+\alpha_{3}^{j} L_{c, t-4}+\lambda^{j} X_{c t}+\delta_{c}^{j}+\psi_{s t}^{j}+\mu_{c s t}^{j} \\
& Y_{c s t}^{j}=\beta_{0}^{j}+\beta_{1}^{j} \hat{\eta}_{c, t-1}+\beta_{2}^{j} \hat{E}_{c s t}^{j}+\beta_{3}^{j} L_{c, t-4}+\kappa^{j} X_{c t}+\phi_{c}^{j}+\theta_{s t}^{j}+\epsilon_{c s t}^{j},
\end{aligned}
$$

where $Y$ is our outcomes of interest in institution sector $j$ in CBSA $c$ in state $s$ and year $t$ and $E$ is total 12 -month enrollment in the CBSA-sector-year. The variable $\hat{\eta}$ is calculated using the formula shown in equation (1) and measures the labor demand change between time period $t-4$ and $t-1$ that we then link to enrollment for the cohort entering college in time t. Supply is the proportion of postsecondary institutions in 2000 that are for-profit among all for-profit and public institutions (estimated separately by institution level) ${ }^{25}$ The model also includes $\operatorname{CBSA}\left(\phi_{c}, \delta_{c}\right)$ and state-by-year $\left(\theta_{s t}, \psi_{s t}\right)$ fixed effects. We include a set of controls $(X)$ that account for changes in the composition of CBSAs over time: percent female, the racial composition of the CBSA (percent black, Hispanic, American Indian, Asian, and two or more races), the age distribution of the CBSA (percent 20-29, 30-39, and 40 or over), the poverty rate, and total population. Finally, we control for base period $(t-4)$ total employment $(L)$ that helps account for any changes in the size of the workforce that could be correlated with labor demand changes.

Equation (2) shows the first stage and equation (3) shows the second stage of the IV model. The coefficients of interest are $\beta_{2}^{F P}$ and $\beta_{2}^{\text {public }}$, which identify how aggregate outcomes in the CBSA-sector-year change when enrollment changes by one student in the CBSA-sector-year. The variation in enrollment is driven by the interaction of labor demand shocks between periods $t-4$ and $t-1$ and the baseline prevalence of for-profit institutions relative to public institutions in an area. Estimating this model separately by sector is akin to a difference-in-difference model with a continuous treatment measure, the sign of which varies over time. When there is a negative labor demand shock, we expect more students to attend college and to attend for-profits in higher numbers when there are more such institutions.

Estimating this model separately by sector is feasible, but interpreting the estimates is made difficult by the lack of a clear comparison group. The sector-specific instrumental variables model shows how aggregate outcomes change when enrollment grows by one student in forprofits or publics due to variation in the instrument. The motivating question of this analysis is

\footnotetext{
${ }^{25}$ Another way to proceed would be to control separately for number of for-profits and number of publics in the baseline year (2000). Combining these two supply measures into a single share variable simplifies the model without altering the underlying supply variation being used.
} 
how $\beta_{2}^{\text {for-profit }}$ compares to $\beta_{2}^{\text {public }}$ : we want to estimate the returns to enrollment in a for-profit relative to a public institution, as this is the margin of choice for most students. Additionally, the sector-specific regressions are highly demanding of the data due to the need to estimate separate sector-specific coefficients for each CBSA, state-year and control variable. To increase statistical power and to facilitate comparisons across sectors, we stack the CBSA-sector-year level data together and estimate an interacted model:

$$
\begin{aligned}
E_{j c s t}= & \alpha_{0}+\alpha_{1} \hat{\eta}_{c, t-1}+\alpha_{2}\left(\hat{\eta}_{c, t-1} * \text { Supply }\right)+\alpha_{3} F P_{j c t}+\alpha_{4}\left(\hat{\eta}_{c, t-1} * F P_{j c t}\right)+\alpha_{5}\left(S_{\text {Supply }} * F P_{j c t}\right) \\
& +\alpha_{6}\left(\hat{\eta}_{c, t-1} * \operatorname{Supply}_{c} * F P_{j c t}\right)+\alpha_{7} L_{c, t-4}+\lambda X_{c t}+\delta_{c}+\psi_{s t}+v_{s j}+\zeta_{t j}+\mu_{j c s t} \\
Y_{j c s t}= & \beta_{0}+\beta_{1} \hat{\eta}_{c, t-1}+\beta_{2} F P_{j c t}+\beta_{3}\left(\hat{\eta}_{c, t-1} * F P_{j c t}\right)+\beta_{4}\left(\text { Supply }_{c} * F P_{j c t}\right) \\
& +\beta_{5} \hat{E}_{j c s t}+\beta_{6} \hat{E}_{j c s t} * F P_{j c t}+\beta_{7} L_{c, t-4}+\kappa X_{c t}+\phi_{c}+\theta_{s t}+\omega_{s j}+\tau_{t j}+\epsilon_{j c s t} .
\end{aligned}
$$

The variable $F P$ is an indicator variable equal to 1 if the observation is for the for-profit sector. Thus, equations (4) and (5) are akin to a fully-interacted version of equations (2) and (3) subject to constraining the CBSA and state-year fixed effects as well as the effect of the CBSA-year composition controls and base period employment to be the same across for-profits and publics. Instead, we include state-by-for-profit, year-by-for-profit and supply-by-for-profit fixed effects to conserve power (details below). The instruments in the first stage are the interaction between $\hat{\eta}$ and Supply as well as the interaction between $\hat{\eta}$, Supply and FP. The former shows how public enrollment increases for a given labor demand change as a function of the for-profit supply in 2000. The latter shows how a labor demand shock affects enrollment in for-profits relative to publics when the baseline share of for-profits is larger. The two endogenous independent variables in equation (5), $\hat{E}_{j c s t}$ and $\hat{E}_{j c s t} * F P_{j c t}$, are instrumented with these variables ${ }^{26}$ The main coefficient of interest in equation (4) is $\alpha_{6}$, because it shows how a given labor demand shock and pre-existing for-profit supply translate into for-profit enrollment. We focus on this parameter when presenting our first stage results.

In addition to the CBSA fixed effects $(\delta, \phi)$ and state-by-year fixed effects $(\theta, \psi)$, equations (4) and (5) include state-by-for-profit fixed effects $(v, \omega)$, year-by-for-profit fixed effects $(\zeta, \tau)$, and lower order interactions among $\hat{\eta}$, Supply and FP. The state-by-year fixed effects account for any state-level economic shocks or policies that could be correlated with postsecondary choices

\footnotetext{
${ }^{26}$ There are two first-stage equations, with $E_{j c s t}$ and $E_{j c s t} * F P_{j c t}$ as the dependent variables. We focus on the first-stage estimates with $E_{j c s t}$ as the outcome variable below because it is more straightforward to interpret. First stage estimates for $E_{j c s t} * F P_{j c t}$ are more mechanical and are available upon request from the authors.
} 
or outcomes (such as higher education funding). State-by-for-profit and year-by-for-profit fixed effects control for the changing nature of for-profit institutions over time and across states. These controls help relax the assumption that the state-year fixed effects are common across sectors while being less computationally demanding than a fully interacted set of controls. It could be the case that certain states have more or less productive for-profit institutions or that unobserved dimensions of for-profit productivity are changing over time, both of which will be accounted for by these fixed effects.

We estimate equations (4) and (5) separately for four-year institutions and two- and lessthan-two-year institutions ${ }^{27}$ Supply is calculated separately for each level. Because there is likely to be serial correlation in the errors within CBSAs over time, we cluster all standard errors at the CBSA level 28

The coefficients of interest in the second stage are $\beta_{5}$ and $\beta_{6}$. Importantly, all lower-level interactions between $\hat{\eta}$, Supply and FP are included in the second stage, except for $\hat{\eta} *$ Supply, which is another excluded instrument. These controls allow us to account for independent effects of labor demand changes as well as for changes in the industrial share over time within CBSAs $\left(\beta_{1}\right){ }^{29}$ fixed differences between for-profit and public institutions $\left(\beta_{2}\right)$, differential effects of labor demand shocks on for-profit versus public institutions $\left(\beta_{3}\right)$, and differential changes in the for-profit sector as a function of 2000 supply $\left(\beta_{4}\right)$. The $S u p p l y_{c} * F P_{j c t}$ variable is unique to equations (4)-(5) and is not found in the sector-specific models. This is because Supply is fixed within CBSA (and thus is collinear with the CBSA fixed effects) and $F P$ does not vary within sector. Hence, we can interpret $\alpha_{5}$ and $\beta_{4}$ as parameterized versions of CBSA-by-sector fixed effects that show how for-profits differ systematically across CBSAs that have different baseline supply conditions.

Conditional on these controls, the main identifying variation comes from enrollment changes in each sector that are driven by the interaction of labor demand shocks and baseline supply. For a given labor demand shock, our model estimates how enrollment changes in each sector based on the prevalence of for profit versus public institutions. We then relate those changes

\footnotetext{
${ }^{27}$ About $5 \%$ of institutions switch from 2-year to 4 -year over our sample period. Online Appendix Table A-18 shows results fixing the institutional categorization in the base year. Results are very similar to our preferred results shown below that allow schools to switch 2-year/4-year status.

${ }^{28}$ The four-year estimates include selective and nonselective schools. This is potentially problematic if selective institutions are not substitutes for for-profit schools or if selective universities have geographically dispersed enrollment that comes from outside the local area. In Appendix Tables A-8 through A-11, we show estimates that exclude institutions that have an admissions selectivity rating of Highly Competitive or higher in the 2001 Barrons rankings. The first-stage and second-stage estimates are very similar in magnitude and statistical significance to baseline.

${ }^{29}$ Because we use rolling labor demand changes, the baseline industrial share changes in each year. Without controlling for these shares, some of the identifying variation comes from changes in the industrial composition within CBSAs over time. This variation is accounted for by controlling for $\hat{\eta}$, which includes the rolling baseline industrial employment share. We also have estimated models in which we fix the baseline share at 2000 levels. These estimates are very similar to baseline and are available upon request.
} 
in enrollment to changes in aggregate outcomes at the CBSA-year-sector level. Thus, $\beta_{6}$ shows how adding an additional student to the for-profit sector affects outcomes relative to adding an additional student to the public sector. As we discuss below, the enrollment changes in the first stage could come either from students who switch institution types due to the instrument (the switchers) or from students who otherwise would not have enrolled (the extensive margin). While we compare outcomes of marginal for-profit to marginal public students in the second stage, the estimates are not identified only off of those who switch across those sectors, but from both groups: the switchers and the extensive margin. Additionally, our estimates reflect a local average treatment effect that is driven in part by labor demand-induced college enrollment changes. This is an important source of variation to study as very little is known about the role of for-profits in worker training during economic downturns. Our estimates speak directly to this question.

\subsection{Validity of the Identifying Assumptions}

The main exclusion restriction underlying our approach is that the only reason that predicted labor demand shocks affect outcomes differently across the for-profit supply distribution is because of differential enrollment in for-profits. There are two sources of bias that could confound our estimates. The first is differential trends or shocks that are correlated with the timing, magnitude and sign of the predicted labor demand changes that differentially impact for-profit schools in places where the pre-existing supply of for-profits is higher. That is, a main threat to identification comes from unobserved factors that mimic the timing, sign, magnitude and geographic location of local labor demand changes and that also are correlated with Supply. A particular strength of our empirical design is that our estimates are much less sensitive to bias from secular trends than is the case in a typical panel data analysis because our labor demand measure varies in sign within a CBSA across time. Fifty-nine percent of CBSAs in our data experience both a positive and negative 3-year labor demand change between 2000 and 2014. Among the areas that have a negative labor demand shock in 2000, 46\% have a positive shock at some point in the future. Among CBSAs with a positive shock in 2000, $13 \%$ experience a negative shock in our sample. Thus, secular trends in outcomes should not impact our results unless they switch signs with the labor demand changes.

Predicted labor demand shocks are likely to be serially correlated across years both because of persistence of labor demand shocks within an area and because we use a three-year rolling measure. Any serial correlation could be related to secular trends in outcomes within a CBSA. 
To account for this concern, we show below that our results are robust to controlling for several leads of predicted labor demand shocks.

Bartik-style instruments are identified off of either cross-sectional variation in baseline industrial shares (Goldsmith-Pinkham, Sorkin and Swift 2018) or yearly shocks to national labor demand in given industries (Borusyak, Hull, and Jaravel 2018), which can potentially be problematic. However, we are identified off of the interaction between predicted labor demand and 2000 for-profit supply, not predicted labor demand per se. Because we control directly for predicted labor demand, even if this measure is endogeneously related to postsecondary enrollment and subsequent outcomes, our estimates only will be biased if these endogenous relationships also are correlated with postsecondary supply. The validity of our approach therefore is bolstered by the weak correlation between predicted labor demand changes and 2000 for-profit supply: the correlation is only 0.17 in our sample. Figures 5 and 6 provide graphical evidence of this result. Figure 5 shows the correlation between 2000 for-profit share and CBSA-year labor demand changes that are residual to the CBSA-specific mean. Both in the four-year and two-year markets, there is no evidence that labor demand changes are related to the relative size of the for-profit market in CBSAs ${ }^{30}$ Figure 6 presents trends of CBSA-demeaned labor demand shocks by for-profit supply. The top panel shows trends among four-year institutions and the bottom panel shows trends among two-year colleges. We present trends in predicted labor demand among those CBSAs with no for-profits and then with above and below median for-profit supply among areas with any for-profits. It is clear that the three groups exhibit near identical trends in labor demand changes over time. In Online Appendix Figure A-1, we show that the trends aggregated across school types also are similar. Taken together, these figures strongly suggest that labor demand changes within CBSAs are at most weakly correlated with 2000 for-profit supply heterogeneity. It therefore is very unlikely there are unobserved shocks that are correlated with both variables, which supports our identification strategy.

Further evidence that our estimates are not biased by secular variation related to industrial shares or for-profit supply comes from comparisons of pre-2000 trends in outcomes across the distributions of for-profit supply and predicted labor demand changes. Figure 7 presents trends in enrollment and outcome variables from 1996-1998 for CBSAs that are above and below the median interaction of 2000 supply and $\hat{\eta}{ }^{31}$ The panels of the figures thus test whether the

\footnotetext{
${ }^{30}$ As discussed in the previous section, we exclude CBSAs that only have for-profit two-year schools. We leave them in Figure 5 in order to show the full for-profit supply distribution.

${ }^{31}$ We are unable to examine pre-2000 trends for the number and volume of loans as the NSLDS data only are available beginning in 2000. However, we are able to include all other outcome variables in this analysis including student loan defaults (a loan outcome variable).
} 
value of the instrument in 2000 is correlated with pre-2000 outcome trends. The patterns are virtually identical across CBSAs with different instrument values in 2000, suggesting we are not picking up differential secular trends in our estimates. Online Appendix Figures A$2 \mathrm{a}$ and A-2b show similar trends by for-profit supply. There is no evidence that outcomes in areas with different for-profit penetration are changing differently prior to 2000. Importantly, pre-2000 trends in predicted labor demand changes are also similar across the for-profit supply distribution. Figures A-3a and A-3b additionally show that pre-2000 outcome trends are similar across CBSAs with above and below median labor demand shocks in 2000 as well as for those with positive versus negative labor demand shocks in 2000. Finally, Appendix Figure A-4 presents pre-2000 trends by whether CBSAs had a positive or negative value of the interaction between Supply and $\hat{\eta}$ in 2000. These results again show no evidence of differential trends. The lack of pre-2000 trends in outcomes as a function of for-profit supply and labor demand changes provides much support for our identification strategy, as any secular variation in outcomes needs to be correlated with both $\hat{\eta}$ and for-profit supply to cause a bias in our estimation of $\beta_{5}$ and $\beta_{6}$.

The second identification assumption is that the instrument variation does not generate a change in the composition of students at each institution type or lead to changes in institutional quality. If labor demand shocks generate changes in the types of students who attend each institution type (or lead to quality changes in institutions) differently across the postsecondary supply distribution, our estimates will confound such compositional changes with treatment effects ${ }^{32}$ For example, if labor demand declines cause more disadvantaged students to enroll in for-profit institutions when there is higher for-profit supply, our estimates may be picking up this compositional shift rather than the effect of for-profit enrollment on student outcomes. This is an important concern because, as we show below, total enrollment (for-profit plus public) increases due to a given negative labor demand shock when the proportion of for-profits rises. This is consistent with for-profits alleviating capacity constraints, and it increases the scope for bias from changes in the composition of students.

In order to determine the extent to which such factors change endogenously in a manner that may affect our results, we estimate a version of equation (4) in which the dependent variables are aggregate characteristics of students in each sector as well as institutional-level spending (a proxy for college quality). The resulting estimates, presented in Table 2, show how

\footnotetext{
${ }^{32}$ Note that in such a case our estimates still would identify the effect of labor demand shocks on CBSA-level outcomes as a function of for-profit supply, but they no longer would reflect the causal effect of an individual attending a for-profit institution.
} 
student characteristics and institutional spending in for-profits change relative to publics across the distribution of for-profit supply when there is a labor demand shock. We examine a wide range of outcomes: student racial/ethnic backgrounds, age, financial aid receipt, the number of colleges to which students sent a FAFSA, parental education, parental income, the academic achievement of the student body, the composition and types of degrees awarded 33 and shares and per pupil spending in various spending categories. Only two of the 64 estimates in the table is statistically significantly different from zero at the $5 \%$ level and two more are significant at the $10 \%$ level. These proportions of significant coefficients are what one would expect from random error if all effects were zero. Furthermore, the estimates are small in magnitude with inconsistent signs, suggesting that our instrument does not generate systematic relative shifts in the composition of students or spending across institution types in a manner that would bias our estimates. Our results are consistent with students sorting into different institutions in the same way where for-profit supply is high versus low, given a labor demand shock. That is, students do not sort differently into for-profit institutions when there is a negative labor demand shock in areas that have a higher pre-existing supply of for-profits. The results in Table 2 from the extensive set of observed characteristics in our data make it unlikely that our results are being driven by compositional shifts of students or spending shifts across institutions.

The null effects for changes in the types of degrees and majors in Table 2 are particularly important for interpreting our results below. For-profit and public postsecondary institutions can offer different degrees and can have different academic foci. This is not necessarily a problem for identification insofar as part of the causal effect of attending a given school is to obtain training in an area in which the school specializes. Table 2 shows that the marginal for-profit student faces the same degree and major composition as the marginal public student, which would not be the case if our instrument generated changes in the types of degrees and majors awarded. That we do not see changes in broad categories of majors or degree types suggests our results are not being driven by changes in the types of academic credentials students earn. Rather, we argue they reflect differences in the return to enrolling in a for-profit versus a public institution, holding fixed the type of academic credential being earned. As discussed above, the College Scorecard data are potentially problematic because they condition on receiving federal aid and do not account for differences in degree types across institutions. The results in Table 2 indicate that our estimates are unlikely to be affected by these data features, as the likelihood of receiving aid and the types of degrees students earn are not systematically related to our

\footnotetext{
${ }^{33}$ Descriptive statistics of these variables are shown in Online Appendix Table A-2.
} 
instrument.

The enrollment variation that identifies our estimates comes from two sources: students who otherwise would not have enrolled and students who otherwise would have enrolled in another sector. That is, our estimates reflect both changes in where students enroll (public vs. for-profit) and whether students enroll in a postsecondary institution. Our data do not allow us to analyze what proportion of affected students come from each group. This is an important limitation because if the set of compliers in each sector is different, our estimates of $\beta_{6}$ may confound any sector-specific treatment effect with differences in the composition of compliers. Table 2 provides direct evidence against this source of bias. We find that the relative composition of students is not changing due to variation in the instrument. That is, the instrument compliers are the same across sectors along a wide range of observed characteristics. Although it is possible that the complier sets are different among unobserved dimensions that relate to outcomes, the set of characteristics in Table 2 is extensive. It is very unlikely that differences in unobserved characteristics correlated with the outcomes of interest would arise without being detected by at least some of the variables included in the table. The results in Table 2 thus strongly support the assumption that our identifying variation is not altering the composition of students in a manner that would bias the comparison of marginal enrollment effects in the for-profit versus the public sector.

The parameter $\beta_{6}$ in equation (5) shows how adding an additional student to the for-profit sector affects outcomes relative to adding an additional student to the public sector. As long as the relative composition of marginal students nor relative institutional quality change due to variation in the instrument, our model identifies the marginal effect of attending a for-profit relative to a public institution. This parameter is of much interest because most public colleges we examine are relatively open access. Thus, students typically have the option of attending either a for-profit or a public college. The question of how for-profit attendance affects outcomes relative to non-attendance also is of interest, but our design does not lend itself to answering this question and thus we leave it for future study.

A final identification concern comes from two data issues: difficulty in observing online enrollment and the fact that only Title IV-granting institutions are included in the IPEDS data. Online institutions and enrollment have grown rapidly over the course of our analysis (Deming et al. 2016; Deming, Lovenheim and Patterson 2016). However, Online Appendix Table A-22 shows that our outcome data are predominantly from the mid-2000s, which is a period during which online enrollment was far lower than it is today. Furthermore, online enrollment is likely 
to weaken our first stage because it breaks the link between local labor demand shocks and local enrollment. Figure 1 shows that labor demand shocks are not spacially correlated, and so online enrollments from students outside of a given CBSA are unlikely to be correlated with labor demand conditions within that CBSA. Thus, other than weakening the first stage, we argue online enrollments are not a plausible source of bias in our estimates. We also show in Section 4.3 that our results are robust to dropping online institutions from the analysis and to using pre-2006 cohorts among which online enrollment was under $2 \%$. The fact that nonTitle-IV institutions are not well represented in IPEDS also is not likely to bias our estimates. The CBSA fixed effects account for fixed differences in the proportion of for-profits in the IPEDS data across areas. The main concern is that our instrument induces changes in Title IV status. We show in Section 4.4 that the number of for-profit institutions in the IPEDS data is uncorrelated with our instrument. These results suggest that our estimates are not driven by endogenous changes in the set of institutions in our data.

\section{Results}

\subsection{First Stage Estimates}

First-stage estimates for four-year and two-year institutions are shown in Table 3. In the interest of space, we show only the coefficients on the instruments: $\alpha_{6}$, which corresponds to the variable $\hat{\eta} *$ Supply $* F P$ and $\alpha_{2}$, which corresponds to the variable $\hat{\eta} *$ Supply. Odd columns contain results that include year fixed effects, and even columns include state-by-year fixed effects ${ }^{34}$ Panels A and B show results for four year institutions and are distinguished by the inclusion of state-by-for-profit and year-by-for-profit fixed effects in Panel B.

Focusing on the estimate on $\hat{\eta} *$ Supply $*$ FP in the 2000-2014 period, which is the main coefficient of interest, a 1 percentage point decline in labor demand increases enrollment in forprofits by 229.7 students when the proportion of enrollment in for-profits is 1 percentage point higher in 2000. The results change little when state-year, state-for-profit and year-for-profit fixed effects are added to the regression. Estimates in all columns are significant at the $1 \%$ level, and the P-value of the test that the coefficients on the instruments are zero are shown at the bottom of each panel. In all columns and panels, the null is rejected at very high levels of significance, indicating that our instruments are sufficiently strong.

These results are interesting in their own right because they suggest both that postsecondary

\footnotetext{
${ }^{34}$ Recall that all estimates include CBSA fixed effects, which subsume state fixed effects in the odd columns.
} 
enrollment is strongly related to local labor demand changes and that the types of institutions in which students enroll because of reduced labor demand is influenced by the latent supply of schools 35 When there are more for-profit institutions, students are more likely to sort into those schools when a recession hits the local area. The estimates in Table 3 underscore the importance of for-profit institutions in worker training during recessions. To the extent that there are causal effects of college choice on student outcomes, it suggests that latent supply of postsecondary institutions can affect the dynamics of how local areas recover from recessions.

In the subsequent columns of Table 3, we examine estimates from 2000-2006 and from 20082014. The first time period corresponds to relatively strong labor demand, while the later period contains the great recession. The effect is larger in the 2008-2014 time period, but enrollment responsiveness to labor demand shocks as a function of for-profit supply is economically and statistically significant prior to the great recession as well.

Panels C and D of Table 3 present similar estimates for two-year and less-than-two-year institutions. Although the levels differ from the four-year estimates because four-year institutions are larger, the patterns are almost identical. In the 2000-14 period, a 1 percentage point reduction in labor demand increases enrollment by 104.5 students in the for-profit sector for every 1 percentage point increase in baseline for-profit supply. These estimates change little with the inclusion of state-by-year, state-by-for-profit and year-by-for-profit fixed effects, and the instruments are sufficiently powered. Unlike in four-year institutions, the effect is larger in the 2000-2006 period than in the 2008-2014 period. This difference may be driven in part by the relatively large growth in four-year for-profits during the later period. The estimates indicate that students are highly responsive to labor demand changes and to higher education supply in their postsecondary enrollment choices in both periods and in both types of institutions (four-year and two-year).

Also of interest in Table 3 is the coefficient on $\hat{\eta} *$ Supply, corresponding to $\alpha_{2}$ in equation (4). These estimates show that public enrollment declines for a given labor demand shock when the for-profit share is higher, although the effect is much weaker among 4-year schools. This occurs because students are more likely to sort into for-profit schools in these areas due to the labor demand decline. Across columns in Table 3, all estimates are positive and are statistically significant at the $1 \%$ level in the two-year sector results. We consistently find that

\footnotetext{
${ }^{35}$ These results are consistent with prior research showing that students are very willing to substitute across the public and forprofit sectors. Goodman and Henriques (2016) demonstrate that reductions in state appropriations induce students to substitute from the public to the for-profit sector. Cellini, Darolia and Turner (2016) find that when for-profits lost the ability to disperse Title IV financial aid, students substituted to the public sector such that overall enrollment rates did not decline. The results in Table 3 also indicate that there is a good deal of substitution across the public and for-profit sectors and that the degree of substitution is related to the higher education supply conditions.
} 
$\left|\alpha_{2}\right|<\left|\alpha_{6}\right|$, which implies that overall postsecondary enrollment grows when there is a negative demand shock in areas that have higher baseline for-profit supply. This result is consistent with for-profits reducing capacity constraints in local postsecondary markets. That higher forprofit supply leads to higher overall enrollment when there is a negative labor demand shock underscores concerns that the composition of students also is changing. However, in Table 2 we show this is not the case: students sort in the same manner into for-profit and public institutions due to demand shocks across the distribution of 2000 for-profit supply. Thus, changes to the composition of students are unlikely to bias our estimates of the relative effects of an enrollment increase in the for-profit versus the public sector.

One objection to the four-year estimates in Table 3 is the inclusion of selective colleges and universities. These institutions do not take most of their enrollments from local areas, and they do not face much (or any) competition from the for-profit sector. In Appendix Table A-8, we show first-stage estimates that exclude any colleges and universities that have a rating of "Highly Competitive" or higher in the 2001 Barrons rankings. We perform this robustness check only among four-year schools as two-year institutions do not practice selective admissions. The estimates are extremely similar to those in Table 3 and in some cases are more precisely estimated. Thus, inclusion of selective schools does not drive our enrollment results.

Our baseline estimates in Table 3 use total 12-month enrollment. There are several enrollment measures we could use instead, including 12 month undergraduate enrollment and various fall enrollment measures such as undergraduate enrollment, full-time enrollment and first-time enrollment. Figure 8 shows first-stage estimates of $\alpha_{6}$ from equation (4) using different enrollment measures. Although the estimates differ somewhat in magnitude due to different baseline levels, all estimates are economically meaningful in magnitude and are statistically significant at the $1 \%$ level both among four-year and two-year institutions. Figure 8 demonstrates that our results are not sensitive to the specific way in which we measure student enrollment ${ }^{36}$

\subsection{Second Stage Estimates}

Tables 4-7 present second-stage estimates of $\beta_{5}$ and $\beta_{6}$ from equation (5) for our outcomes of interest. These estimates show the effect of adding an additional student to the public sector $\left(\beta_{5}\right)$ and the incremental effect of adding an additional student to the for-profit sector relative to the public sector $\left(\beta_{6}\right)$. Thus, they can be interpreted as the marginal effect of an additional enrollment in either sector. In Tables 4-6, we present results separately including year (columns

\footnotetext{
${ }^{36}$ Estimates of equation (4) using these various enrollment measures are available from the authors upon request.
} 
1-2 and 5-6) and state-by-year (columns 3-4 and 7-8) fixed effects. Even columns include stateby-for-profit and year-by-for-profit fixed effects. Estimates are shown separately for four-year (columns 1-4) and two-year (columns 5-8) schools. In Table 7, to conserve space we only present results that include state-by-year fixed effects. Even columns continue to include state-by-forprofit and year-by-for-profit fixed effects. Estimates for four-year schools are in columns 1-2 while those for two-year schools are in columns 3-4.

Table 4 presents our main second stage results on borrowing and default. Panel A shows estimates for total number of loans originated. Among four-year students, there is a consistent positive effect for $\beta_{6}$ across columns that is significant at the $1 \%$ level. While a marginal public student originates 0.4-0.5 loans, a marginal for-profit enrollee originates 1.1 more loans than her counterpart in a public college or university. Estimates for $\beta_{6}$ among two-year students are similar in magnitude though less precise. Relative to the number of loans taken out by the marginal public student, these increases for the marginal for-profit student are substantial. It could be the case that these results reflect students taking out a larger number of smaller loans, and so in Panel B we present estimates of total loan origination amount. The results demonstrate that for-profit enrollment in both the four-year and two-year sectors leads students to take on more loan debt. A marginal four-year for-profit student originates $\$ 3,356$ more in student loans than her public sector counterpart, and a marginal two-year student originates $\$ 6,428$ more in student loans than a comparable student in the public sector. Thus, not only are for-profit students taking on a larger number of loans, they are taking on a larger volume of student debt. These estimates are consistent with prior results showing higher loan volumes among for-profit students (e.g., Deming, Goldin and Katz 2012; Liu and Belfield 2014a; ScottClayton 2018; Cellini and Darolia 2016), though as previously discussed they are based on an identification strategy that we argue more credibly addresses selection on unobservables.

In Table 5, we unpack the loan estimates further by examining the effect of for-profit enrollment on the number of loan recipients by student loan type. Unlike the estimates for total number of loans (Table 4 Panel A), these results show how for-profit enrollment affects the propensity to originate each type of loan. In particular, the extent to which students are taking out subsidized versus unsubsidized loans is important for understanding both the private and social cost of different enrollment choices. Four-year for-profit enrollment leads to a markedly higher likelihood of originating each type of student loan. Panel A shows that a marginal for-profit enrollee is 61-69 percentage points more likely to take out a direct subsidized loan than her public counterpart. Panels B, C, and D show that for-profit enrollment in four-year 
schools increases the propensity of originating a direct unsubsidized loan, a FFEL subsidized loan and FFEL unsubsidized loan by 61, 48, and 42 percentage points, respectively. Examining results across columns shows the estimates are robust to the addition of various fixed effects we include in the regressions. Estimates for two-year students are economically smaller and are less precise. Overall, Tables 4 and 5 show that four-year for-profit students rely much more heavily on federal loans (including subsidized loans) relative to public students: a marginal four-year for-profit enrollee has more than a $95 \%$ probability of originating a direct subsidized loan, whereas her public counterpart has only a 33-35\% probability of originating such a loan.

Does this added debt burden increase the likelihood of default? Panel $\mathrm{C}$ of Table 4 shows effects on student loan defaults. Among four-year students, the results indicate that for-profit enrollment increases the likelihood of default by about 11 percentage points. These estimates are statistically different from zero at the 1 percent level and indicate that the increased loan burden associated with for-profit schools leads to a substantially higher risk of default. In the two-year schools, the estimates are even larger, at 21 percentage points. The effects are significant at the $10 \%$ level when only using year fixed effects but become imprecise when stateyear fixed effects are included in the model. However, these estimates are suggestive of much higher default among marginal two-year for-profit students.

There are two non-mutually-exclusive reasons why for-profit enrollment increases the likelihood of loan default. The first is that for-profit institutions have higher tuition, which leads to higher debt burdens. Panel A of Table 6 shows how total tuition dollars paid by in-state students increase when enrollment in each sector increases by one student, which is effectively the average in-state tuition price paid by the marginal student. Tuition paid by marginal for-profit students is $\$ 6,000-\$ 7,500$ higher among four-year entrants and is over $\$ 9,000$ higher among marginal two-year college students relative to their public counterparts. These higher tuition prices are consistent with (and are likely a driver of) the higher loan originations by both four-year and two-year for-profit students seen in Table 4. Indeed, the larger for-profit tuition effect among two-year students is reflected in a larger two-year loan origination effect (\$6428 for two-year versus $\$ 3356$ for four-year for-profit students). Our results thus suggest that students attending for-profits take on more loan debt because they face higher statutory tuition levels. That tuition prices paid by the marginal for-profit student is much higher than the price paid by the marginal public student has been well documented in the popular press and in prior research (Deming, Goldin and Katz 2012), but this is the first evidence showing that these tuition differences lead to higher loan originations (and defaults). 
The higher tuition levels faced by for-profit students are not driven by changes in tuition from the enrollment demand shocks that form the basis of our identifying variation. Panel B of Table 6 examines how average tuition payments vary with additional enrollment in each sector. We see no evidence that attending a for-profit college is associated with higher average tuition. This implies that the enrollment demand increases stemming from our instrument do not generate changes in tuition prices. While prior work has shown that for-profit colleges set tuition in response to federal aid levels (Cellini and Goldin 2014), Table 6 shows they do not do so in response to increases in enrollment demand when there are negative labor market shocks.

The second reason loan default rates are higher among for-profit students is that they may be less likely to graduate and have worse labor market outcomes. Table 7 reports results for these outcomes; for brevity we only show estimates that include state-by-year fixed effects. In Panel A, we show that four-year for-profit students are somewhat less likely to graduate than their public counterparts, although the estimates are not statistically different from zero at conventional levels. Among two-year students, there is evidence that for-profit schools are more adept at graduating students: an additional enrollment is associated with 0.28 additional students graduating. While not statistically significant, these results suggest that enrolling in a two-year for-profit institution increases the likelihood of degree receipt substantially ${ }^{37}$

Looking past postsecondary outcomes, the remaining panels of Table 7 examine the labor market returns to for-profit enrollment relative to public enrollment. Recall from Section 2.2 that the labor market outcomes are only for those who received federal financial aid. In Table 2, we do not find an economically (or statistically) significant relationship between the instrument and the percentage receiving federal aid. This suggests there is no differential selection in our labor market sample by federal financial aid receipt that would bias our estimates. Nonetheless, it is important to highlight that the labor market results hold only for federal aid recipients.

Panel B of Table 7 shows that four-year for-profit enrollment reduces the likelihood of employment by 11 percentage points while two-year for-profit enrollment reduces the likelihood of employment by 36 percentage points. However, the two-year estimates are not statistically significant. Panel C shows that earnings are lower for both four-year and two-year for-profit students relative to their public counterparts, but the estimates are imprecise. A marginal four-year for-profit student earns about $\$ 6,000$ less than her public counterpart six years after enrolling. For two-year students, the earnings penalty for for-profit enrollment is about $\$ 9,000$.

\footnotetext{
${ }^{37}$ Deming, Goldin and Katz (2012) and Liu and Belfield (2014a) also find evidence that for-profit students are more likely to graduate than their public counterparts.
} 
In both sectors, earnings reductions are large relative to the Enroll estimates, which can be interpreted as the earnings of a marginal public postsecondary student.

Estimates in Panel D show less consistent results across sectors for the likelihood of earning more than $\$ 25,000$ per year. The threshold of $\$ 25,000$ is of interest as it corresponds approximately to the median wage of workers aged 25 to 34 with only a high-school degree. Examining this outcome helps gauge whether students are better off from having decided to enroll in a for-profit (or public) college rather than not invest in a postsecondary degree. The likelihood a marginal four-year public college student earns over $\$ 25,000$ is 71 percent. Four-year for-profit students are about 8 percentage points (or 11\%) less likely than their public counterparts to earn over this amount, but the estimates are not precise. Among two-year students, the results indicate an increased likelihood of earning over $\$ 25,000$, but they also are imprecise. In both the two-year and four-year sectors, marginal students are substantially more likely to earn over $\$ 25,000$ per year, which suggests a positive gross return to investing in a postsecondary education (both for-profit and public).

Taken together, the results in Tables 4-7 indicate that four-year for-profit enrollment leads to higher likelihood of borrowing, larger debt originations, higher default, and worse labor market outcomes. The results among two-year students are less clear, but we do find evidence that these students are more likely to graduate, take on more debt, and are more likely to default. Despite their higher debt and the higher likelihood of degree receipt, our estimates suggest these students have worse labor market outcomes than community college students. The evidence thus indicates the return to these degrees is rather low. Among four-year institutions, our results strongly suggest the return to for-profit enrollment relative to public four-year enrollment is negative. Students could earn more, take on less debt, default at lower rates, and be more likely to graduate if they attended a public four-year institution.

How do the IV estimates relate to those from OLS models that control for the same fixed effects and observed characteristics? Online Appendix Tables A-4 through A-6 present OLS results for our outcomes of interest. The estimates are qualitatively similar to those in Tables 4, 5 and 7, but as expected they are more precise. The two-year OLS results generally paint a more negative picture of for-profit attendance on both labor market and loan outcomes, potentially because of negative selection into these for-profit schools. The four-year for-profit OLS estimates also are qualitatively similar to the IV results but tend to indicate less of an adverse effect on student outcomes. The differences in magnitudes between the OLS and IV estimates may be due to a variety of factors, such as differences in student selection across 
schools, differences in local labor markets, differences in school locations, and funding, as well as any interactions between these factors. Importantly, our IV estimates also capture a local average treatment effect driven in part by labor-demand induced changes in enrollment. OLS estimates, in addition to not being causal, incorporate all enrollment variation.

\subsection{Robustness Checks}

In this section, we present a series of robustness checks that probe the sensitivity of our findings ${ }^{38}$ A core identification concern in our analysis relates to serial correlation in the labor demand shock. We control for $\hat{\eta}_{t-1}$ directly in our regressions, but if any serial correlation in predicted labor demand is correlated with for-profit supply heterogeneity, then it could cause a bias in our estimates if it also is correlated with secular trends in our outcomes of interest. We perform robustness checks in which we control for leads of labor demand shocks to provide evidence that this source of bias is not present in our setting. In Table 8, we show results for our main outcomes of interest in which we control for $\hat{\eta}_{t}$ and $\hat{\eta}_{t+1}$. Results are very similar to baseline. In results not reported here to save space (but available on request), we find that results also remain very similar if we control for one lead of our labor demand shock $\left(\hat{\eta}_{t}\right)$. These estimates indicate that serial correlation in the instrument is not biasing our results.

IPEDS (the source of our institutional classification data) defines four-year institutions as institutions that grant at least one Bachelor's degree. Many universities have a mix of twoand four-year degree programs, and as shown in Table A-2, the proportion of Bachelors degrees in for-profit four-years is lower than among public four-years. Table 9 explores the sensitivity of our results to different degree compositions of public and for-profit four-year institutions. Specifically, we investigate whether our results remain similar when we restrict our sample to public and for-profit institutions that have similar degree compositions. The first four columns show estimates in which we classify four-year schools as those with at least $25 \%$ of their degrees as Bachelors in 2000. In columns (5)-(8), we define schools above the 25th percentile of the Bachelors degree distribution in 2000 as four-year schools. Note that the number of observations changes little because the observation counts are at the sector-CBSA-year level rather than at the institutional level. The estimates in Table 9 are very similar to those shown previously, with two minor differences. First, the loan origination estimates are somewhat smaller and are not statistically significant in columns (1)-(2). But, they are qualitatively similar. Estimates

\footnotetext{
${ }^{38}$ For sake of brevity we do not report first stage estimates for most robustness checks. In no case does the first stage estimates change substantively; these estimates are available from the authors upon request.
} 
in columns (5)-(8) match those in Table 4 quite closely in terms of magnitude and statistical significance. Second, the employment estimates are larger in absolute value, indicating that the for-profit enrollee is between 13-14\% less likely to be employed than her public counterpart six years after enrollment.

One might be concerned that $25 \%$ of Bachelors degrees is too low a place in the distribution to cut the sample. In Online Appendix Table A-15 columns (1)-(4) and (5)-(8) respectively, we define four-year institutions as institutions where (a) 25-50\% of the degrees awarded were Bachelors Degrees in 2000 and (b) at least $75 \%$ of the degrees awarded were Bachelors. The results for the $25-50 \%$ group are very similar to the results in Table 9 . The estimates are slightly smaller (in absolute value) among the $75 \%+$ Bachelors institutions for the number of loans and loan origination amounts. But, they are larger (in absolute value) for the percent employed, indicating that the marginal for-profit enrollee is between 18-21\% less likely to be employed than the public enrollee. In all cases the estimates using state-year fixed effects are within the 95\% confidence intervals of the baseline results. Overall, we find little evidence of heterogeneity as the percent of Bachelors Degrees awarded increases among four-year institutions.

Rather than splitting the sample by the percentage of Bachelors degrees awarded, we can instead directly control for degree composition of schools. Since degree composition can potentially be endogenous, we instead control for interactions between baseline (2000) degree composition and year fixed effects. Online Appendix Tables A-12 through A-14 include controls for percent certificates awarded in 2000 interacted with year indicators for the two-year sample and percent Bachelor's degrees awarded in 2000 interacted with year indicators for the four-year sample. The results accord very closely with those shown in Tables 4, 5 and 7 in sign, magnitude and statistical significance. These results, combined with those in Table 2, Table 9 and Table A-15, suggest that we are not simply picking up a mechanical effect of different degree types across institutions. We find no evidence of a change in the mix of degrees awarded (Table 2 ), little heterogeneity in effects when we restrict the sample to compare between institutions awarding like degrees in the four-year sector, and directly controlling for degree composition of the college leaves results virtually unchanged.

Although we do not find that our instruments generate changes in the composition of students along observed dimensions, there is a potential concern about switching across the twoyear/four-year margin given that our models are level-specific. In Online Appendix Table A-16, we show estimates that include opposite-level supply controls interacted with the for-profit indicator and labor demand shocks. That is, in the four-year sector estimates we control for 
two-year baseline supply fully interacted with FP and $\hat{\eta}$ (and vice versa). These controls are not used as additional instruments but rather to account for the fact that the instruments are likely to be highly correlated across institutional levels so that not controlling for the other level may introduce an omitted variable bias driven by cross-level switching. The estimates are very similar to baseline in magnitude, sign, and statistical significance, with the exception of the employment estimates that are no longer statistically significant in the four-year results. However, they are qualitatively similar. These results suggest that the level-specific approach we take does not drive our results.

As discussed previously, some of the enrollment variation that identifies our estimates comes from students who otherwise would not have enrolled. If entry of for-profits is larger in areas with more postsecondary demand and if trends in the size of the college-age population drive both for-profit entry and relative enrollment, it could introduce a bias in our estimates. In Online Appendix Table A-17, we show results from a model that includes a quadratic in the size of the college-age population in each year and CBSA. In effect, this model accounts for any bias driven by the correlation of our instrument with underlying changes in the demand for college-going that are induced by population changes rather than labor market shocks 39 The results align closely with our baseline estimates.

An additional concern is that our instrument may be correlated with changes in state appropriations, which form a large component of total resources for most public universities. In results available upon request, we controlled for state appropriations per student and the results and conclusions are unchanged.

Our identification strategy relies on local postsecondary enrollment, which means online options can generate bias if the online enrollment is coming differentially from areas with higher for-profit supply, given labor demand. We exclude online colleges and universities from our analysis in Online Appendix Table A-1940 Despite the substantial growth in the online postsecondary sector during this period, the point estimates change little from baseline. The one exception is that the employment estimates in the four-year results are larger in absolute value indicating larger negative effect of for-profit attendance, but they also are imprecise such

\footnotetext{
${ }^{39}$ Bound and Turner (2007) and Bound, Lovenheim and Turner (2010) show that the size of the college-age population has large effects on enrollment in less-selective institutions.

${ }^{40}$ We use the IPEDS definition of a fully online institution (where all programs are offered via distance education), which it began reporting in 2011. We exclude from the entire analysis sample the 60 institutions that were listed as fully online between 2011 and 2014. Using the method in Deming, Goldin and Katz (2012) that employs a threshold for out-of-state enrollment share yields similar results. IPEDS also reports an alternative measure that identifies schools that offer only some programs or courses (but not all) via distance education. We do not use this measure as a large part of the enrollment of these "some online" schools comes from local enrollment. Excluding these schools would lead us to exclude much of our relevant local enrollment variation. The local average treatment effects we estimate are driven by the local students whose enrollment decisions are influenced by exposure to local labor demand shocks and postsecondary supply conditions.
} 
that the $95 \%$ confidence interval includes the preferred estimate.

Online education expanded dramatically after 2006 due to the elimination of the Federal $50 \%$ rule that required less than half of students be involved in "distance learning" for colleges to be eligible to disburse Title IV aid. Prior to 2006, less than $2 \%$ of enrollment was in online programs (Deming, Lovenheim and Patterson 2016). Taking advantage of this differences in size of the online sector, we present four-year estimates in Table A-20 where we restrict our sample to pre-2007 and pre-2006 entry cohorts when the size of the online sector was small. The estimates using this earlier, pre-online period are very similar to baseline, suggesting our main results are not biased by the rise in online degree programs.

As previously discussed, we also exclude selective institutions that have an admissions selectivity rating of Highly Competitive or higher in the 2001 Barrons rankings. The first-stage and second-stage estimates shown in Appendix Tables A-8 through A-11 are very similar to those shown above. Taken together, these results all indicate that our main estimates are robust to the specific modeling and data assumptions we make.

\subsection{For-Profit Entry and Exit}

One of the mechanisms underlying our results could be entry or exit of for-profit (or public) schools in response to changes in labor demand, especially if such entry/exit is differentially responsive in areas with higher for-profit supply. To the extent that new for-profit entrants are less productive, this could drive some of the worse outcomes we find among for-profit students. In Table 10, we examine how for-profit and public entry respond to labor demand changes. Panel A shows there is at most a small relationship between predicted labor demand shocks and entry/exit of schools. Among four-year institutions, a 1 percentage point decrease in labor demand leads to 0.02 more for-profit schools. These estimates are significant at the $10 \%$ level or higher and are equivalent to only a $3 \%$ increase in for-profit institutions. Among two-year schools, labor demand shocks increase the number of for-profits by 0.02 , which is equivalent to a $0.6 \%$ increase. However, this result is not robust to the inclusion of state-year fixed effects.

The results in Panel B examine entry behavior in response to labor demand shocks differentially by pre-existing for-profit supply. It could be the case that areas with higher for-profit supply are more amenable to for-profit schools, in which case entry would be even higher in areas with a higher for-profit supply in 2000 when there is a labor demand decrease. It also

could be the case that variation in the instrument generates changes in Title IV status. Among four-year institutions, there is little evidence that this is the case: the effect of a negative labor 
demand shock on entry is not different in areas that had a larger share of for-profit institutions in 2000. We do find that two-year for-profits are slightly more likely to enter in areas in which they were more prevalent in 2000 due to a negative labor demand shock, however the estimate is quite small. Given a 1 percentage point labor demand shock, a 1 percentage point higher for-profit supply leads to 0.001 more for-profit schools, which is equivalent to a $0.03 \%$ increase. The estimate is only significant at the $10 \%$ level. Investigating these effects by sub-periods, we find that the two-year for-profit entry effect is entirely coming from the 2008-14 period. We continue to find no evidence of differential four-year for-profit entry by latent supply in the sub-periods, given a labor demand shock. These results are presented in Online Appendix Table A-21. As Online Appendix Table A-22 shows, the 2008-14 period is after most of the cohorts are enrolled for which we observe the outcomes of interest. The timing of two-year for-profit entry response to labor demand shocks (in higher baseline supply areas) thus does not align with the period when the outcomes on which we focus are measured and hence are unlikely to affect our results.

The results in Table 10 are important because little currently is known about the for-profit entry decision. Our estimates indicate that for-profit institutions are somewhat responsive to labor-market driven demand, although they can only explain a very small portion of entry behavior. Because the entry/exit effects are so small, our estimates are unlikely to be influenced by changes in the composition of for-profit colleges in an area. Entry effects hence are unlikely to be a core mechanism underlying our results.

\section{Conclusion}

For-profit providers are becoming an increasingly important fixture of the higher education landscape. These institutions are controversial because they are more expensive to attend, students who attend them take on more debt and default at higher rates, and post-enrollment earnings of for-profit attendees is lower. Because students select into colleges based on factors that are difficult to observe and that correlate with future outcomes, one cannot interpret the negative correlation between for-profit attendance and student outcomes as evidence of a negative causal effect relative to attending a public college or university. For-profit institutions may be more responsive to student demand and to the needs of the local labor market, so it also is possible that returns to investing in this type of school are positive. These arguments underscore the importance of identifying the return to for-profit enrollment. 
The research to date on the returns to for-profit postsecondary attendance looks at a limited set of outcomes and/or faces serious challenges overcoming the selection of students into different higher education sectors. We contribute to the literature by using a novel instrument that more credibly overcomes the selection problem than prior work using observational data, and we provide a more comprehensive analysis of the return to for-profit enrollment using several administrative datasources that have not previously been brought to bear on this question. Our approach to overcoming the selection problem is to exploit predicted labor demand changes using the shift-share instrument first introduced by Bartik (1991) combined with the pre-existing supply of for-profit institutions in a CBSA. The idea underlying our approach is that negative labor demand shocks increase the demand for postsecondary enrollment (and vice versa), and a substantial proportion of students induced to attend when labor demand is low will go to local schools. We compare enrollment and student outcomes across CBSAs that experience the same labor demand shock in a given year but that have different for-profit supply in our base year (2000). Our estimates strongly support the conclusion that students are more likely to sort into for-profit schools due to a labor demand shock when there are more such schools in the area in 2000. These results are interesting in their own right because they show that in many areas the for-profit sector is an important component of worker training during recessions.

Using predicted labor demand shocks interacted with 2000 for-profit supply as an instrument for for-profit enrollment, we estimate the causal effect of for-profit enrollment relative to enrolling in a public college on a large set of financial aid, educational and labor market outcomes: propensity to borrow, number of loans originated, loan amounts, loan default, graduation, employment and earnings. We do the analysis separately for four-year and two-year institutions as well. The four-year estimates point consistently to negative effects of enrolling in a for-profit college on student outcomes. Relative to their public counterparts, enrolling in a for-profit institution increases the number of loans by one, increases the size of loans originated by over $\$ 3,300$, and leads to an 11 percentage point increase in the likelihood of loan default. There is some evidence for-profit students are less likely to graduate and that they have substantially worse labor market outcomes as well.

Estimates among two-year and less-than-two-year students are less precisely estimated but are consistent with worse outcomes among for-profit students. These students take out more loans, originate over $\$ 6,000$ more in loans, and are much more likely to default. They also experience lower likelihoods of employment and lower earnings on average, but they are more likely to earn over $\$ 25,000$ (the median earnings of high school graduates). Interestingly, these 
for-profit students appear more likely to graduate than community college students, which suggests that the return to obtaining sub-baccalaureate for-profit degrees is particularly low. Our estimates identify a (local) average treatment effect of for-profit enrollment, but we are unable to determine what properties of for-profit colleges are associated with more versus less productivity. We plan to examine this important question in subsequent research.

Overall, our results indicate that, on average, for-profit enrollment leads to worse outcomes for students than enrolling in a public college or university. This is an important set of findings for several reasons. First, a substantial amount of public funds go to for-profit institutions through the financial aid system. Our estimates indicate the return to such expenditures may be quite low. Second, the results suggest that students who attend local postsecondary institutions when there is a negative labor demand shock may be making mistakes: they would be better off attending the local public college or university instead. This highlights the potentially important role for providing such students with more information to help support them in making more informed choices. Exactly how to provide such information to students and what effects it will have on enrollment decisions is an important set of questions for future research.

\section{References}

[1] Aguiar, Mark, Erik Hurst and Loukas Karabarbounis. 2013. "Time Use During the Great Recession." American Economic Review 103(5): 1664-1696.

[2] Andrews, Rodney J., Jing Li and Michael F. Lovenheim. 2016. "Quantile Treatment Effects of College Quality on Earnings." Journal of Human Resources 51(1): 200-238.

[3] Arcidiacono, Peter and Michael F. Lovenheim. 2016. "Affirmative Action and the Quality-Fit Tradeoff." Journal of Economic Literature 54(1): 3-51.

[4] Autor, David H. and Mark G. Duggan. 2003. "The Rise in the Disability Rolls and the Decline in Unemployment." Quarterly Journal of Economics 118(1): 157-205.

[5] Bartik, Timothy J. 1991. "Who Benefits from State and Local Development Policies?" Upjohn Institute for Employment Research: Kalamazoo, MI.

[6] Barr, Andrew, 2015. "From the Battlefield to the Schoolyard: The Short- Term Impact of the Post-9/11 GI Bill." Journal of Human Resources 50(3): 580-613.

[7] Becker, Gary S. 1962. "Investment in Human Capital: A Theoretical Analysis." Journal of Political Economy 70(5), Part 2: 9-49.

[8] Betts, Julian R. and Laurel L. McFarland. 1995. "Safe Port in a Storm: The Impact of Labor Market Conditions on Community College Enrollments." Journal of Human Resources 30(4): 741-765. 
[9] Black, Dan A. and Jeffrey A. Smith. 2004. "How Robust is the Evidence on the Effects of College Quality? Evidence from Matching." Journal of Econometrics 121(1-2): 99-124.

[10] Black, Dan A. and Jeffrey A. Smith. 2006. "Estimating the Returns to College Quality with Multiple Proxies for Quality." Journal of Labor Economics 24(3): 701-728.

[11] Borusyak, Kirill, Peter Hull, and Xavier Jaravel. 2018. "Quasi-experimental Shift-share Research Designs." NBER Working Paper No. 24997.

[12] Bound, John, Michael F. Lovenheim and Sarah E. Turner. 2010. "Why Have College Completion Rates Declined? An Analysis of Changing Student Preparation and Collegiate Resources." American Economic Journal: Applied Economics 2(3): 129-157.

[13] Bound, John and Sarah E. Turner. 2007. "Cohort Crowding: How Resources Affect Collegiate Attainment." Journal of Public Economics 91(5-6): 877-899.

[14] Brewer, Dominik, Eric Eide and Ronald Ehrenberg, 1999. "Does it Pay to Attend an Elite Private College? Cross-Cohort Evidence on the Effects of College Type on Earnings." Journal of Human Resources 34(1): 104-123.

[15] Card, David. 1995. "Using Geographic Variation in College Proximity to Estimate the Return to Schooling. In Aspects of Labor Market Behaviour: Essays in Honour of John Vanderkamp, edited by L. N. Christofides, E. K. Grant, and R. Swidinsky. Toronto: University of Toronto Press.

[16] Chakrabarti, Rajashri, Michael Lovenheim and Kevin Morris, 2016a. "Who falters at student loan payback time?" Federal Reserve Bank of New York Liberty Street Economics (blog), September 9.

[17] Chakrabarti, Rajashri, Michael Lovenheim and Kevin Morris, 2016b. "Who Contributed to the Enrollment Bulge? The Changing Face of the Higher Education Market" Federal Reserve Bank of New York Liberty Street Economics (blog), September 7.

[18] Christian, Michael S. 2007. "Liquidity Constraints and the Cyclicality of College Enrollment in the United States." Oxford Economic Papers 59(1): 141-169.

[19] Cellini, Stephanie Riegg and Latika Chaudhary. 2014. "The Labor Market Returns to a For-profit College Education." Economics of Education Review 43: 125-140.

[20] Cellini, Stephanie Riegg and Claudia Goldin. 2014. "Does Federal Student Aid Raise Tuition? New Evidence on For-Profit Colleges." American Economic Journal: Economic Policy 6(4): 174-206.

[21] Cellini, Stephanie Riegg and Nicholas Turner. 2016. "Gainfully Employed? Assessing the Employment and Earnings of For-Profit College Students Using Administrative Data." NBER Working Paper No. 22287.

[22] Cellini, Stephanie Riegg and Rajeev Darolia. 2016. "Different Degrees of Debt: Student Borrowing in the For-Profit, Nonprofit, and Public Sectors." Brookings Report. 
https://www.brookings.edu/research/different-degrees-of-debt-studentborrowing-

in-the-for-profitnonprofit-and-public-sectors/.

[23] Cellini, Stephanie Riegg, Rajeev Darolia and Lesley J. Turner. 2016. "Where Do Students Go when ForProfit Colleges Lose Federal Aid?" NBER Working Paper No. 22967.

[24] Clark, Damon. 2011. "Do Recessions Keep Students in School? The Impact of Youth Unemployment on Enrolment in Post-compulsory Education in England." Economica 78: 523-545.

[25] Currie, Janet and Enrico Moretti. 2003. "Mother's Education and the Intergenerational Transmission of Human Capital: Evidence from College Openings." Quarterly Journal of Economics 118(4): 1495-1532.

[26] Dale, Stacey Berg and Alan B. Krueger. 2002. "Estimating the Payoff to Attending A More Selective College: An Application of Selection on Observables and Unobservables." Quarterly Journal of Economics 117(4): 1491-1527.

[27] Darolia, Rajeev. 2013. "Integrity Versus Access? The Effect of Federal Financial Aid Availability on Postsecondary Enrollment." Journal of Public Economics 106: 101-114.

[28] Darolia, Rajeev, Cory Koedel, Paco Martorell, Katie Wilson, and Francisco Perez-Arce. 2015. "Do Employers Prefer Workers Who Attend For-Profit Colleges? Evidence from a Field Experiment" Journal of Policy Analysis and Management 34(4): 881-903.

[29] Deming, David J., Claudia Goldin and Lawrence F. Katz. 2012. "The For-Profit Postsecondary School Sector: Nimble Critters or Agile Predators?" Journal of Economic Perspectives 26(1): 139-163.

[30] Deming, David J., Claudia Goldin and Lawrence F. Katz. 2013. "For-profit Colleges." The Future of Children 23(1): 137-163.

[31] Deming, David J., Michael Lovenheim and Richard Patterson. 2016. "The Competitive Effects of Online Education." NBER Working Paper No. 22749.

[32] Deming, David J., Noam Yuchtman, Amira Abulafi, Claudia Goldin and Lawrence F. Katz. 2016. "The Value of Postsecondary Credentials in the Labor Market: An Experimental Study." American Economic Review 106(3): 778-806.

[33] Denice, Patrick. 2015. "Does It Pay to Attend a For-Profit College? Vertical and Horizontal Stratification in Higher Education." Social Science Research 52: 161-178.

[34] Gilpin, Gregory A., Joseph Saunders and Christiana Stoddard. 2015. "Why Has For-profit Colleges' Share of Higher Education Expanded so Rapidly? Estimating the Responsiveness to Labor Market Changes." Economics of Education Review 45: 53-63.

[35] Goldsmith-Pinkham, Paul, Isaac Sorkin and Henry Swift. 2018. "Bartik Instruments: What, When, Why, and How." NBER Working Paper No. 24408. 
[36] Goodman, Sarena and Alice Henriques. 2016. "Attendance Spillovers between Public and For-Profit Colleges: Evidence from Statewide Variation in Appropriations for Higher Education." Mimeo.

[37] Heckman, James J. 1998. "Detecting Discrimination." Journal of Economic Perspectives 12.2: 101-116.

[38] Hershbein, Bradley J. 2012. "Graduating High School in a Recession: Work, Education, and Home Production." B.E. Journal of Economic Analysis 83 Policy 12(1): 1-30.

[39] Hoekstra, Mark. 2009. "The Effect of Attending the State Flagship University on Earnings: A DiscontinuityBased Approach." Review of Economics and Statistics 91(4): 717-724.

[40] Hoxby, Caroline M. 2009. "The Changing Selectivity of American Colleges." Journal of Economic Perspectives 23(4): 95-118.

[41] Hoxby, Caroline M. 2014. "The Economics of Online Postsecondary Education: MOOCs, Nonselective Education, and Highly Selective Education." American Economic Review: Papers and Proceedings 104(5): $528-533$.

[42] Hoxby, Caroline and Christopher Avery. 2013. "The Missing "One-Offs": The Hidden Supply of HighAchieving, Low-Income Students." Brookings Papers on Economic Activity Spring: 1-50.

[43] Hoxby, Caroline and Sarah Turner. 2013. "Expanding College Opportunities for High-achieving, Low Income Students." Stanford Institute for Economic Policy Research Discussion Paper 12-014.

[44] Jacobson, Louis, Robert LaLonde, and Daniel G. Sullivan. 2005. "Estimating the Returns to Community College Schooling for Displaced Workers." Journal of Econometrics 125(1-2): 271-304.

[45] Jepsen, Christopher, Kenneth Troske and Paul Coomes. 2014. "The Labor-Market Returns to Community College Degrees, Diplomas, and Certificates." Journal of Labor Economics 32(1): 95-121.

[46] Jepsen, Christopher, Peter Mueser, and Kyung-Seong Jeon. 2016. "The Benefits of Alternatives to Conventional College: Labor-Market Returns to Proprietary Schooling." IZA Discussion Paper No. 10007.

[47] Lang, Kevin and Russell Weinstein. 2012. "Evaluating Student Outcomes at For-Profit Colleges." NBER Working Paper No. 18201.

[48] Lang, Kevin and Russell Weinstein. 2013. "The Wage Effects of Not-for-profit and For-profit Certifications: Better Data, Somewhat Different Results." Labour Economics 24: 230-243.

[49] Liu, Yuen Ting and Clive Belfield. 2014a. "Evaluating For-Profit Higher Education: Evidence from the Education Longitudinal Study." CAPSEE Working Paper, New York, NY.

[50] Liu, Yuen Ting and Clive Belfield. 2014b. "The Labor Market Returns to For-Profit Higher Education: Evidence for Transfer Students. CAPSEE Working Paper, New York, NY.

[51] Long, Bridget Terry. 2014. "The Financial Crisis and College Affordability: How Have Students and Their Families Responded?" In How the Recession Affected Higher Education, Jeffrey Brown and Caroline M. Hoxby (Eds.). University of Chicago Press: Chicago, IL. 
[52] Looney, Adam and Constantine Yannelis. 2015. "A Crisis in Student Loans?: How Changes in the Characteristics of Borrowers and in the Institutions They Attended Contributed to Rising Loan Defaults" Brookings Papers on Economic Activity 2: 1-89.

[53] Scott-Clayton, Judith. 2018. "The Looming Student Loan Default Crisis is Worse than We Thought." Evidence Speaks, Brookings Institution, 2(34), January 10.

[54] Stratford, Michael. 2017. "Trump and DeVos fuel a for-profit college comeback." Politico: https://www.politico.com/story/2017/08/31/devos-trump-forprofit-college-education-242193, last accessed $11 / 6 / 2017$.

[55] Turner, Nicholas. 2011. "Do Students Profit from For-Profit Education? Estimating the Returns to Postsecondary Education with Tax Data." Available at: http://works.bepress.com/nicholas_turner/6/. 
Figure 1: Labor Demand Changes by CBSA, 1997-2000

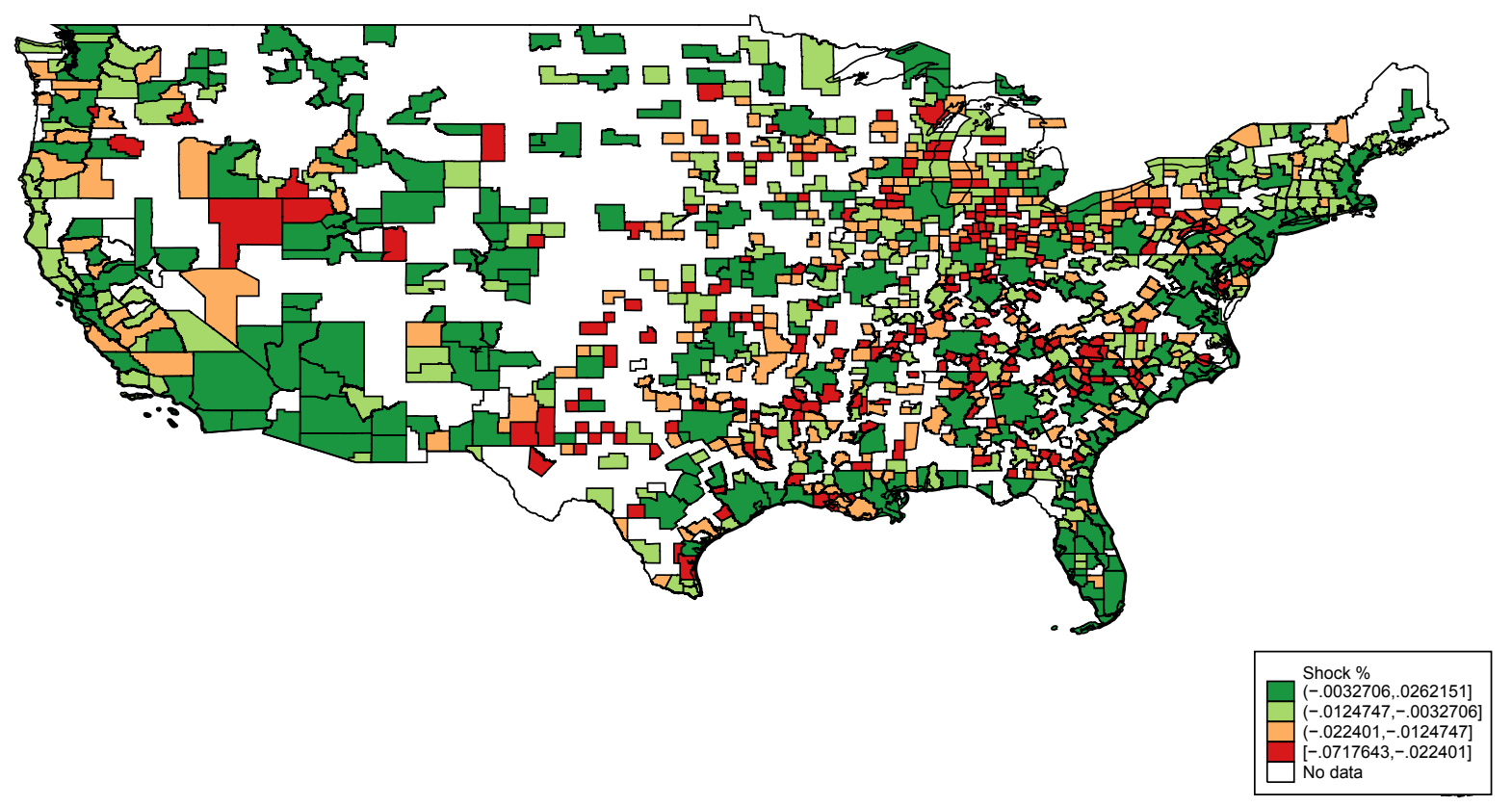

Figure 2: Quartiles of Labor Demand Changes by Year, 2000-2014

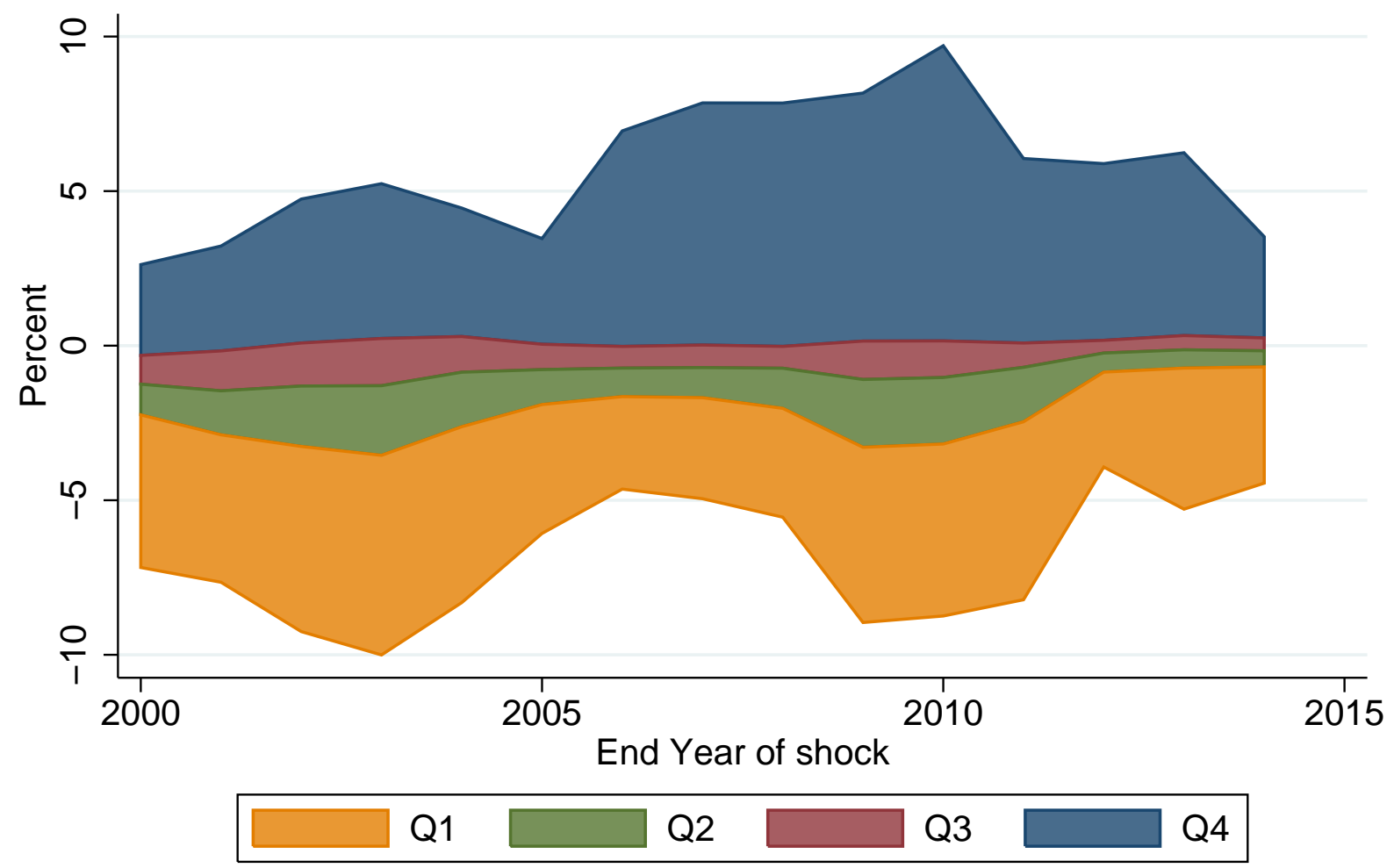


Figure 3: Percent of Two-year and Less-than-two-year For-profit Postsecondary Institutions by CBSA, 2000

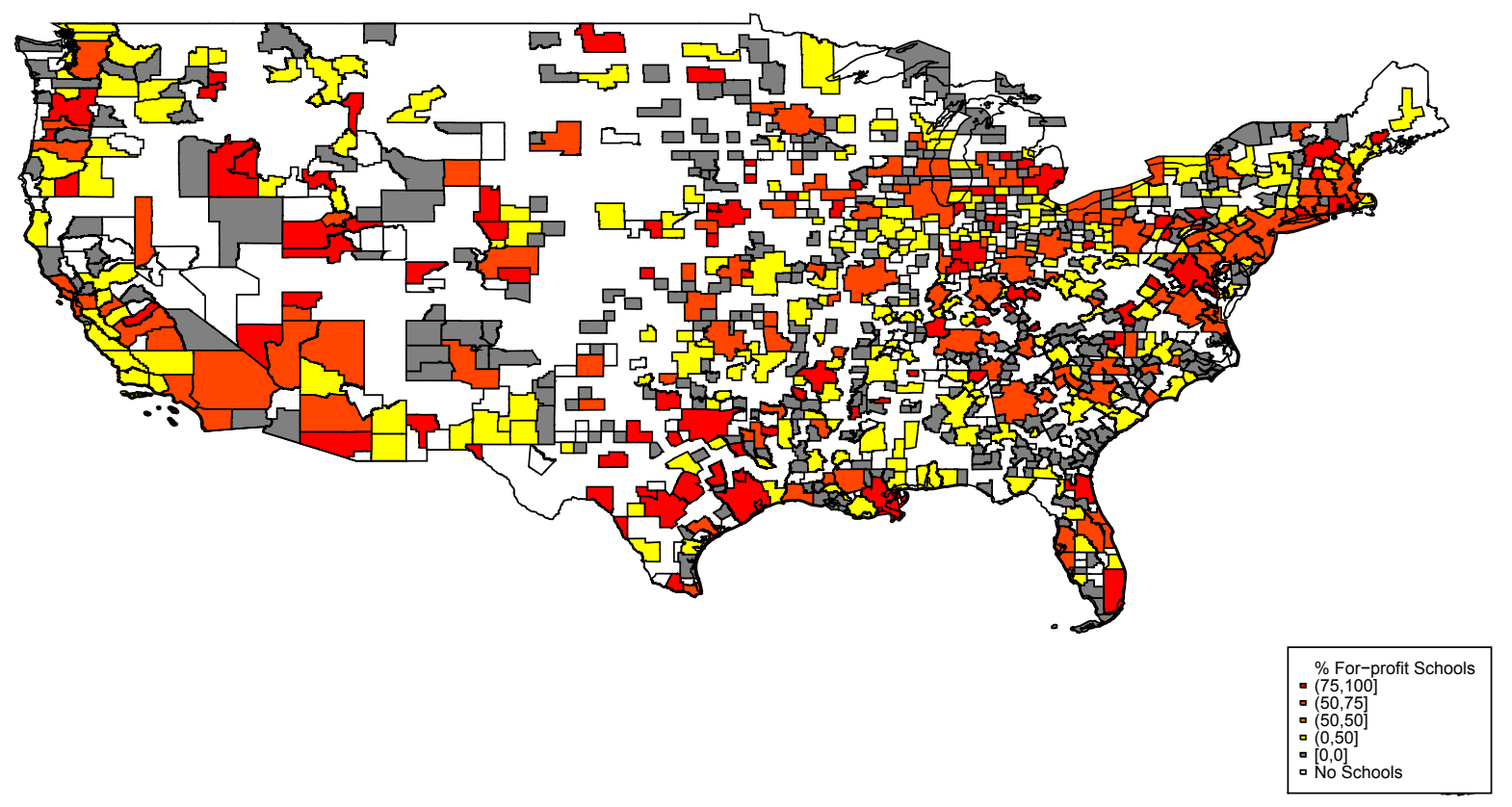

Figure 4: Percent of Four-year For-profit Postsecondary Institutions by CBSA, 2000

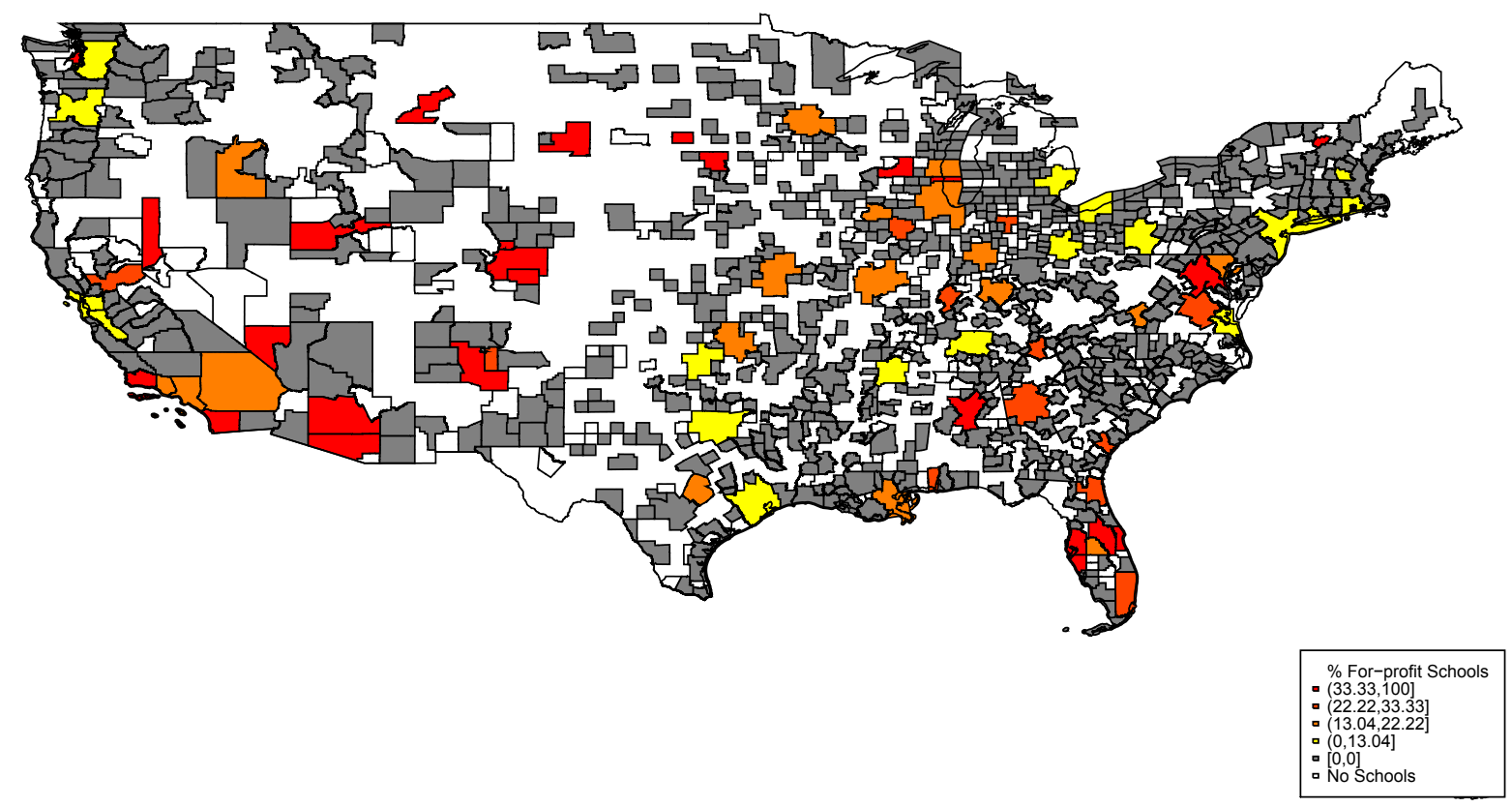


Figure 5: The Correlation of Demeaned Labor Demand Changes and 2000 For-Profit Supply
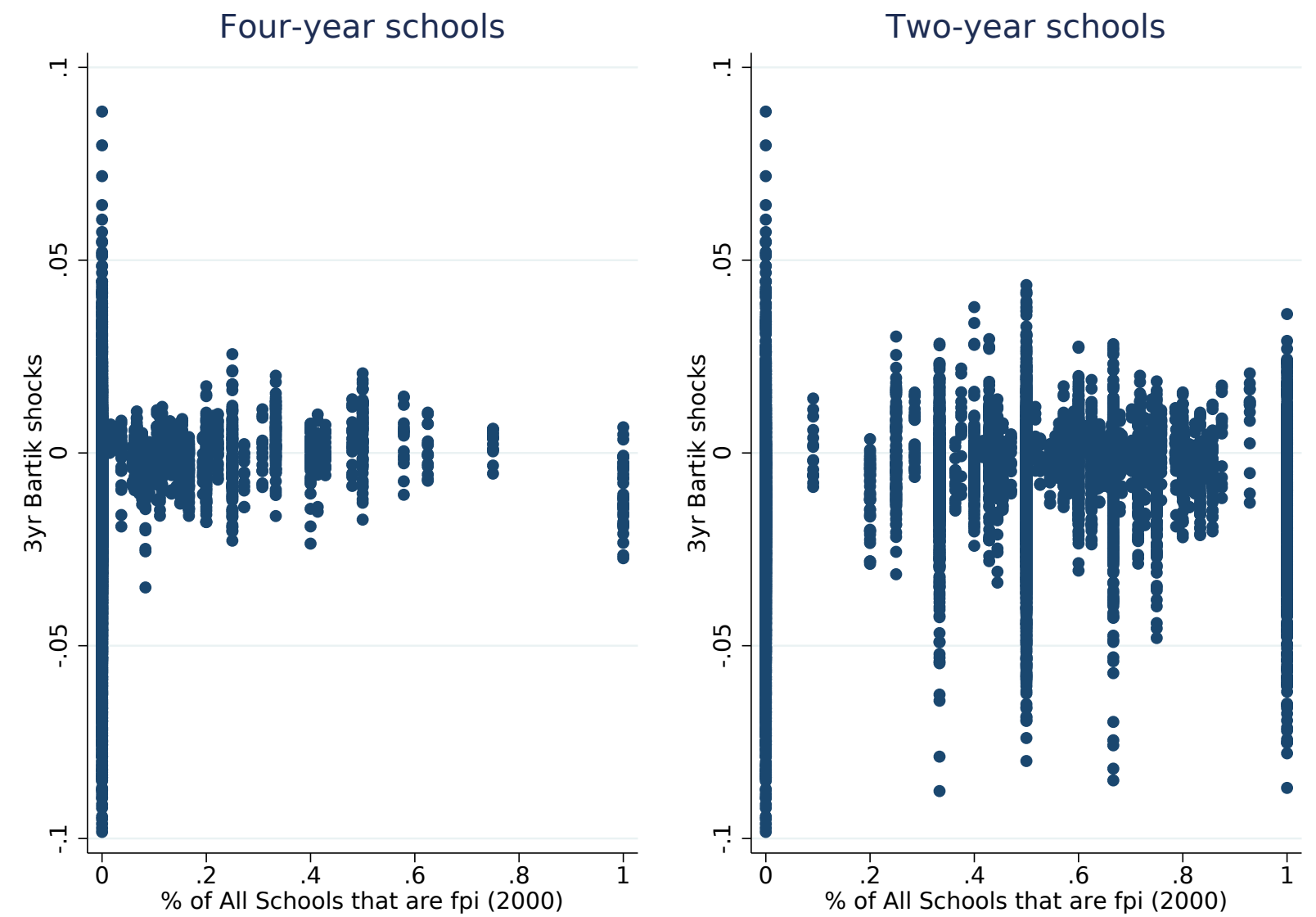

This figure plots the relationship between 3-year rolling predicted labor demand changes at the CBSA-year level that are residual to the CBSA-specific mean with 2000 for-profit supply. Each point shows a separate CBSA-year observation, but only labor demand changes by year. The time span is 2000-14. 
Figure 6: Demeaned Predicted Labor Demand Trends by For-Profit Supply and Institution Type
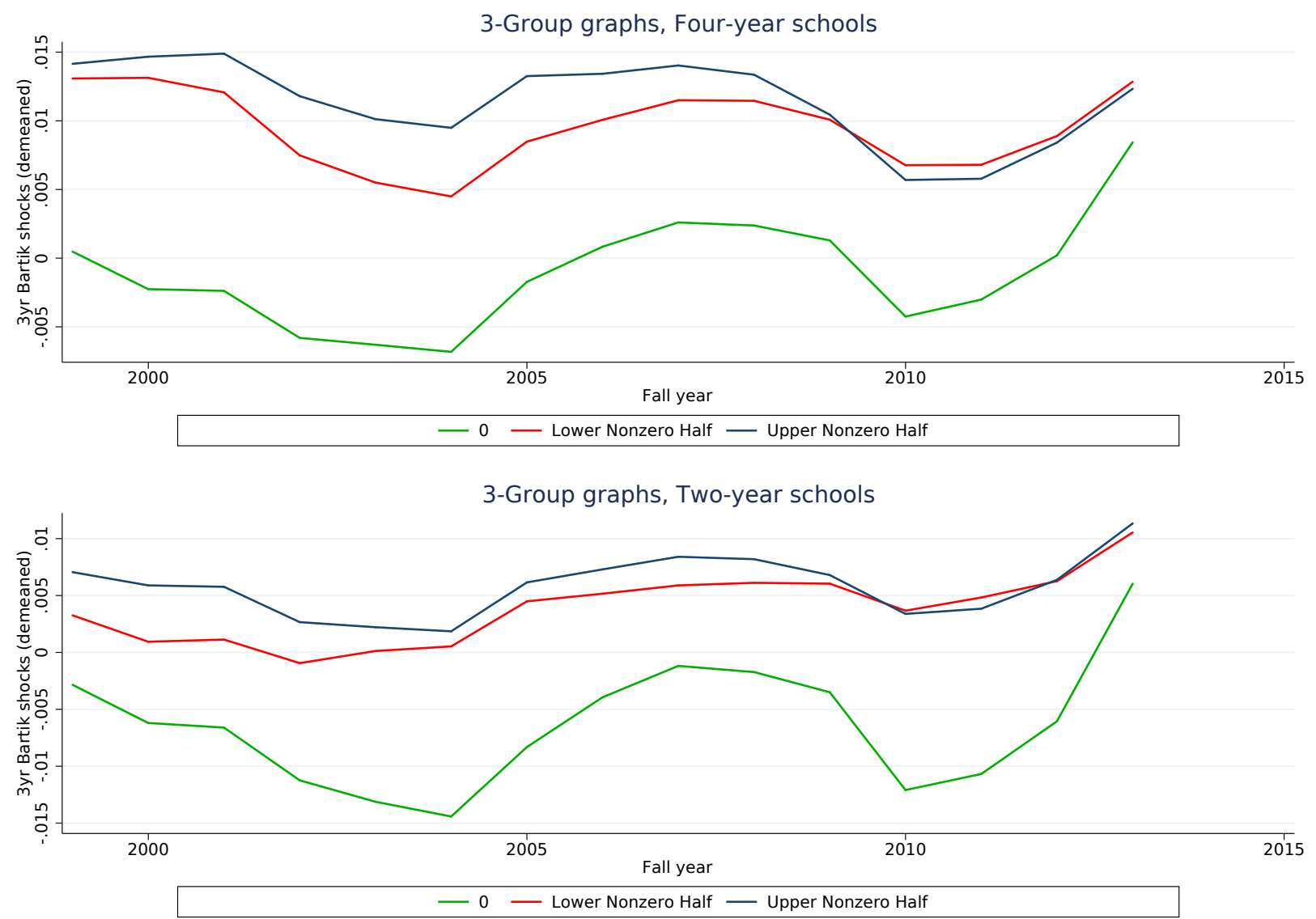

This figure plots trends over time in 3-year rolling predicted labor demand changes that are residual to the CBSA-specific mean for CBSAs that have no for-profits in 2000 and for CBSAs with above and below median for-profit shares among those with any for-profit institutions in 2000. The top panel shows trends among four-year institutions while the bottom panel shows trends among two-year schools. 
Figure 7: Pre-2000 Trends in Educational and Labor Market Outcomes by Labor Demand $x$ For-Profit Supply, Below and Above Median
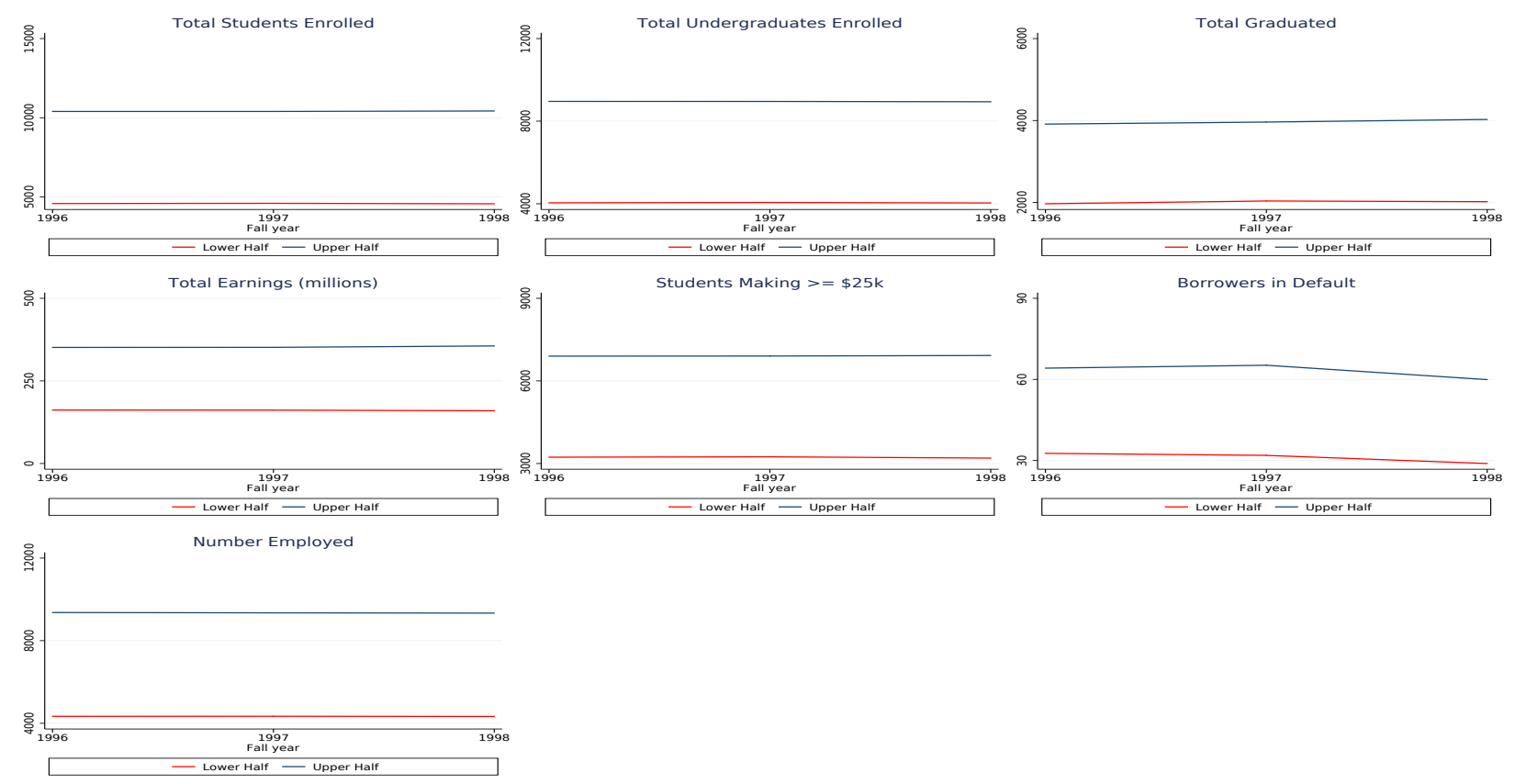

This figure plots pre-2000 trends in educational and labor market outcomes separately for CBSAs that have above and below median levels of labor demand interacted with for-profit supply $(\hat{\eta} *$ Supply). 
Figure 8: First Stage Enrollment Estimates and 95\% Confidence Intervals Using Different Enrollment Measures
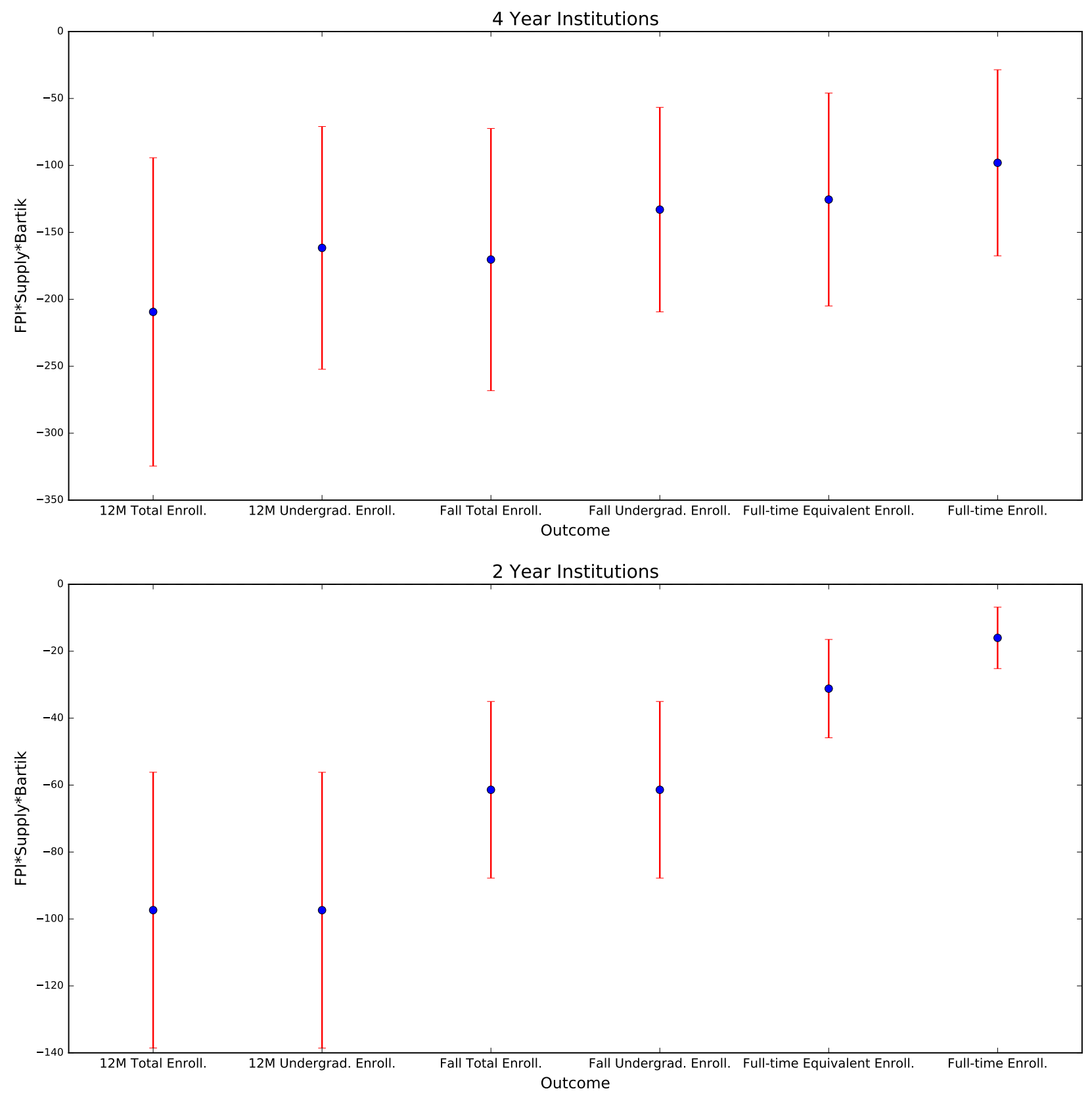

This figure plots the coefficient $\alpha_{6}$ and the $95 \%$ confidence interval from first-stage equation (4), which is the three-way interaction between predicted labor demand $(\hat{\eta})$, baseline for-profit supply, and a for-profit indicator. Each estimate comes from a regression that uses a different enrollment measure. The time span is 2000-14 and the coefficients capture the relative shifts in for-profit enrollment relative to the corresponding public counterpart. The dependent variable is total enrollment aggregated to CBSA, sector (public or for-profit) and level (two-year or four-year). The supply measure is percentage of for-profit institutions at the corresponding level (two year or four-year) in the specific geography at the start of the sample period in fall 2000. All regressions include geography and year fixed effects. Two year institution group includes two-year and less than two year institutions. 


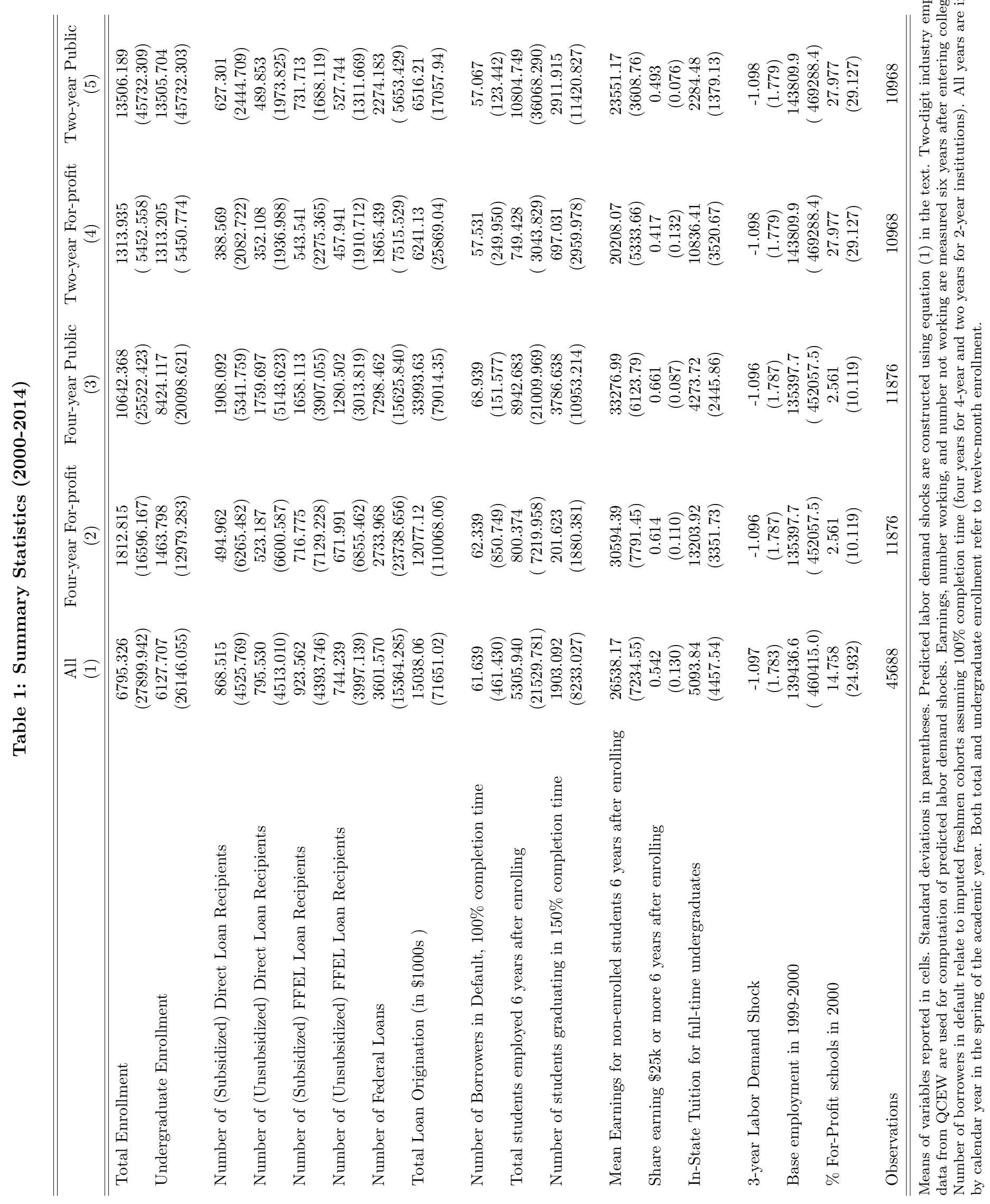




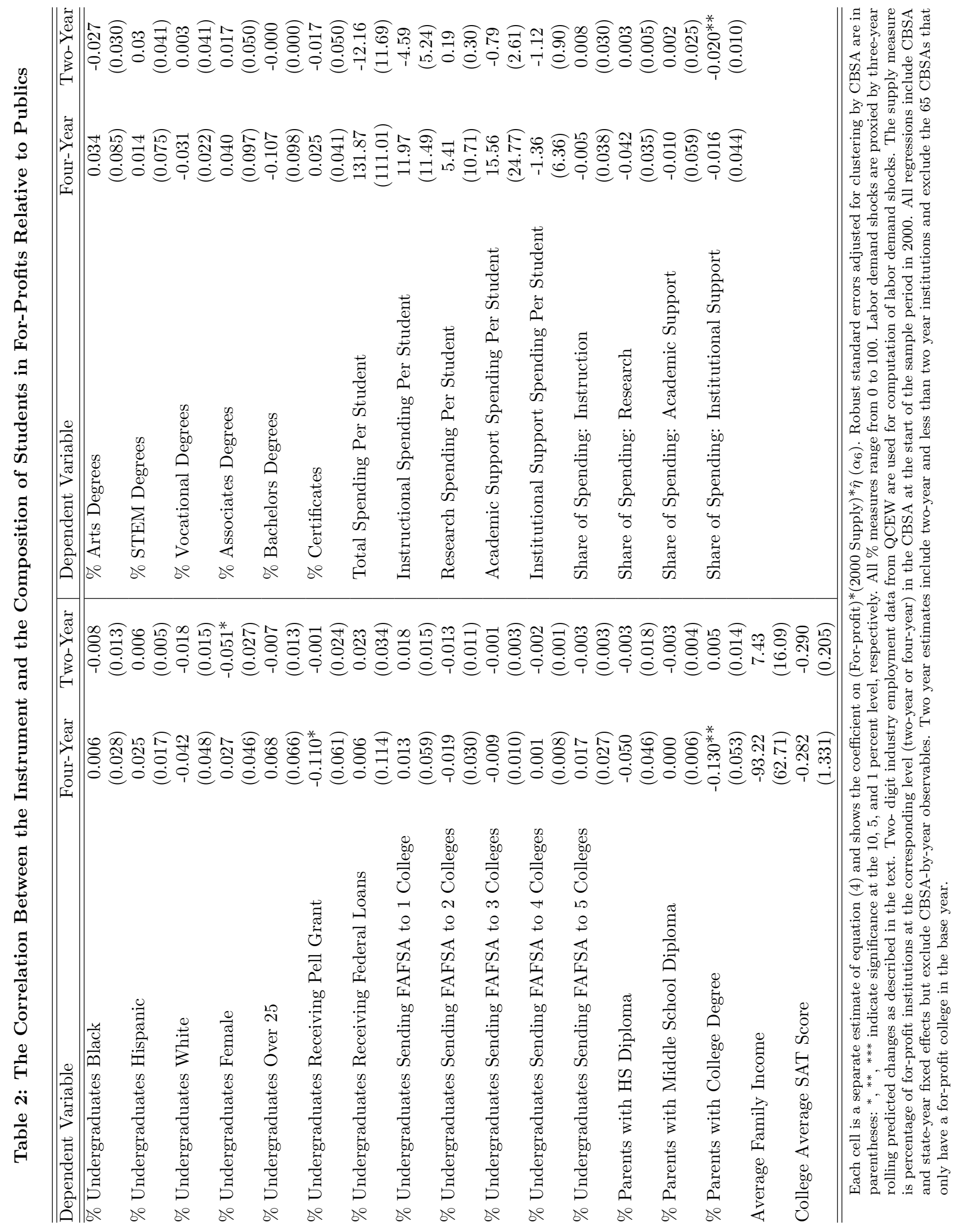


Table 3: First Stage Enrollment Estimates

\begin{tabular}{|c|c|c|c|c|c|c|}
\hline \multirow[t]{2}{*}{ Panel A: 4 year schools } & \multicolumn{2}{|c|}{$2000-2014$} & \multicolumn{2}{|c|}{$2000-2006$} & \multicolumn{2}{|c|}{ 2008-2014 } \\
\hline & (1) & $(2)$ & (3) & (4) & (5) & (6) \\
\hline$\overline{\left(2000 \text { For-profit Supply) }{ }^{*} \hat{\eta}\right.}$ & $\begin{array}{c}12.624 \\
(46.124)\end{array}$ & $\begin{array}{c}25.154 \\
(42.462)\end{array}$ & $\begin{array}{c}39.933 \\
(36.827)\end{array}$ & $\begin{array}{c}46.130 \\
(35.519)\end{array}$ & $\begin{array}{c}88.091^{* * *} \\
(24026)\end{array}$ & $89.163^{* * *}$ \\
\hline (For-profit $^{*}(2000 \text { Supply })^{*} \hat{\eta}$ & $\begin{array}{c}-209.420^{* * *} \\
(58.760) \\
{[-3.564]}\end{array}$ & $\begin{array}{c}-209.420^{* * *} \\
(59.639) \\
{[-3.511]}\end{array}$ & $\begin{array}{c}-148.950^{* * *} \\
(53.599) \\
{[-2.779]}\end{array}$ & $\begin{array}{c}-148.950 * * * \\
(54.328) \\
{[-2.742]}\end{array}$ & $\begin{array}{c}-292.370^{* * *} \\
(68.765) \\
{[-4.252]}\end{array}$ & $\begin{array}{c}-292.370^{* * * *} \\
(69.709) \\
{[-4.194]}\end{array}$ \\
\hline Time Fixed Effects & Year & State*Year & Year & State*Year & Year & State*Year \\
\hline State*FP \& Year*FP & No & No & No & No & No & No \\
\hline$\overline{\text { Observations }}$ & 23482 & 23482 & 11044 & 11044 & 10954 & 10954 \\
\hline R-squared & 0.180 & 0.189 & 0.229 & 0.232 & 0.133 & 0.138 \\
\hline $\mathrm{P}$-value & 0.002 & 0.002 & 0.002 & 0.004 & 0.000 & 0.000 \\
\hline \multirow[t]{2}{*}{ Panel B: 4 year schools } & \multicolumn{2}{|c|}{$2000-2014$} & \multicolumn{2}{|c|}{$2000-2006$} & \multicolumn{2}{|c|}{$2008-2014$} \\
\hline & (1) & $(2)$ & $(3)$ & $(4)$ & $(5)$ & (6) \\
\hline$(2000 \text { For-profit Supply })^{*} \hat{\eta}$ & $\begin{array}{c}22.778 \\
(42.845)\end{array}$ & $\begin{array}{c}35.308 \\
(41.869)\end{array}$ & $\begin{array}{c}53.451 \\
(33.447)\end{array}$ & $\begin{array}{l}59.648^{*} \\
(32.397)\end{array}$ & $\begin{array}{c}92.657^{* * *} \\
(20.359)\end{array}$ & $\begin{array}{c}93.729 * * * \\
(21.510)\end{array}$ \\
\hline (For-profit $)^{*}(2000 \text { Supply })^{*} \hat{\eta}$ & $\begin{array}{c}-229.730^{* * *} \\
(71.427) \\
{[-3.216]}\end{array}$ & $\begin{array}{c}-229.730^{* * *} \\
(72.499) \\
{[-3.169]}\end{array}$ & $\begin{array}{c}-175.990^{* * *} \\
(49.555) \\
{[-3.551]}\end{array}$ & $\begin{array}{c}-175.990^{* * *} \\
(50.233) \\
{[-3.503]}\end{array}$ & $\begin{array}{c}-301.510^{* * *} \\
(60.072) \\
{[-5.019]}\end{array}$ & $\begin{array}{c}-301.510^{\text {*** }} \\
(60.901) \\
{[-4.951]}\end{array}$ \\
\hline Time Fixed Effects & Year & State*Year & Year & State*Year & Year & State*Year \\
\hline State*FP \& Year*FP & Yes & Yes & Yes & Yes & Yes & Yes \\
\hline Observations & 23482 & 23482 & 11044 & 11044 & 10954 & 10954 \\
\hline R-squared & 0.231 & 0.240 & 0.284 & 0.287 & 0.205 & 0.210 \\
\hline $\mathrm{P}$-value & 0.006 & 0.007 & 0.000 & 0.001 & 0.000 & 0.000 \\
\hline \multirow[t]{2}{*}{ Panel C: 2 year schools } & \multicolumn{2}{|c|}{$2000-2014$} & \multicolumn{2}{|c|}{$2000-2006$} & \multicolumn{2}{|c|}{$2008-2014$} \\
\hline & (1) & $(2)$ & (3) & (4) & (5) & (6) \\
\hline$\overline{(2000 \text { For-profit Supply)*} \hat{\eta}}$ & $\begin{array}{c}52.299^{* * *} \\
(11.856)\end{array}$ & $\begin{array}{c}50.074^{* * *} \\
(12.058)\end{array}$ & $\begin{array}{c}64.029^{* * *} \\
(13.751)\end{array}$ & $\begin{array}{c}62.654^{* * *} \\
(14.002)\end{array}$ & $\begin{array}{c}31.870^{* * *} \\
(8.425)\end{array}$ & $\begin{array}{c}31.233^{* * *} \\
(8.591)\end{array}$ \\
\hline 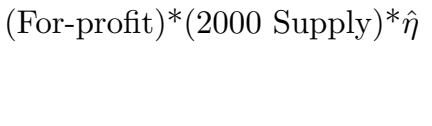 & $\begin{array}{c}-97.355^{* * *} \\
(21.025) \\
{[-4.630]}\end{array}$ & $\begin{array}{c}-97.355^{* * *} \\
(21.366) \\
{[-4.556]}\end{array}$ & $\begin{array}{c}-129.190^{* * *} \\
(25.890) \\
{[-4.990]}\end{array}$ & $\begin{array}{c}-129.190^{* * *} \\
(26.274) \\
{[-4.917]}\end{array}$ & $\begin{array}{c}-65.285^{* * *} \\
(16.359) \\
{[-3.991]}\end{array}$ & $\begin{array}{c}-65.285^{* * *} \\
(16.603) \\
{[-3.932]}\end{array}$ \\
\hline Time Fixed Effects & Year & State*Year & Year & State*Year & Year & State*Year \\
\hline State*FP \& Year*FP & No & No & No & No & No & No \\
\hline Observations & 21666 & 21666 & 10172 & 10172 & 10130 & 10130 \\
\hline are & 0.155 & 0.157 & 0.163 & 0.165 & 0.135 & 0.136 \\
\hline $\mathrm{P}$-value & 0.000 & 0.000 & 0.000 & 0.000 & 0.000 & 0.000 \\
\hline \multirow[t]{2}{*}{ Panel D: 2 year schools } & \multicolumn{2}{|c|}{$2000-2014$} & \multicolumn{2}{|c|}{$2000-2006$} & \multicolumn{2}{|c|}{$2008-2014$} \\
\hline & (1) & $(2)$ & (3) & (4) & (5) & (6) \\
\hline$\overline{(2000}$ For-profit Supply)* $\hat{\eta}$ & $\begin{array}{c}55.879^{* * *} \\
(12.964)\end{array}$ & $\begin{array}{c}53.654^{* * *} \\
(13.152)\end{array}$ & $\begin{array}{c}67.996^{* * *} \\
(14.654)\end{array}$ & $\begin{array}{c}66.621^{* * *} \\
(14.980)\end{array}$ & $\begin{array}{c}28.155^{* * *} \\
(8.698)\end{array}$ & $\begin{array}{c}27.518^{* * *} \\
(8.836)\end{array}$ \\
\hline (For-profit) $)^{*}(2000 \text { Supply })^{*} \hat{\eta}$ & $\begin{array}{c}-104.510^{* * *} \\
(22.740) \\
{[-4.596]}\end{array}$ & $\begin{array}{c}-104.510^{* * *} \\
(23.110) \\
{[-4.522]}\end{array}$ & $\begin{array}{c}-137.120^{* * *} \\
(27.555) \\
{[-4.976]}\end{array}$ & $\begin{array}{c}-137.120^{* * *} \\
(27.965) \\
{[-4.903]}\end{array}$ & $\begin{array}{c}-57.855^{* * *} \\
(16.756) \\
{[-3.453]}\end{array}$ & $\begin{array}{c}-57.855^{* * *} \\
(17.006) \\
{[-3.402]}\end{array}$ \\
\hline Time Fixed Effects & Year & State*Year & Year & State*Year & Year & State*Year \\
\hline State*FP \& Year*FP & Yes & Yes & Yes & Yes & Yes & Yes \\
\hline Observations & 21666 & 21666 & 10172 & 10172 & 10130 & 10130 \\
\hline R-squared & 0.258 & 0.261 & 0.271 & 0.272 & 0.232 & 0.233 \\
\hline $\mathrm{P}$-value & 0.000 & 0.000 & 0.000 & 0.000 & 0.001 & 0.000 \\
\hline
\end{tabular}

Authors estimates of equation (4) in the text using for-profit and public institutions. The dependent variable is total 12-month enrollment aggregated by CBSA, sector (public or for-profit) and level (two-year or four-year). Robust standard errors adjusted for clustering by CBSA are in parentheses: *, ${ }^{* *},{ }^{* *}$ indicate significance at the 10,5 , and 1 percent level, respectively. "P-value" shows the p-value of F-tests for joint significance of instruments. Labor demand shocks are proxied by three-year rolling predicted changes as described in the text. Two- digit industry employment data from QCEW are used for computation of labor demand shocks. The supply measure is percentage of for-profit institutions at the corresponding level (two-year or four-year) in the CBSA in 2000 or 2007 (for 2008-14 period). All regressions include the following CBSA-year level variables as controls: base-year $(t-3)$ employment, gender composition (\% female), racial composition (\% black, \%Hispanic, \%American Indian, \%Asian, \% Two or more races), age composition (\%20-29, \%30-39, \%40 or over), \%poverty and total population. All regressions also include CBSA and year fixed effects, while even columns include state-by-year fixed effects. Two year estimates include two-year and less than two year institutions and exclude the 65 CBSAs that only have a for-profit college in the base year. 
Table 4: Instrumental Variables Estimates of the Effect of For-profit Attendance on the Number and Volume of Student Loan Originations and Defaults

\begin{tabular}{|c|c|c|c|c|c|c|c|c|}
\hline & \multicolumn{8}{|c|}{ Panel A: Number of Loans } \\
\hline & \multicolumn{4}{|c|}{ 4-year Schools } & \multicolumn{4}{|c|}{ 2-year Schools } \\
\hline & $(1)$ & $(2)$ & $(3)$ & $(4)$ & $(5)$ & $(6)$ & $(7)$ & $(8)$ \\
\hline \multirow[t]{2}{*}{ Enroll } & $0.435^{* * *}$ & $0.490 * * *$ & $0.451^{* *}$ & $0.502^{* * *}$ & 0.064 & 0.067 & 0.012 & 0.018 \\
\hline & $(0.162)$ & $(0.114)$ & $(0.192)$ & $(0.147)$ & $(0.128)$ & $(0.123)$ & $(0.233)$ & $(0.220)$ \\
\hline \multirow[t]{2}{*}{ Enroll*For-profit } & $1.087^{* * *}$ & $1.008^{* * *}$ & $1.171^{* * *}$ & $1.108^{* * *}$ & 1.148 & 1.131 & 0.839 & 0.821 \\
\hline & $(0.305)$ & $(0.255)$ & $(0.327)$ & $(0.286)$ & $(0.727)$ & $(0.747)$ & $(1.364)$ & $(1.381)$ \\
\hline Time Fixed Effects & Year & Year & State* Year $^{*}$ & State $^{*}$ Year & Year & Year & State*Year & State*Year \\
\hline State*FP \& Year*FP & No & Yes & No & Yes & No & Yes & No & Yes \\
\hline \multirow[t]{4}{*}{ Observations } & 23482 & 23482 & 23482 & 23482 & 21666 & 21666 & 21666 & 21666 \\
\hline & \multicolumn{8}{|c|}{ Panel B: Loan Origination Amount (\$) } \\
\hline & \multicolumn{4}{|c|}{ 4-year Schools } & \multicolumn{4}{|c|}{ 2-year Schools } \\
\hline & $(1)$ & $(2)$ & $(3)$ & $(4)$ & $(5)$ & $(6)$ & $(7)$ & $(8)$ \\
\hline \multirow[t]{2}{*}{ Enroll } & $1401.50^{* * *}$ & $1823.20^{* * *}$ & $1492.10^{* *}$ & $1893.80^{* * *}$ & 511.30 & 509.73 & 596.42 & 590.47 \\
\hline & $(480.40)$ & $(324.99)$ & $(585.54)$ & $(313.97)$ & $(380.01)$ & $(365.75)$ & $(606.55)$ & $(577.29)$ \\
\hline \multirow[t]{2}{*}{ Enroll*For-profit } & $3375.80^{* * *}$ & $2770.50^{* *}$ & $3846.70^{* * *}$ & $3356.10^{* * *}$ & $5907.50 * * *$ & $5915.30^{* * *}$ & $6412.90^{*}$ & $6427.70^{*}$ \\
\hline & $(1206.60)$ & $(1108.80)$ & $(1220.20)$ & $(1034.70)$ & $(2176.60)$ & $(2252.00)$ & $(3576.30)$ & $(3654.10)$ \\
\hline Time Fixed Effects & Year & Year & State*Year & State*Year & Year & Year & State*Year & State*Year \\
\hline State*FP \& Year*FP & No & Yes & No & Yes & No & Yes & No & Yes \\
\hline \multirow[t]{4}{*}{ Observations } & 23482 & 23482 & 23482 & 23482 & 21666 & 21666 & 21666 & 21666 \\
\hline & \multicolumn{8}{|c|}{ Panel C: Number of Borrowers in Default (100\%) } \\
\hline & \multicolumn{4}{|c|}{ 4-year Schools } & \multicolumn{4}{|c|}{ 2-year Schools } \\
\hline & $(1)$ & $(2)$ & $(3)$ & $(4)$ & $(5)$ & $(6)$ & $(7)$ & $(8)$ \\
\hline \multirow[t]{2}{*}{ Enroll } & $0.064^{*}$ & $0.058^{*}$ & $0.057^{*}$ & $0.051^{*}$ & 0.026 & 0.026 & 0.044 & 0.044 \\
\hline & $(0.036)$ & $(0.030)$ & $(0.034)$ & $(0.027)$ & $(0.016)$ & $(0.016)$ & $(0.067)$ & $(0.066)$ \\
\hline \multirow[t]{2}{*}{ Enroll*For-profit } & $0.108^{* * *}$ & $0.116^{* * *}$ & $0.101^{* * *}$ & $0.106^{* * *}$ & $0.214^{*}$ & $0.214^{*}$ & 0.342 & 0.342 \\
\hline & $(0.038)$ & $(0.040)$ & $(0.038)$ & $(0.040)$ & $(0.117)$ & $(0.119)$ & $(0.482)$ & $(0.483)$ \\
\hline Time Fixed Effects & Year & Year & State*Year & State*Year $^{*}$ & Year & Year & State*Year & State*Year \\
\hline State*FP \& Year*FP & No & Yes & No & Yes & No & Yes & No & Yes \\
\hline Observations & 15347 & 15347 & 15347 & 15347 & 14500 & 14500 & 14500 & 14500 \\
\hline
\end{tabular}

Authors estimates of equation (5) in the text using for-profit and public institutions. The enrollment measure is 12-month total enrollment. Enrollment and outcomes are aggregated by CBSA, institution-type (public or for-profit) and level (two-year or four-year). Robust standard errors adjusted for clustering by CBSA are in parentheses: $*, * *, * * *$ indicate significance at the 10, 5 , and 1 percent level, respectively. All regressions include the following CBSA-year level variables as controls: base-year $(t-3)$ employment, gender composition (\%female), racial composition (\%black, \%Hispanic, \%American India, \%Asian, \% Two or more races), age composition (\%20-29, \%30-39, \%40 or over), \%poverty, and total population. All regressions also include CBSA and year fixed effects. Even columns include state-for profit and year-for profit fixed effects, while columns (3)-(4) and (7)-(8) include state-by-year fixed effects. Two year estimates include two-year and less than two year institutions and exclude the 65 CBSAs that only have a for-profit college in the base year. 
Table 5: Instrumental Variables Estimates of the Effect of For-profit Attendance on Student Borrowing, by Loan Type

\begin{tabular}{|c|c|c|c|c|c|c|c|c|}
\hline & \multicolumn{8}{|c|}{ Panel A: Number Recipients: Direct Subsidized Loans } \\
\hline & \multicolumn{4}{|c|}{ 4-year Schools } & \multicolumn{4}{|c|}{ 2-year Schools } \\
\hline & (1) & $(2)$ & (3) & (4) & (5) & (6) & (7) & (8) \\
\hline \multirow[t]{2}{*}{ Enroll } & $0.343^{* *}$ & $0.329^{* *}$ & $0.353^{* *}$ & $0.336^{* *}$ & 0.008 & 0.009 & -0.035 & -0.032 \\
\hline & $(0.156)$ & $(0.150)$ & $(0.177)$ & $(0.170)$ & $(0.122)$ & $(0.118)$ & $(0.223)$ & $(0.211)$ \\
\hline Enroll*For-profit & $\begin{array}{c}0.614^{* *} \\
(0.293)\end{array}$ & $\begin{array}{c}0.634^{* *} \\
(0.282)\end{array}$ & $\begin{array}{c}0.671^{* *} \\
(0.305)\end{array}$ & $\begin{array}{c}0.692^{* *} \\
(0.303)\end{array}$ & $\begin{array}{c}0.163 \\
(0.721)\end{array}$ & $\begin{array}{c}0.157 \\
(0.742)\end{array}$ & $\begin{array}{c}-0.090 \\
(1.329)\end{array}$ & $\begin{array}{c}-0.099 \\
(1.349)\end{array}$ \\
\hline Time Fixed Effects & Year & Year & State*Year & State*Year & Year & Year & State*Year & State*Year \\
\hline State*FP \& Year*FP & No & Yes & No & Yes & No & Yes & No & Yes \\
\hline \multirow[t]{4}{*}{ Observations } & 23482 & 23482 & 23482 & 23482 & 21666 & 21666 & 21666 & 21666 \\
\hline & \multicolumn{8}{|c|}{ Panel B: Number Recipients: Direct Unsubsidized Loans } \\
\hline & \multicolumn{4}{|c|}{ 4-year Schools } & \multicolumn{4}{|c|}{ 2-year Schools } \\
\hline & (1) & $(2)$ & $(3)$ & (4) & $(5)$ & (6) & (7) & (8) \\
\hline Enroll & $0.296^{* *}$ & $0.293^{* * *}$ & $0.310^{* *}$ & $0.302^{* *}$ & 0.020 & 0.021 & -0.015 & -0.012 \\
\hline & $(0.126)$ & $(0.111)$ & $(0.147)$ & $(0.134)$ & $(0.106)$ & $(0.102)$ & $(0.190)$ & $(0.180)$ \\
\hline \multirow[t]{2}{*}{ Enroll*For-profit } & $0.529 * *$ & $0.534^{* *}$ & $0.600^{* *}$ & $0.610^{* *}$ & 0.245 & 0.240 & 0.033 & 0.025 \\
\hline & $(0.231)$ & $(0.224)$ & $(0.254)$ & $(0.255)$ & $(0.617)$ & $(0.636)$ & $(1.131)$ & $(1.148)$ \\
\hline Time Fixed Effects & Year & Year & State*Year & State*Year & Year & Year & State*Year & State*Year \\
\hline State*FP & No & Yes & No & Yes & No & Yes & No & Yes \\
\hline Observation & 23482 & 23482 & 23482 & 23482 & 21666 & 21666 & 21666 & 21666 \\
\hline & \multicolumn{8}{|c|}{ Panel C: Number Recipients: FFEL Subsidized Loans } \\
\hline & \multicolumn{4}{|c|}{ 4-year Schools } & \multirow{2}{*}{\multicolumn{3}{|c|}{ 2-year Schools }} & \\
\hline & (1) & $(2)$ & $(3)$ & (4) & & & & (8) \\
\hline Enroll & $0.155^{* *}$ & $0.168^{* * *}$ & $0.175^{* *}$ & $0.186^{* * *}$ & -0.027 & -0.026 & -0.093 & -0.090 \\
\hline Enroll*For-profit & $(0.068)$ & $\begin{array}{c}(0.061) \\
044 * * *\end{array}$ & $\begin{array}{c}(0.081) \\
0487 * *\end{array}$ & & $(0.033)$ & $(0.033)$ & $(0.094)$ & $(0.091)$ \\
\hline Enroll*For-profit & $\begin{array}{c}0.457 \\
(0.117)\end{array}$ & $\begin{array}{c}0.442^{* * *} \\
(0.114)\end{array}$ & $\begin{array}{c}0.487^{* * *} \\
(0.134)\end{array}$ & $\begin{array}{c}0.476^{* * *} \\
(0.134)\end{array}$ & $\begin{array}{c}0.007 \\
(0.213)\end{array}$ & $\begin{array}{c}0.000 \\
(0.215)\end{array}$ & $\begin{array}{l}-0.426 \\
(0.625)\end{array}$ & $\begin{array}{l}-0.436 \\
(0.631)\end{array}$ \\
\hline Time Fixed Effects & Year & Year & State $^{*}$ Year & State*Year $^{*}$ & Year & Year & State $^{*}$ Year & State $^{*}$ Year \\
\hline State*FP \& Year*FP & No & Yes & No & Yes & No & Yes & No & Yes \\
\hline \multirow[t]{4}{*}{ Observations } & 17290 & 17290 & 17290 & 17290 & 15946 & 15946 & 15946 & 15946 \\
\hline & \multicolumn{8}{|c|}{ Panel D: Number Recipients: FFEL Unsubsidized Loans } \\
\hline & \multicolumn{4}{|c|}{ 4-year Schools } & \multicolumn{4}{|c|}{ 2-year Schools } \\
\hline & (1) & (2) & (3) & (4) & (5) & (6) & (7) & (8) \\
\hline Enroll & $0.096^{*}$ & $0.110^{* *}$ & $0.112^{*}$ & $0.125 * *$ & -0.004 & $\begin{array}{l}-0.002 \\
(0.024)\end{array}$ & -0.043 & -0.040 \\
\hline Enroll*For-profit & $\begin{array}{c}0.414^{* * *} \\
(0.074)\end{array}$ & $\begin{array}{c}0.397^{* * *} * \\
(0.074)\end{array}$ & $\begin{array}{c}0.438^{* * *} * \\
(0.086)\end{array}$ & $\begin{array}{c}0.424^{* * *} * \\
(0.087)\end{array}$ & $\begin{array}{c}0.162 \\
(0.152)\end{array}$ & $\begin{array}{c}0.154 \\
(0.153)\end{array}$ & $\begin{array}{c}-0.093 \\
(0.366)\end{array}$ & $\begin{array}{c}-0.102 \\
(0.368)\end{array}$ \\
\hline Time Fixed Effects & Year & Year & State*Year & State*Year & Year & Year & State*Year & State*Year \\
\hline State*FP \& Year*FP & No & Yes & No & Yes & $\mathrm{No}$ & Yes & No & Yes \\
\hline vations & 17290 & 17290 & 17290 & 17290 & 15946 & 15946 & 15946 & 15946 \\
\hline
\end{tabular}

Authors estimates of equation (5) in the text using for-profit and public institutions. The enrollment measure is 12-month total enrollment. Enrollment and outcomes are aggregated by CBSA, institution-type (public or for-profit) and level (two-year or four-year). Robust standard errors adjusted for clustering by CBSA are in parentheses: $*, * *, * * *$ indicate significance at the 10,5 , and 1 percent level, respectively. All regressions include the following CBSA-year level variables as controls: base-year $(t-3)$ employment, gender composition (\%female), racial composition (\%black, \%Hispanic, \%American India, \%Asian, \% Two or more races), age composition (\%20-29, \%30-39, \%40 or over), \%poverty, and total population. All regressions also include CBSA and year fixed effects. Even columns include state-for profit and year-for profit fixed effects, while columns (3)-(4) and (7)-(8) include state-by-year fixed effects. Two year estimates include two-year and less than two year institutions and exclude the 65 CBSAs that only have a for-profit college in the base year. 


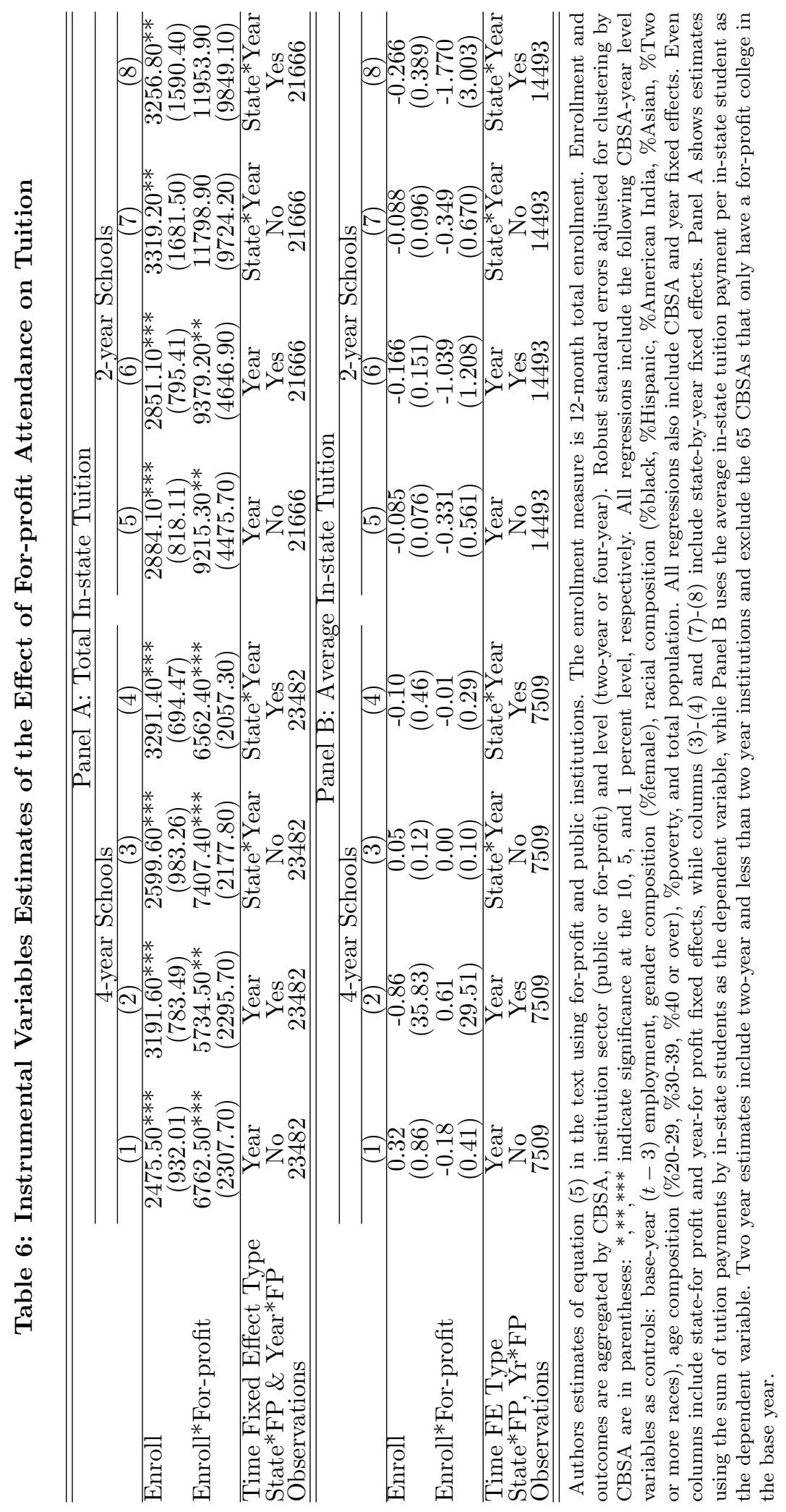


Table 7: Instrumental Variables Estimates of the Effect of For-profit Attendance on Graduation, Employment, and Earnings

\begin{tabular}{|c|c|c|c|c|}
\hline & \multicolumn{4}{|c|}{ Panel A: Total Graduated, assuming 150\% Completion Time } \\
\hline & \multicolumn{2}{|c|}{ 4-year Schools } & \multicolumn{2}{|c|}{ 2-year Schools } \\
\hline & (1) & $(2)$ & $(3)$ & $(4)$ \\
\hline \multirow[t]{2}{*}{ Enroll } & $0.411^{* * *}$ & $0.399^{* * *}$ & 0.173 & $0.179^{*}$ \\
\hline & $(0.103)$ & $(0.093)$ & $(0.114)$ & $(0.108)$ \\
\hline \multirow[t]{2}{*}{ Enroll*For-profit } & -0.135 & -0.122 & 0.298 & 0.281 \\
\hline & $(0.257)$ & $(0.266)$ & $(0.768)$ & $(0.780)$ \\
\hline Time Fixed Effects & State $^{*}$ Year & State $^{*}$ Year & State $^{*}$ Year & State $^{*}$ Year \\
\hline State*FP \& Year*FP & No & Yes & No & Yes \\
\hline \multirow[t]{4}{*}{ Observations } & 18854 & 18854 & 17392 & 17392 \\
\hline & \multicolumn{4}{|c|}{ Panel B: Number Employed, 6 years after enrollment } \\
\hline & \multicolumn{2}{|c|}{ 4-year Schools } & \multicolumn{2}{|c|}{ 2-year Schools } \\
\hline & (1) & $(2)$ & $(3)$ & $(4)$ \\
\hline \multirow[t]{2}{*}{ Enroll } & $0.859^{* * *}$ & $0.875^{* * *}$ & $0.800^{* * *}$ & $0.800^{* * *}$ \\
\hline & $(0.029)$ & $(0.022)$ & $(0.099)$ & $(0.099)$ \\
\hline \multirow[t]{2}{*}{ Enroll*For-profit } & $-0.093^{* *}$ & $-0.110^{* *}$ & -0.358 & -0.356 \\
\hline & $(0.044)$ & $(0.048)$ & $(0.780)$ & $(0.785)$ \\
\hline Time Fixed Effects & State*Year & State*Year & State*Year & State*Year $^{*}$ \\
\hline State*FP \& Year*FP & No & Yes & No & Yes \\
\hline \multirow[t]{4}{*}{ Observations } & 9452 & 9452 & 8710 & 8710 \\
\hline & \multicolumn{4}{|c|}{ Panel C: Total Earnings, 6 years after enrollment } \\
\hline & \multicolumn{2}{|c|}{ 4-year Schools } & \multicolumn{2}{|c|}{ 2-year Schools } \\
\hline & $(1)$ & $(2)$ & $(3)$ & $(4)$ \\
\hline \multirow[t]{2}{*}{ Enroll } & $35981.20^{* * *}$ & $36887.60^{* * *}$ & $25879.60^{* * *}$ & $25865.20^{* * *}$ \\
\hline & $(3396.50)$ & $(2830.50)$ & $(6618.60)$ & $(6674.90)$ \\
\hline \multirow[t]{2}{*}{ Enroll*For-profit } & -5138.10 & -6107.60 & -9718.70 & -8541.20 \\
\hline & $(6306.90)$ & $(6624.40)$ & $(52342.50)$ & $(53038.90)$ \\
\hline Time Fixed Effects & State*Year & State*Year & State*Year & State*Year \\
\hline State*FP \& Year*FP & No & Yes & No & Yes \\
\hline \multirow[t]{4}{*}{ Observations } & 9452 & 9452 & 8710 & 8710 \\
\hline & \multicolumn{4}{|c|}{ "Panel D: Total Students Making $\$ 25 \mathrm{k}, 6$ years after enrollment } \\
\hline & \multicolumn{2}{|c|}{ 4-year Schools } & \multicolumn{2}{|c|}{ 2-year Schools } \\
\hline & $(1)$ & $(2)$ & $(3)$ & $(4)$ \\
\hline \multirow[t]{2}{*}{ Enroll } & $0.702^{* * *}$ & $0.713^{* * *}$ & $0.623^{* * *}$ & $0.623^{* * *}$ \\
\hline & $(0.051)$ & $(0.043)$ & $(0.207)$ & $(0.210)$ \\
\hline \multirow[t]{2}{*}{ Enroll*For-profit } & -0.073 & -0.085 & 0.379 & 0.419 \\
\hline & $(0.100)$ & $(0.108)$ & $(1.607)$ & $(1.632)$ \\
\hline Time Fixed Effects & State*Year & State*Year & State*Year & State*Year $^{*}$ \\
\hline State*FP \& Year*FP & No & Yes & No & Yes \\
\hline Observations & 9452 & 9452 & 8710 & 8710 \\
\hline
\end{tabular}

Authors estimates of equation (5) in the text using for-profit and public institutions. The enrollment measure is 12 -month total enrollment. Enrollment and outcomes are aggregated by CBSA, institution-type (public or for-profit) and level (two-year or four-year). Robust standard errors adjusted for clustering by CBSA are in parentheses: *,**,*** indicate significance at the 10, 5 , and 1 percent level, respectively. All regressions include the following CBSA-year level variables as controls: base-year $(t-3)$ employment, gender composition (\%female), racial composition (\%black, \%Hispanic, \%American India, \%Asian, \% Two or more races), age composition (\%20-29, \%30-39, \%40 or over), \%poverty, and total population. All regressions also include CBSA and state-by-year fixed effects. Even columns include state-for profit and year-for profit fixed effects. Two year estimates include two-year and less than two year institutions and exclude the 65 CBSAs that only have a for-profit college in the base year. 
Table 8: Instrumental Variables Estimates Including Current-year and One-year Leads of Predicted Labor Demand Changes

\begin{tabular}{|c|c|c|c|c|c|c|c|c|}
\hline & \multicolumn{8}{|c|}{ Panel A: Number of Loans } \\
\hline & \multicolumn{4}{|c|}{ 4-year Schools } & \multicolumn{4}{|c|}{ 2-year Schools } \\
\hline & (1) & $(2)$ & $(3)$ & (4) & $(5)$ & (6) & (7) & (8) \\
\hline \multirow[t]{2}{*}{ Enroll } & $0.453^{* *}$ & $0.508^{* * *}$ & $0.466^{*}$ & $0.519^{* * *}$ & 0.002 & 0.009 & -0.062 & -0.050 \\
\hline & $(0.205)$ & $(0.142)$ & $(0.241)$ & $(0.181)$ & $(0.129)$ & $(0.123)$ & $(0.219)$ & $(0.205)$ \\
\hline \multirow[t]{2}{*}{ Enroll*For-profit } & $1.222^{* * *}$ & $1.142^{* * *}$ & $1.308^{* * *}$ & $1.246^{* * *}$ & 0.899 & 0.870 & 0.504 & 0.481 \\
\hline & $(0.340)$ & $(0.270)$ & $(0.357)$ & $(0.304)$ & $(0.771)$ & $(0.781)$ & $(1.338)$ & $(1.336)$ \\
\hline Time Fixed Effects & Year & Year & State*Year & State*Year & Year & Year & State*Year & State*Year \\
\hline State*FP \& Year*FP & No & Yes & No & Yes & No & Yes & No & Yes \\
\hline \multirow[t]{4}{*}{ Observations } & 20290 & 20290 & 20290 & 20290 & 18736 & 18736 & 18736 & 18736 \\
\hline & \multicolumn{8}{|c|}{ 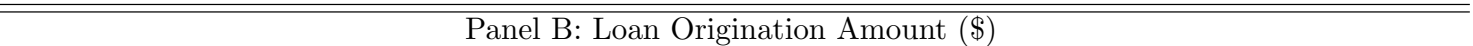 } \\
\hline & \multicolumn{4}{|c|}{ 4-year Schools } & \multicolumn{4}{|c|}{ 2-year Schools } \\
\hline & (1) & $(2)$ & $(3)$ & (4) & $(5)$ & $(6)$ & (7) & $(8)$ \\
\hline \multirow{2}{*}{ Enroll } & $1451.10^{* *}$ & $1860.80^{* * *}$ & $1535.20^{* *}$ & $1927.20^{* * *}$ & 291.11 & 302.92 & 288.24 & 302.90 \\
\hline & $(598.04)$ & $(325.77)$ & $(754.87)$ & $(406.59)$ & $(357.96)$ & $(344.31)$ & $(515.31)$ & $(491.21)$ \\
\hline \multirow[t]{2}{*}{ Enroll*For-profit } & $3804.30^{* * *}$ & $3217.40^{* * *}$ & $4338.30^{* * *}$ & $3880.60^{* * *}$ & $5016.90^{* *}$ & $4972.20^{* *}$ & 4999.10 & 4972.00 \\
\hline & $(1156.30)$ & $(1032.30)$ & $(1194.90)$ & $(984.49)$ & $(2121.40)$ & $(2160.70)$ & $(3115.90)$ & $(3142.60)$ \\
\hline Time Fix & Year & Year & State*Year & State*Year & Year & Year & State*Year & State*Year \\
\hline State*FP \& Y & No & Yes & No & Yes & No & Yes & No & Yes \\
\hline \multirow[t]{4}{*}{ Observations } & 20290 & 20290 & 20290 & 20290 & 18736 & 18736 & 18736 & 18736 \\
\hline & \multicolumn{8}{|c|}{ 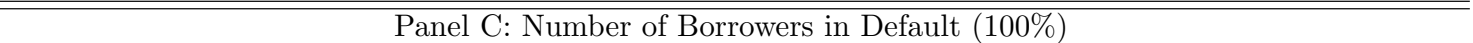 } \\
\hline & \multicolumn{4}{|c|}{ 4-year Schools } & \multicolumn{4}{|c|}{ 2-year Schools } \\
\hline & (1) & $(2)$ & $(3)$ & (4) & (5) & $(6)$ & (7) & (8) \\
\hline \multirow[t]{2}{*}{ Enroll } & $0.064^{*}$ & $0.058^{*}$ & $0.057^{*}$ & $0.051^{*}$ & 0.026 & 0.026 & 0.044 & 0.044 \\
\hline & $(0.036)$ & $(0.030)$ & $(0.034)$ & $(0.027)$ & $(0.016)$ & $(0.016)$ & $(0.068)$ & $(0.067)$ \\
\hline \multirow[t]{2}{*}{ Enroll*For-profit } & $0.108^{* * *}$ & $0.117^{* * *}$ & $0.101^{* * *}$ & $0.107^{* * *}$ & $0.213^{*}$ & $0.213^{*}$ & 0.344 & 0.345 \\
\hline & $(0.038)$ & $(0.041)$ & $(0.039)$ & $(0.041)$ & $(0.116)$ & $(0.117)$ & $(0.487)$ & $(0.488)$ \\
\hline Time Fixed Effects & Year & Year & State*Year & State*Year & Year & Year & State*Year & State*Year \\
\hline State*FP \& Year*FP & No & Yes & No & Yes & No & Yes & No & Yes \\
\hline \multirow[t]{4}{*}{ Observations } & 15283 & 15283 & 15283 & 15283 & 14462 & 14462 & 14462 & 14462 \\
\hline & \multicolumn{8}{|c|}{ Panel D: Number Employed, 6 years after enrollment } \\
\hline & \multicolumn{4}{|c|}{ 4-year Schools } & \multicolumn{4}{|c|}{ 2-year Schools } \\
\hline & (1) & $(2)$ & $(3)$ & (4) & (5) & $(6)$ & (7) & (8) \\
\hline Enroll & $\begin{array}{c}0.857^{* * *} \\
(0.027)\end{array}$ & $\begin{array}{c}0.874^{* * *} \\
(0.019)\end{array}$ & $\begin{array}{c}0.856^{* * *} \\
(0.029)\end{array}$ & $\begin{array}{c}0.875^{* * *} \\
(0.021)\end{array}$ & $\begin{array}{c}0.592 \\
(1.213)\end{array}$ & $\begin{array}{c}0.590 \\
(1.238)\end{array}$ & $\begin{array}{c}0.791^{* * *} \\
(0.099)\end{array}$ & $\begin{array}{c}0.791^{* * *} \\
(0.099)\end{array}$ \\
\hline Enroll*For-profit & $\begin{array}{c}-0.092^{* *} \\
(0.043)\end{array}$ & $\begin{array}{c}-0.112^{* *} \\
(0.048)\end{array}$ & $\begin{array}{c}-0.092^{* *} \\
(0.045)\end{array}$ & $\begin{array}{c}-0.111^{* *} \\
(0.049)\end{array}$ & $\begin{array}{c}-1.966 \\
(9.308)\end{array}$ & $\begin{array}{l}-1.994 \\
(9.552)\end{array}$ & $\begin{array}{l}-0.427 \\
(0.782)\end{array}$ & $\begin{array}{l}-0.425 \\
(0.787)\end{array}$ \\
\hline Time Fixed Effects & Year & Year & State*Year & State*Year & Year & Year & State*Year & State*Year \\
\hline State*FP \& Year*FP & No & Yes & No & Yes & No & Yes & No & Yes \\
\hline Observations & 9410 & 9410 & 9410 & 9410 & 8684 & 8684 & 8684 & 8684 \\
\hline
\end{tabular}

Authors estimates of equation (5) in the text using for-profit and public institutions. We include controls for the current-year (year $\hat{\eta}_{t}$ ) and one-year lead $\left(\hat{\eta}_{t+1}\right)$ predicted labor demand changes. The enrollment measure is 12-month total enrollment. Enrollment and outcomes are aggregated by CBSA, institution-type (public or for-profit) and level (two-year or four-year). Robust standard errors adjusted for clustering by CBSA are in parentheses: *,**,*** indicate significance at the 10, 5 , and 1 percent level, respectively. All regressions include the following CBSA-year level variables as controls: base-year $(t-3)$ employment, gender composition (\%female), racial composition (\%black, \%Hispanic, \%American India, \%Asian, \% Two or more races), age composition (\%20-29, \%30-39, \%40 or over), \%poverty, and total population. All regressions also include CBSA and year fixed effects. Even columns include state-for profit and year-for profit fixed effects, while columns (3)-(4) and (7)-(8) include state-by-year fixed effects. Two year estimates include two-year and less than two year institutions and exclude the 65 CBSAs that only have a for-profit college in the base year. 
Table 9: Instrumental Variables Estimates of the Effect of For-profit Attendance, 4-year Schools by Different Categorizations

\begin{tabular}{|c|c|c|c|c|c|c|c|c|}
\hline & \multicolumn{8}{|c|}{ Panel A: Number of Loans } \\
\hline & \multicolumn{4}{|c|}{$>25 \%$ Bachelors Degrees } & \multicolumn{4}{|c|}{$>25$ th Percentile Bachelors Degrees } \\
\hline & (1) & $(2)$ & $(3)$ & (4) & $(5)$ & $(6)$ & (7) & (8) \\
\hline \multirow[t]{2}{*}{ Enroll } & $0.372^{* * *}$ & $0.429^{* * *}$ & $0.390^{* * *}$ & $0.450^{* * *}$ & $0.392^{* * *}$ & $0.391^{* * *}$ & $0.393^{* * *}$ & $0.392^{* * *}$ \\
\hline & $(0.124)$ & $(0.098)$ & $(0.141)$ & $(0.108)$ & $(0.104)$ & $(0.097)$ & $(0.108)$ & $(0.102)$ \\
\hline \multirow[t]{2}{*}{ Enroll*For-profit } & $0.898^{* * *}$ & $0.847^{* * *}$ & $0.999^{* * *}$ & $0.943^{* * *}$ & $0.871^{* * *}$ & $0.872^{* * *}$ & $0.885^{* * *}$ & $0.887^{* * *}$ \\
\hline & $(0.288)$ & $(0.268)$ & $(0.259)$ & $(0.229)$ & $(0.173)$ & $(0.162)$ & $(0.175)$ & $(0.164)$ \\
\hline Time Fixed Effect Type & Year & Year & State*Year & State*Year & Year & Year & State*Year & State*Year \\
\hline State*FP \& Year*FP & No & Yes & No & Yes & No & Yes & No & Yes \\
\hline \multirow[t]{4}{*}{ Observations } & 23288 & 23288 & 23288 & 23288 & 21492 & 21492 & 21492 & 21492 \\
\hline & \multicolumn{8}{|c|}{ Panel B: Loan Origination Amount (\$) } \\
\hline & \multicolumn{4}{|c|}{$>25 \%$ Bachelors Degrees } & \multicolumn{4}{|c|}{$>25$ th Percentile Bachelors Degrees } \\
\hline & (1) & $(2)$ & $(3)$ & $(4)$ & $(5)$ & $(6)$ & (7) & $(8)$ \\
\hline \multirow[t]{2}{*}{ Enroll } & $931.09^{*}$ & $1120.30^{* *}$ & $1113.40^{* * *}$ & $1333.20^{* * *}$ & $1341.80^{* * *}$ & $1310.60^{* * *}$ & $1345.90^{* * *}$ & $1313.90^{* * *}$ \\
\hline & $(481.22)$ & $(549.39)$ & $(397.25)$ & $(345.16)$ & $(491.30)$ & $(401.96)$ & $(508.31)$ & $(419.29)$ \\
\hline \multirow[t]{2}{*}{ Enroll*For-profit } & 1404.80 & 1234.50 & $2434.80^{* *}$ & $2226.80^{* *}$ & $3171.70^{* * *}$ & $3203.40^{* * *}$ & $3230.80^{* * *}$ & $3262.90^{* * *}$ \\
\hline & $(2112.60)$ & $(2006.80)$ & $(1207.40)$ & $(1099.40)$ & $(1020.60)$ & $(937.01)$ & $(985.02)$ & $(892.79)$ \\
\hline Time Fixed Effect Type & Year & Year & State*Year & State*Year & Year & Year & State*Year & State*Year \\
\hline State*FP \& Year*FP & No & Yes & No & Yes & No & Yes & No & Yes \\
\hline \multirow[t]{4}{*}{ Observations } & 23288 & 23288 & 23288 & 23288 & 21492 & 21492 & 21492 & 21492 \\
\hline & \multicolumn{8}{|c|}{ Panel C: Number of Borrowers in Default (100\%) } \\
\hline & \multicolumn{4}{|c|}{$>25 \%$ Bachelors Degrees } & \multicolumn{4}{|c|}{$>25$ th Percentile Bachelors Degrees } \\
\hline & (1) & $(2)$ & (3) & (4) & (5) & (6) & (7) & (8) \\
\hline \multirow[t]{2}{*}{ Enroll } & 0.047 & 0.047 & 0.042 & 0.041 & $0.012^{* * *}$ & $0.013^{* * *}$ & $0.012^{* * *}$ & $0.012^{* * *}$ \\
\hline & $(0.041)$ & $(0.038)$ & $(0.033)$ & $(0.030)$ & $(0.004)$ & $(0.004)$ & $(0.004)$ & $(0.004)$ \\
\hline \multirow{2}{*}{ Enroll*For-profit } & $0.107^{* *}$ & $0.104^{* *}$ & $0.099^{* *}$ & $0.095^{* *}$ & $0.069^{* * *}$ & $0.068^{* * *}$ & $0.069^{* * *}$ & $0.068^{* * *}$ \\
\hline & $(0.054)$ & $(0.051)$ & $(0.042)$ & $(0.040)$ & $(0.011)$ & $(0.011)$ & $(0.011)$ & $(0.010)$ \\
\hline Time Fixed Effect Type & Year & Year & State*Year & State*Year & Year & Year & State*Year & State*Year \\
\hline State*FP \& Year*FP & No & Yes & No & Yes & No & Yes & No & Yes \\
\hline \multirow[t]{4}{*}{ Observations } & 14922 & 14922 & 14922 & 14922 & 13729 & 13729 & 13729 & 13729 \\
\hline & \multicolumn{8}{|c|}{ Panel D: Number Employed, 6 years after enrollment } \\
\hline & \multicolumn{4}{|c|}{$>25 \%$ Bachelors Degrees } & \multicolumn{4}{|c|}{$>25$ th Percentile Bachelors Degrees } \\
\hline & (1) & $(2)$ & $(3)$ & (4) & $(5)$ & $(6)$ & $(7)$ & $(8)$ \\
\hline Enroll & $0.851^{* * *}$ & $0.856^{* * *}$ & $0.852^{* * *}$ & $0.857^{* * *}$ & $0.826^{* * *}$ & $0.825^{* * *}$ & $0.828^{* * *}$ & $0.827^{* * *}$ \\
\hline & $(0.028)$ & $(0.025)$ & $(0.027)$ & $(0.024)$ & $(0.032)$ & $(0.025)$ & $(0.034)$ & $(0.027)$ \\
\hline Enroll*For-profit & $\begin{array}{c}-0.130^{* * *} \\
(0.044)\end{array}$ & $\begin{array}{c}-0.137^{* * * *} \\
(0.042)\end{array}$ & $\begin{array}{c}-0.128^{* * *} \\
(0.043)\end{array}$ & $\begin{array}{c}-0.134^{* * *} \\
(0.041)\end{array}$ & $\begin{array}{c}-0.144^{* *} \\
(0.066)\end{array}$ & $\begin{array}{c}-0.142^{* *} \\
(0.056)\end{array}$ & $\begin{array}{c}-0.140^{* *} \\
(0.062)\end{array}$ & $-0.138^{* * *}$ \\
\hline Time Fixed Effect Type & Year & Year & State*Year & State*Year & Year & Year & State*Year & State*Year \\
\hline State*FP \& Year*FP & No & Yes & No & Yes & No & Yes & No & Yes \\
\hline Observations & 9386 & 9386 & 9386 & 9386 & 8710 & 8710 & 8710 & 8710 \\
\hline
\end{tabular}

Authors estimates of equation (5) in the text using for-profit and public institutions. The enrollment measure is 12-month total enrollment. Enrollment and outcomes are aggregated by CBSA and institution-type (public or for-profit). Only four-year institutions are used in these estimates. In Columns (1)-(4), four-year institutions are those for which over $25 \%$ of all degrees awarded are Bachelors degrees. In Columns (5)-(8), four-year institutions are the top $75 \%$ of institutions in the distribution of the percent of degrees constituted by Bachelors degrees (among institutions that award any BA). Robust standard errors adjusted for clustering by CBSA are in parentheses: $*, * *, * * *$ indicate significance at the 10,5 , and 1 percent level, respectively. All regressions include the following CBSA-year level variables as controls: base-year $(t-3)$ employment, gender composition (\%female), racial composition (\%black, \%Hispanic, \%American India, \%Asian, \%Two or more races), age composition (\%20-29, \%30-39, \%40 or over), \%poverty, and total population. All regressions also include CBSA and year fixed effects. Even columns include state-for profit and year-for profit fixed effects, while columns (3)-(4) and (7)-(8) include state-by-year fixed effects. Two year estimates include two-year and less than two year institutions and exclude the 65 CBSAs that only have a for-profit college in the base year. 


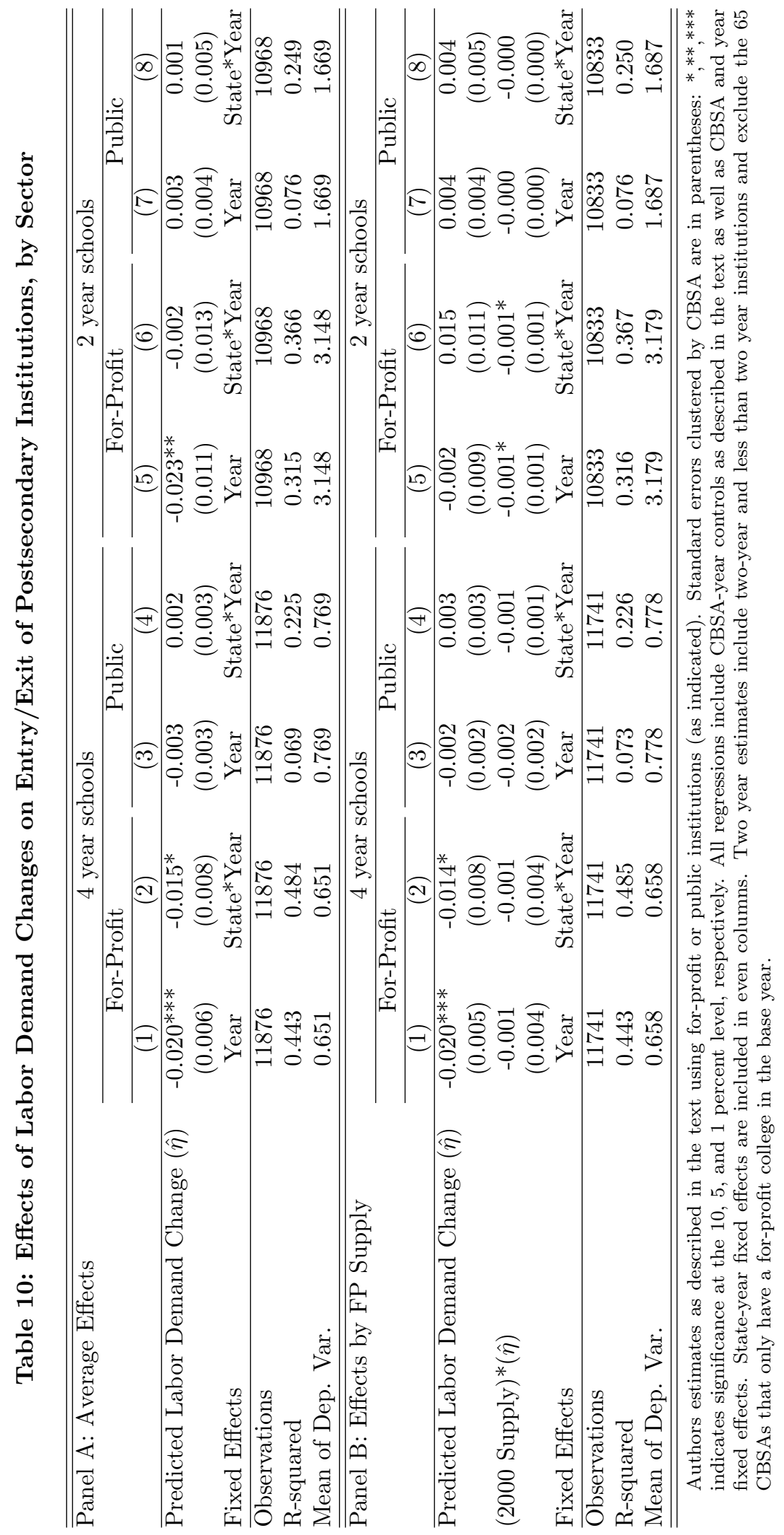




\section{Online Appendix}

\section{Online Appendix: Not for Publication}

Figure A-1: Demeaned Predicted Labor Demand Trends by For-Profit Supply
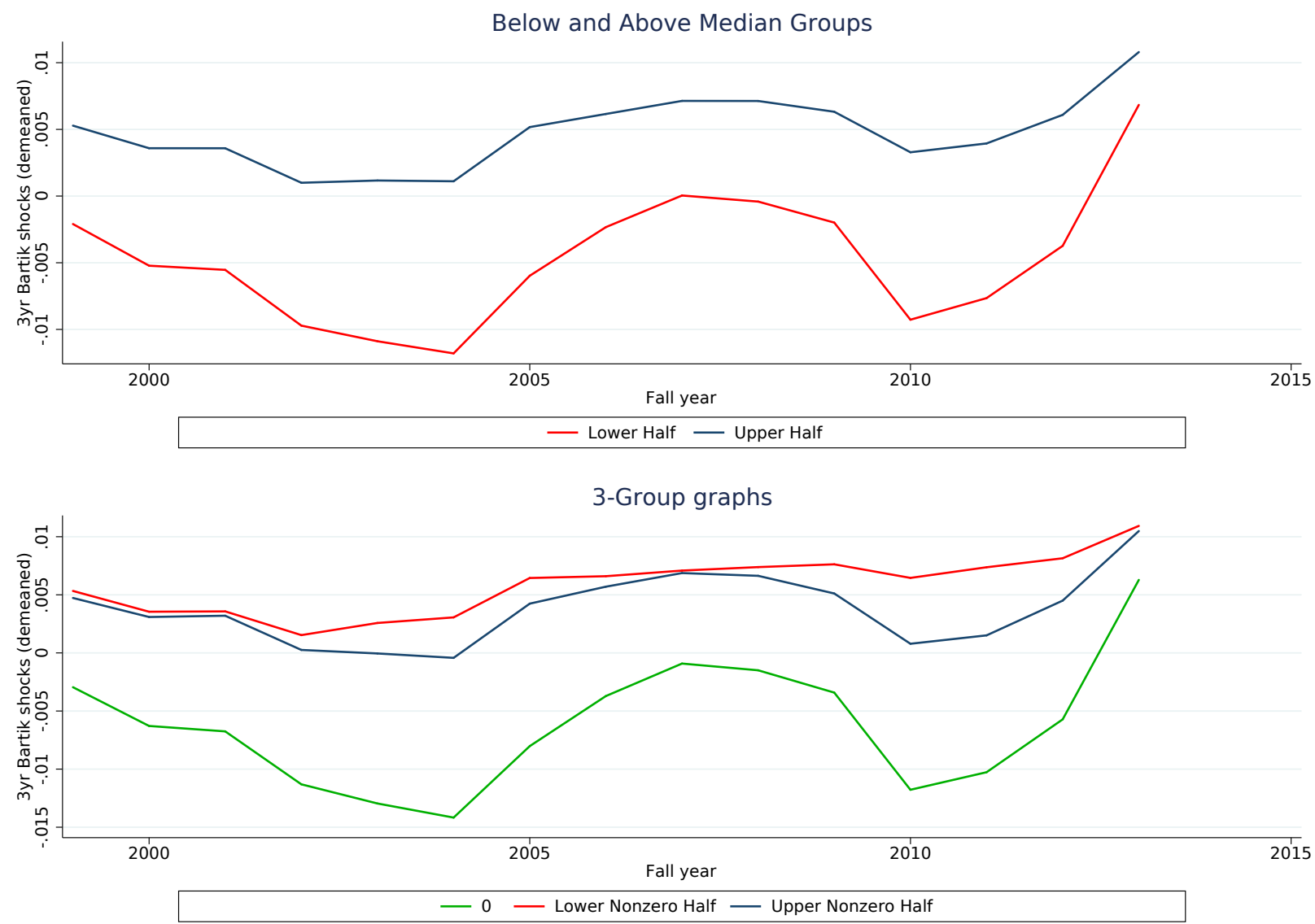

The top panel of this figure plots trends over time in 3-year rolling predicted labor demand changes that are residual to the CBSA-specific mean for CBSAs that have above and below median 2000 for-profit shares. In the bottom panel, we plot demeaned 3-year rolling predicted labor demand changes for CBSAs with no for-profits and for CBSAs with above and below median for-profit shares among those with any for-profit institutions. 
Figure A-2a: Pre-2000 Trends by For-Profit Supply, Below and Above Median
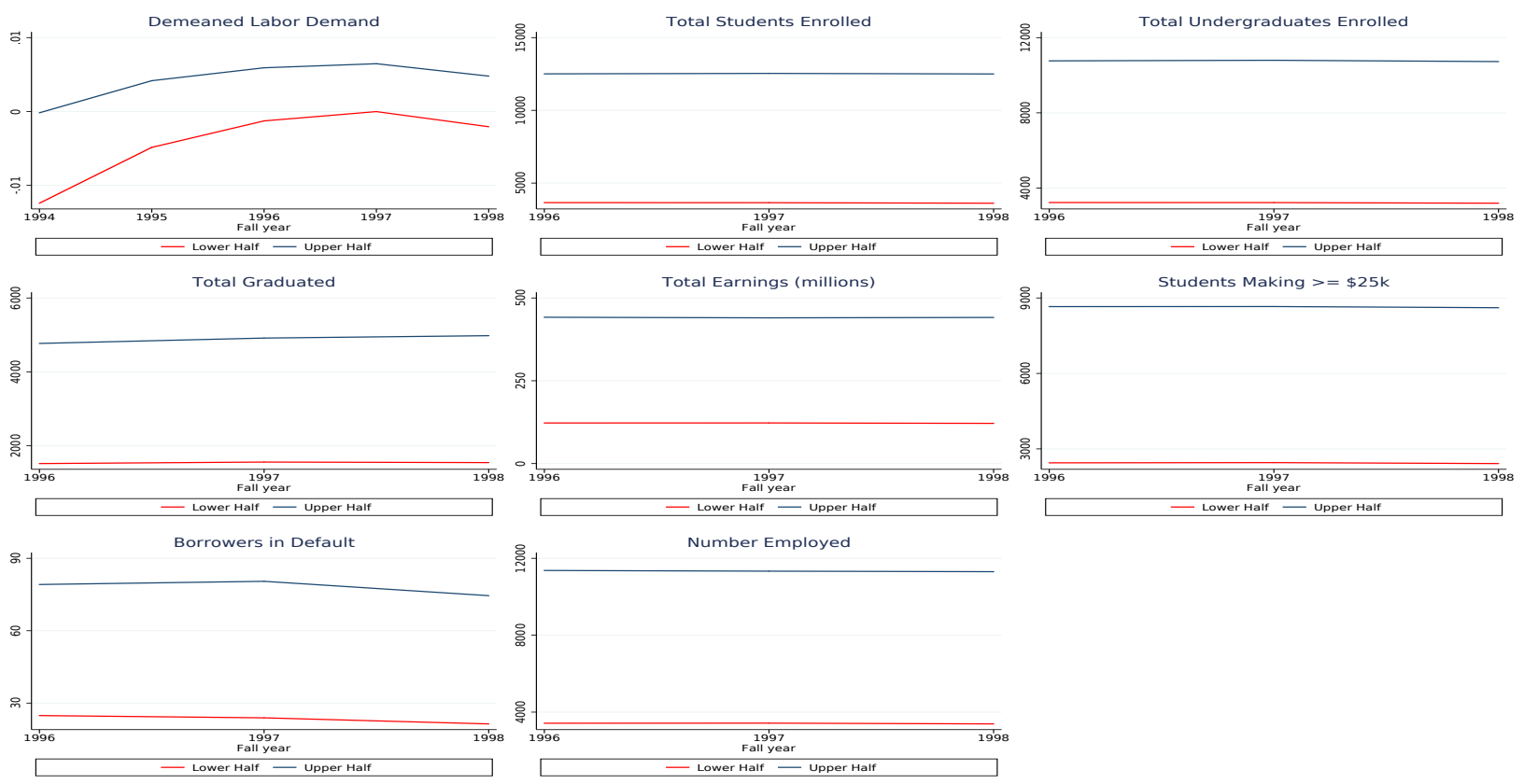

Figure A-2b: Pre-2000 Trends by For-Profit Supply, Three Groups
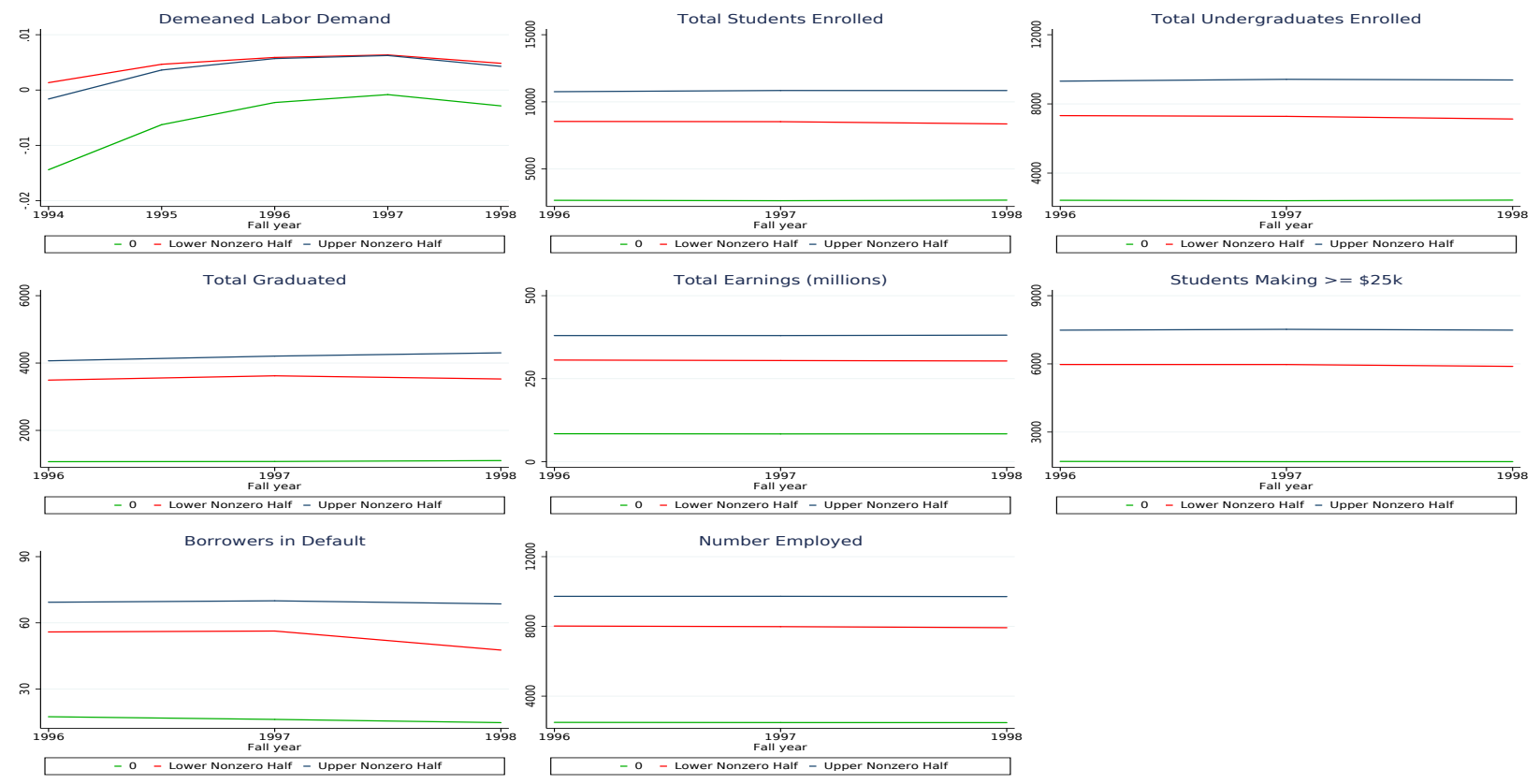

These figures show demeaned (by CBSA) labor demand trends, enrollment, and outcome variables in the pre-2000 period for all institutions together without splitting into 2-year and 4-year schools. Figure A-2 shows trends in each variable over time for CBSAs below and above the median in the baseline for-profit supply distribution. Figure A-3 shows trends in each variable over time for CBSAs in 3 groups: the group with 0 for-profit supply, and below and above median groups in the non-zero baseline for-profit supply distribution. 
Figure A-3a: Pre-2000 Educational and Labor Market Outcome Trends by Labor Demand, Below and Above Median
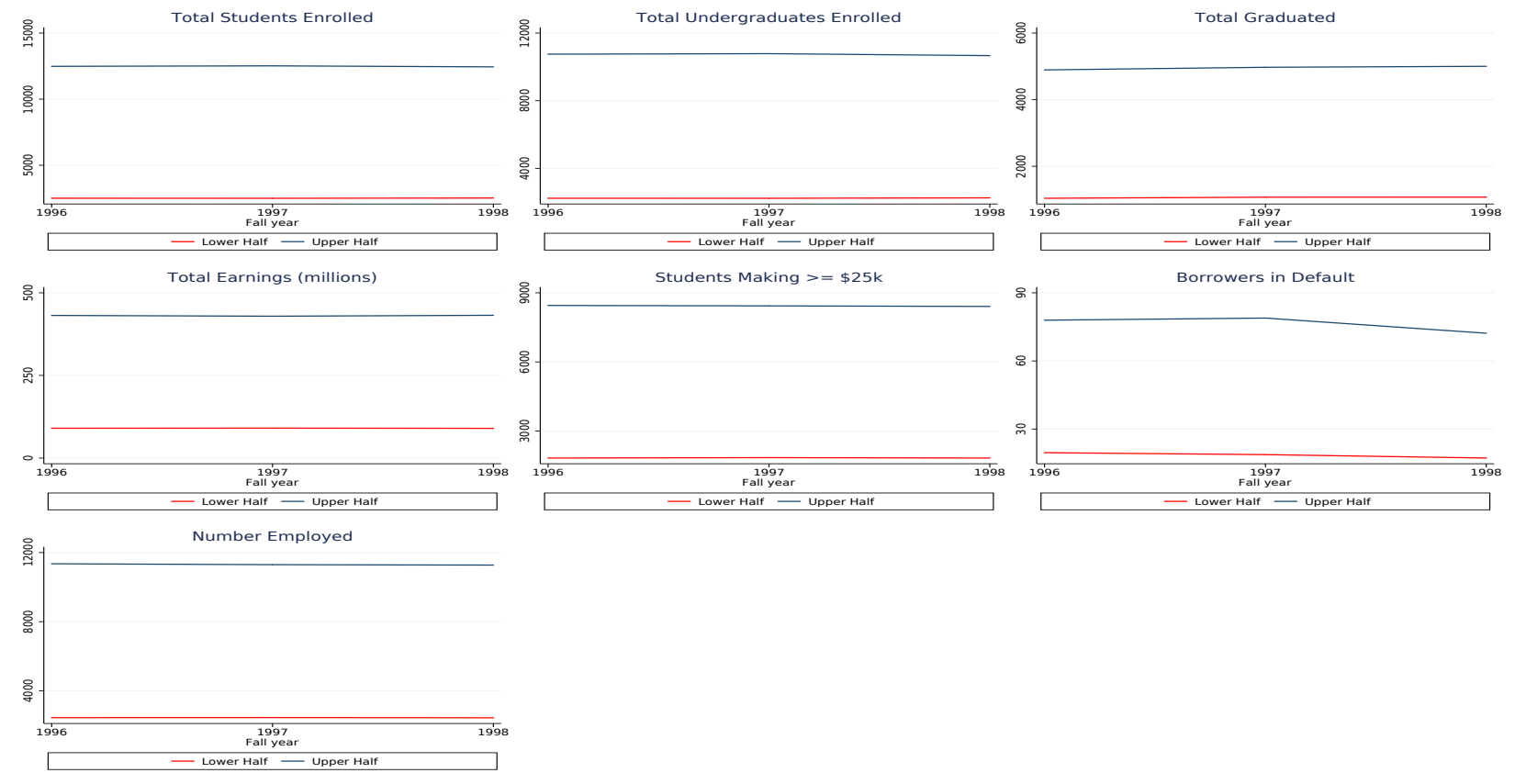

Figure A-3b: Pre-2000 Educational and Labor Market Outcome Trends by Labor Demand, Below and Above Zero
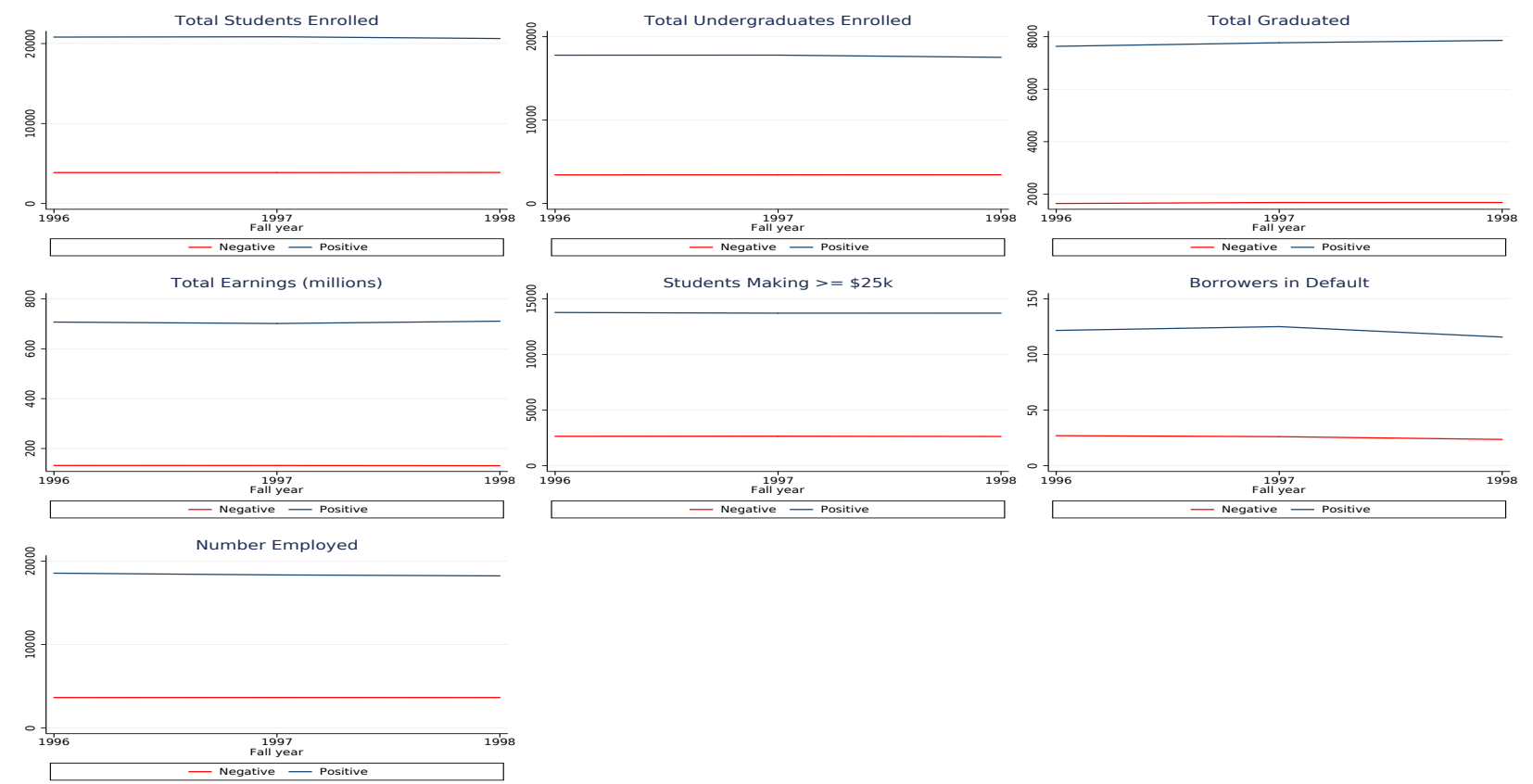

These figures show enrollment and outcome variables in the pre-2000 period for all institutions together without splitting into 2-year and 4-year schools. Figure A-4 shows trends in each variable over time for CBSAs below and above the median in predicted labor demand as measured in 1998 ( $\left.\hat{\eta}_{1998}\right)$. Figure A-5 shows trends in each variable over time for CBSAs with negative and positive predicted labor demand in 1998. 
Figure A-4: Pre-2000 Trends in Educational and Labor Market Outcomes by Labor Demand $\mathrm{x}$ For-Profit Supply, Below and Above Zero
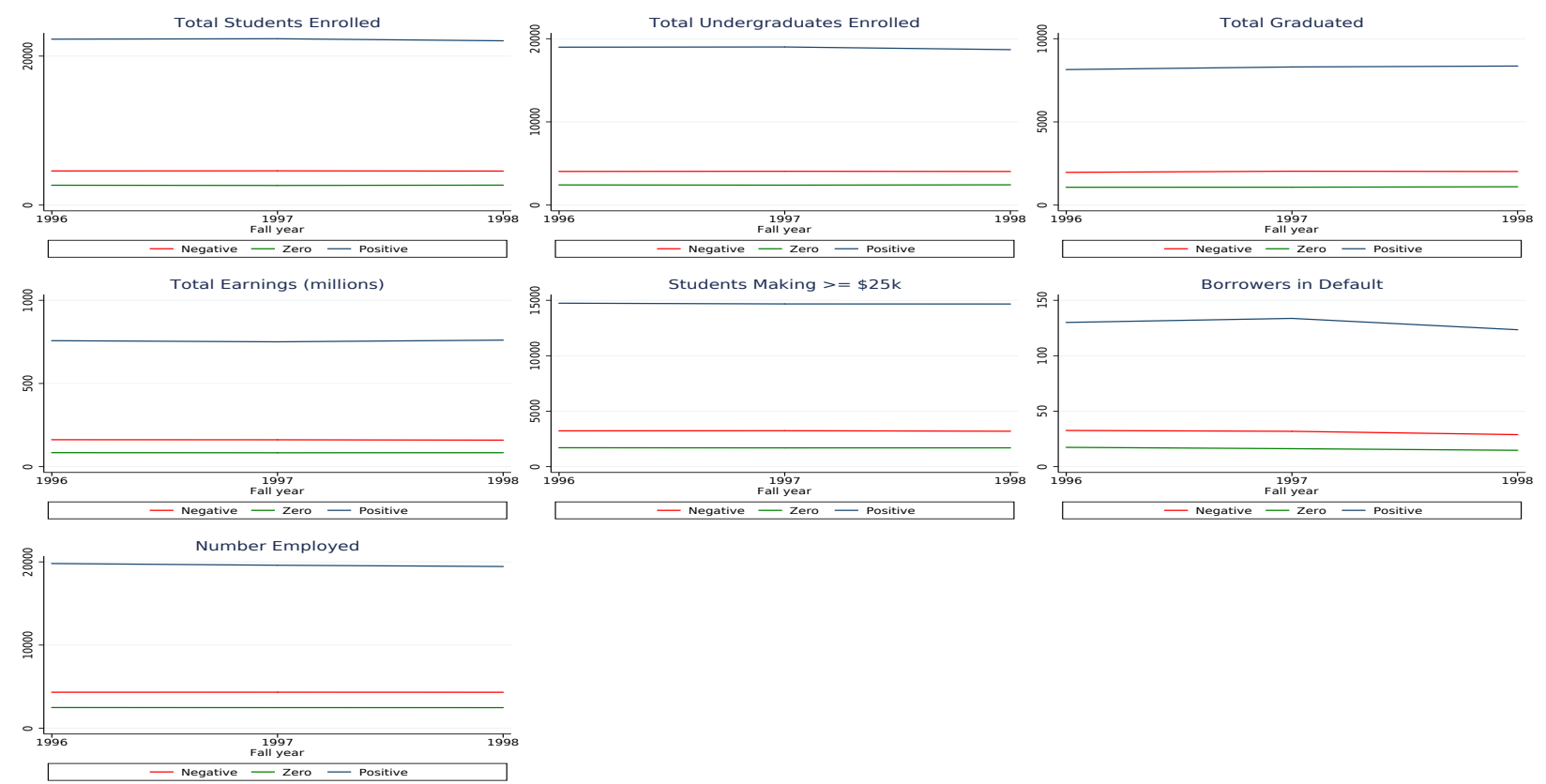

The figure shows pre-2000 enrollment and outcome variable trends for all institutions together without splitting into 2-year and 4-year schools. The trends in each variable over time for CBSAs with negative and positive labor demand interacted with for-profit supply as measured in 1998 ( $\hat{\eta}_{1998} *$ Supply) are shown. 


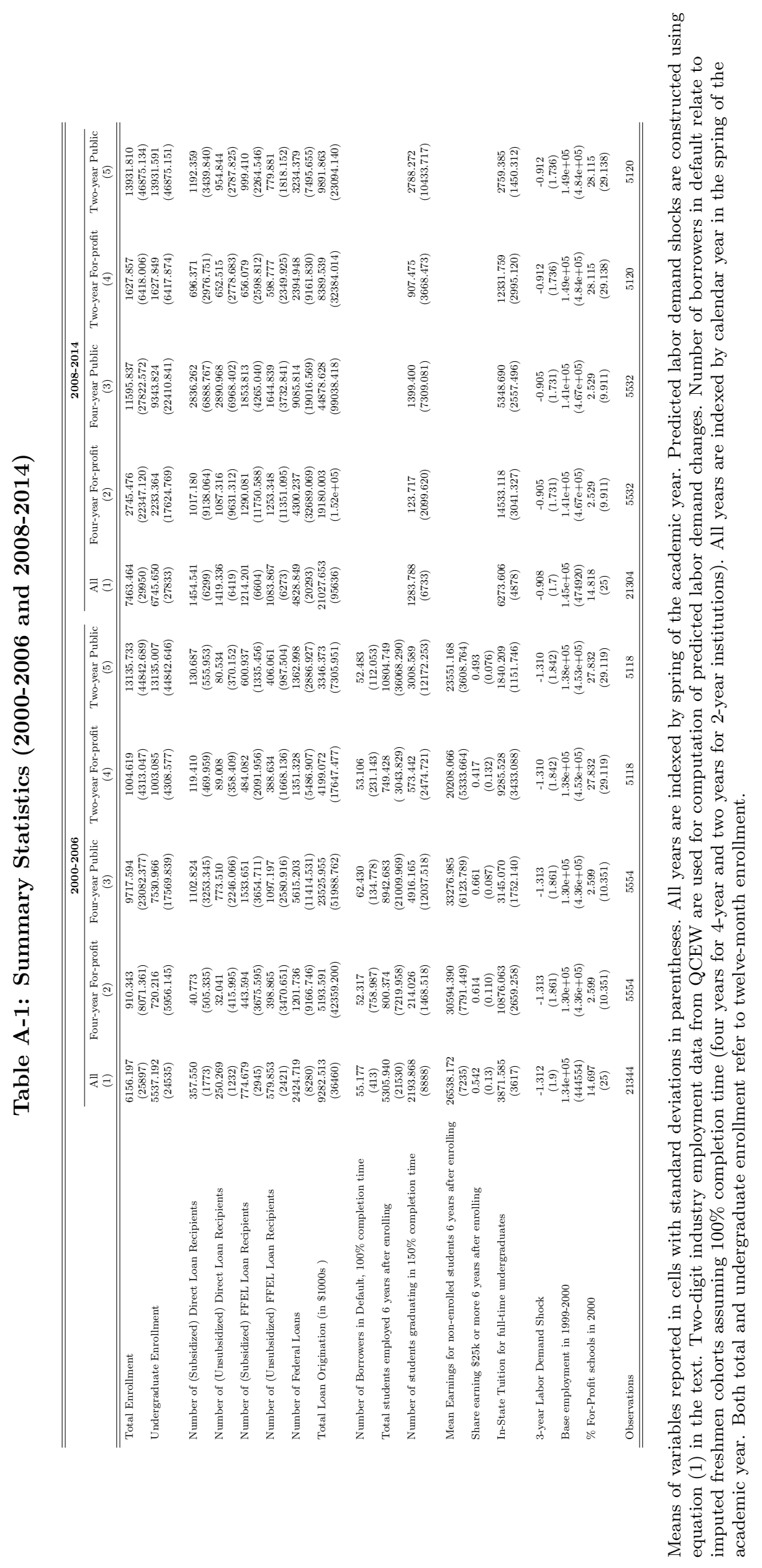


Table A-2: Summary Statistics: Student Composition (2000-2014)

\begin{tabular}{|c|c|c|c|c|c|}
\hline & $\begin{array}{l}\text { All } \\
(1)\end{array}$ & $\begin{array}{c}\text { Four-year } \\
\text { For-profit } \\
\quad(2)\end{array}$ & $\begin{array}{c}\text { Four-year } \\
\text { Public } \\
(3)\end{array}$ & $\begin{array}{c}\text { Two-year } \\
\text { For-profit } \\
\quad(4)\end{array}$ & $\begin{array}{c}\text { Two-year } \\
\text { Public } \\
\text { (5) }\end{array}$ \\
\hline \% Undergraduates Black & $\begin{array}{c}13.490 \\
(16.706)\end{array}$ & $\begin{array}{c}19.343 \\
(17.679)\end{array}$ & $\begin{array}{c}10.974 \\
(16.044)\end{array}$ & $\begin{array}{c}16.457 \\
(19.418)\end{array}$ & $\begin{array}{c}11.803 \\
(14.007)\end{array}$ \\
\hline \% Undergraduates Hispanic & $\begin{array}{c}8.098 \\
(14.115)\end{array}$ & $\begin{array}{c}8.456 \\
(11.260)\end{array}$ & $\begin{array}{c}7.172 \\
(13.132)\end{array}$ & $\begin{array}{c}9.423 \\
(16.378)\end{array}$ & $\begin{array}{c}7.661 \\
(13.374)\end{array}$ \\
\hline \% Undergraduates White & $\begin{array}{c}68.239 \\
(22.663)\end{array}$ & $\begin{array}{c}51.820 \\
(23.101)\end{array}$ & $\begin{array}{c}69.623 \\
(20.893)\end{array}$ & $\begin{array}{c}67.019 \\
(25.625)\end{array}$ & $\begin{array}{c}71.457 \\
(19.761)\end{array}$ \\
\hline$\%$ Undergraduates Female & $\begin{array}{c}65.347 \\
(17.204)\end{array}$ & $\begin{array}{c}57.047 \\
(17.219)\end{array}$ & $\begin{array}{l}55.698 \\
(7.460)\end{array}$ & $\begin{array}{c}83.813 \\
(17.143)\end{array}$ & $\begin{array}{c}59.816 \\
(10.084)\end{array}$ \\
\hline$\%$ Undergraduates Over 25 & $\begin{array}{c}31.296 \\
(20.408)\end{array}$ & $\begin{array}{c}50.109 \\
(25.874)\end{array}$ & $\begin{array}{c}20.531 \\
(13.567)\end{array}$ & $\begin{array}{c}29.500 \\
(21.564)\end{array}$ & $\begin{array}{c}35.692 \\
(17.742)\end{array}$ \\
\hline \% Undergraduates Receiving Pell grant & $\begin{array}{c}48.013 \\
(20.046)\end{array}$ & $\begin{array}{c}62.454 \\
(16.829)\end{array}$ & $\begin{array}{c}34.988 \\
(12.354)\end{array}$ & $\begin{array}{c}64.438 \\
(17.053)\end{array}$ & $\begin{array}{c}40.776 \\
(16.169)\end{array}$ \\
\hline \% Undergraduates Receiving Federal Loans & $\begin{array}{c}46.210 \\
(27.394)\end{array}$ & $\begin{array}{c}75.793 \\
(15.370)\end{array}$ & $\begin{array}{c}50.597 \\
(15.424)\end{array}$ & $\begin{array}{c}61.824 \\
(23.943)\end{array}$ & $\begin{array}{c}24.094 \\
(21.201)\end{array}$ \\
\hline \% Undergraduates Sending FAFSA to 1 College & $\begin{array}{c}74.534 \\
(13.360)\end{array}$ & $\begin{array}{l}80.828 \\
(9.080)\end{array}$ & $\begin{array}{c}59.156 \\
(10.006)\end{array}$ & $\begin{array}{c}84.505 \\
(10.226)\end{array}$ & $\begin{array}{l}76.012 \\
(8.501)\end{array}$ \\
\hline$\%$ Undergraduates Sending FAFSA to 2 Colleges & $\begin{array}{l}15.930 \\
(7.663)\end{array}$ & $\begin{array}{l}13.263 \\
(7.228)\end{array}$ & $\begin{array}{l}20.996 \\
(4.911)\end{array}$ & $\begin{array}{l}12.620 \\
(9.503)\end{array}$ & $\begin{array}{l}15.550 \\
(5.895)\end{array}$ \\
\hline$\%$ Undergraduates Sending FAFSA to 3 Colleges & $\begin{array}{l}4.099 \\
(2.890)\end{array}$ & $\begin{array}{c}2.379 \\
(1.604)\end{array}$ & $\begin{array}{l}7.524 \\
(2.343)\end{array}$ & $\begin{array}{l}1.612 \\
(1.476)\end{array}$ & $\begin{array}{c}3.999 \\
(1.852)\end{array}$ \\
\hline$\%$ Undergraduates Sending FAFSA to 4 Colleges & $\begin{array}{c}2.049 \\
(1.973)\end{array}$ & $\begin{array}{c}1.162 \\
(1.159)\end{array}$ & $\begin{array}{l}4.403 \\
(2.105)\end{array}$ & $\begin{array}{c}0.495 \\
(0.675)\end{array}$ & $\begin{array}{l}1.830 \\
(1.073)\end{array}$ \\
\hline$\%$ Undergraduates Sending FAFSA to 5 Colleges & $\begin{array}{c}3.390 \\
(4.225)\end{array}$ & $\begin{array}{c}2.349 \\
(2.510)\end{array}$ & $\begin{array}{l}7.917 \\
(5.837)\end{array}$ & $\begin{array}{c}0.741 \\
(1.097)\end{array}$ & $\begin{array}{c}2.639 \\
(1.840)\end{array}$ \\
\hline$\%$ Parents with HS Diploma & $\begin{array}{c}36.661 \\
(17.849)\end{array}$ & $\begin{array}{c}16.318 \\
(16.174)\end{array}$ & $\begin{array}{c}33.439 \\
(12.423)\end{array}$ & $\begin{array}{c}34.213 \\
(20.300)\end{array}$ & $\begin{array}{c}44.652 \\
(14.417)\end{array}$ \\
\hline$\%$ Parents with MS & $\begin{array}{c}4.386 \\
(4.120)\end{array}$ & $\begin{array}{c}1.993 \\
(2.435)\end{array}$ & $\begin{array}{l}2.573 \\
(2.477)\end{array}$ & $\begin{array}{c}4.574 \\
(4.664)\end{array}$ & $\begin{array}{c}5.895 \\
(4.142)\end{array}$ \\
\hline \% Parents with College Degree & $\begin{array}{c}39.978 \\
(21.278)\end{array}$ & $\begin{array}{c}17.895 \\
(17.736)\end{array}$ & $\begin{array}{c}56.763 \\
(22.197)\end{array}$ & $\begin{array}{c}28.500 \\
(16.824)\end{array}$ & $\begin{array}{c}42.080 \\
(14.115)\end{array}$ \\
\hline Average Family Income & $\begin{array}{c}37420.04 \\
(17741.83)\end{array}$ & $\begin{array}{c}43060.09 \\
(1661.96)\end{array}$ & $\begin{array}{c}59564.69 \\
(16787.21)\end{array}$ & $\begin{array}{c}27826.09 \\
(10059.62)\end{array}$ & $\begin{array}{l}29848.79 \\
(9365.87)\end{array}$ \\
\hline Average SAT score & $\begin{array}{l}1028.490 \\
(94.244)\end{array}$ & $\begin{array}{c}1010.418 \\
(101.712)\end{array}$ & $\begin{array}{l}1036.884 \\
(90.246)\end{array}$ & $\begin{array}{c}977.352 \\
(81.539)\end{array}$ & $\begin{array}{l}904.709 \\
(59.776)\end{array}$ \\
\hline$\%$ Arts degrees & $\begin{array}{c}36.157 \\
(26.645)\end{array}$ & $\begin{array}{c}40.771 \\
(26.099)\end{array}$ & $\begin{array}{c}60.632 \\
(13.915)\end{array}$ & $\begin{array}{c}8.339 \\
(15.870)\end{array}$ & $\begin{array}{c}39.950 \\
(20.451)\end{array}$ \\
\hline$\%$ STEM degrees & $\begin{array}{c}35.202 \\
(23.304)\end{array}$ & $\begin{array}{c}43.619 \\
(27.021)\end{array}$ & $\begin{array}{c}31.286 \\
(12.572)\end{array}$ & $\begin{array}{c}29.996 \\
(31.796)\end{array}$ & $\begin{array}{c}39.752 \\
(18.637)\end{array}$ \\
\hline$\%$ Vocational degrees & $\begin{array}{c}27.572 \\
(30.857)\end{array}$ & $\begin{array}{c}9.481 \\
(12.366)\end{array}$ & $\begin{array}{l}7.684 \\
(6.168)\end{array}$ & $\begin{array}{c}60.083 \\
(38.150)\end{array}$ & $\begin{array}{c}20.168 \\
(13.849)\end{array}$ \\
\hline \% Associates Degrees & $\begin{array}{c}30.425 \\
(32.391)\end{array}$ & $\begin{array}{c}42.771 \\
(29.163)\end{array}$ & $\begin{array}{c}9.414 \\
(19.431)\end{array}$ & $\begin{array}{c}13.758 \\
(23.670)\end{array}$ & $\begin{array}{c}53.151 \\
(28.947)\end{array}$ \\
\hline \% Bachelors Degrees & $\begin{array}{c}27.630 \\
(34.403)\end{array}$ & $\begin{array}{c}28.153 \\
(21.751)\end{array}$ & $\begin{array}{c}68.203 \\
(19.470)\end{array}$ & $\begin{array}{c}0.005 \\
(0.189)\end{array}$ & $\begin{array}{c}0.001 \\
(0.025)\end{array}$ \\
\hline$\%$ Certificates & $\begin{array}{c}44.126 \\
(39.358)\end{array}$ & $\begin{array}{c}10.531 \\
(16.136)\end{array}$ & $\begin{array}{l}1.872 \\
(5.978)\end{array}$ & $\begin{array}{c}86.237 \\
(23.680)\end{array}$ & $\begin{array}{c}46.848 \\
(28.947)\end{array}$ \\
\hline Observations & 47504 & 11876 & 11876 & 11876 & 11876 \\
\hline
\end{tabular}

Means of variables reported in cells, with standard deviations in parentheses. \% tabulations range from 0-100. 
Table A-3: Summary Statistics: CBSA-level Variables (2000-2014)

\begin{tabular}{lc}
\hline \hline Population Count (1000s) & 344.531 \\
& $(1093.869)$ \\
Percentage Female & 0.506 \\
& $(0.014)$ \\
Percentage White & 0.850 \\
& $(0.140)$ \\
Percentage Black & 0.100 \\
Percentage American Indian & $(0.131)$ \\
Percentage Asian & 0.015 \\
& $(0.045)$ \\
Percentage Two or more races & 0.019 \\
& $0.038)$ \\
Percentage Hispanic & 0.017 \\
Percentage Age 0-19 years & $0.019)$ \\
Percentage Age 20-29 years & 0.092 \\
Percentage Age 30-39 years & $0.139)$ \\
Percentage Age 40+ years & 0.139 \\
Poverty Rate & 0.126 \\
& $0.015)$ \\
Observations & $(0.056)$ \\
\hline \hline
\end{tabular}

Means of variables reported in cells, with standard deviations in parentheses. Percentage and rate tabulations range from 0-1. 
Table A-4: OLS Estimates of the Effect of For-profit Attendance on the Number and Volume of Student Loan Originations and Defaults

\begin{tabular}{|c|c|c|c|c|c|c|c|c|}
\hline & \multicolumn{8}{|c|}{ Panel A: Number of Loans } \\
\hline & \multicolumn{4}{|c|}{ 4-year Schools } & \multicolumn{4}{|c|}{ 2-year Schools } \\
\hline & (1) & $(2)$ & $(3)$ & $(4)$ & $(5)$ & $(6)$ & $(7)$ & $(8)$ \\
\hline \multirow[t]{2}{*}{ Enroll } & $0.528^{* * *}$ & $0.530^{* * *}$ & $0.529^{* * *}$ & $0.530^{* * *}$ & $0.044^{* * *}$ & $0.056^{* * *}$ & $0.043^{* * *}$ & $0.054^{* * *}$ \\
\hline & $(0.003)$ & $(0.003)$ & $(0.003)$ & $(0.003)$ & $(0.001)$ & $(0.001)$ & $(0.001)$ & $(0.001)$ \\
\hline \multirow[t]{2}{*}{ Enroll*For-profit } & $0.818^{* * *}$ & $0.821^{* * *}$ & $0.817^{* * *}$ & $0.820 * * *$ & $1.043^{* * *}$ & $1.097 * * *$ & $1.032^{* * *}$ & $1.086^{* * *}$ \\
\hline & $(0.004)$ & $(0.004)$ & $(0.004)$ & $(0.004)$ & $(0.010)$ & $(0.010)$ & $(0.010)$ & $(0.010)$ \\
\hline Time Fixed Effects & Year & Year & State* $^{*}$ Year & State $^{*}$ Year & Year & Year & State*Year & State*Year \\
\hline State*FP \& Year*FP & No & Yes & No & Yes & No & Yes & No & Yes \\
\hline \multirow[t]{4}{*}{ Observations } & 23752 & 23752 & 23752 & 23752 & 21936 & 21936 & 21936 & 21936 \\
\hline & \multicolumn{8}{|c|}{ Panel B: Loan Origination Amount (\$) } \\
\hline & \multicolumn{4}{|c|}{ 4-year Schools } & \multicolumn{4}{|c|}{ 2-year Schools } \\
\hline & $(1)$ & $(2)$ & $(3)$ & (4) & $(5)$ & $(6)$ & $(7)$ & $(8)$ \\
\hline \multirow[t]{2}{*}{ Enroll } & $2664.60^{* * *}$ & $2680.00^{* * *}$ & $2672.70^{* * *}$ & $2688.70^{* * *}$ & $129.85^{* * *}$ & $166.81^{* * *}$ & $124.27^{* * *}$ & $160.92^{* * *}$ \\
\hline & $(13.96)$ & $(14.03)$ & $(13.90)$ & $(13.95)$ & $(4.18)$ & $(4.29)$ & $(4.21)$ & $(4.32)$ \\
\hline \multirow[t]{2}{*}{ Enroll*For-profit } & $3484.00^{* * *}$ & $3500.80^{* * *}$ & $3475.50 * * *$ & $3492.20 * * *$ & $3755.00^{* * *}$ & $3921.00^{* * *}$ & $3715.90^{* * *}$ & $3881.30^{* * *}$ \\
\hline & $(20.18)$ & $(20.34)$ & $(20.19)$ & $(20.33)$ & $(31.47)$ & $(31.23)$ & $(31.66)$ & $(31.41)$ \\
\hline Time Fixed Effects & Year & Year & State*Year & State*Year & Year & Year & State*Year & State*Year \\
\hline State*FP \& Year*FP & No & Yes & No & Yes & No & Yes & No & Yes \\
\hline \multirow[t]{4}{*}{ Observations } & 23752 & 23752 & 23752 & 23752 & 21936 & 21936 & 21936 & 21936 \\
\hline & \multicolumn{8}{|c|}{ Panel C: Number of Borrowers in Default (100\%) } \\
\hline & \multicolumn{4}{|c|}{ 4-year Schools } & \multicolumn{4}{|c|}{ 2-year Schools } \\
\hline & $(1)$ & $(2)$ & $(3)$ & $(4)$ & $(5)$ & $(6)$ & $(7)$ & $(8)$ \\
\hline \multirow[t]{2}{*}{$\overline{\overline{\text { Enroll }}}$} & $0.004^{* * *}$ & $0.003^{* * *}$ & $0.004^{* * *}$ & $0.003^{* * *}$ & $0.001^{* * *}$ & $0.001^{* * *}$ & $0.001^{* * *}$ & $0.001^{* * *}$ \\
\hline & $(0.000)$ & $(0.000)$ & $(0.000)$ & $(0.000)$ & $(0.000)$ & $(0.000)$ & $(0.000)$ & $(0.000)$ \\
\hline \multirow[t]{2}{*}{ Enroll*For-profit } & $0.023^{* * *}$ & $0.022^{* * *}$ & $0.024^{* * *}$ & $0.023^{* * *}$ & $0.041^{* * *}$ & $0.043^{* * *}$ & $0.040^{* * *}$ & $0.042^{* * *}$ \\
\hline & $(0.001)$ & $(0.001)$ & $(0.001)$ & $(0.001)$ & $(0.001)$ & $(0.001)$ & $(0.001)$ & $(0.001)$ \\
\hline Time Fixed Effects & Year & Year & State*Year & State*Year $^{*}$ & Year & Year & State*Year & State*Year \\
\hline State*FP \& Year*FP & No & Yes & No & Yes & No & Yes & No & Yes \\
\hline Observations & 15463 & 15463 & 15463 & 15463 & 14616 & 14616 & 14616 & 14616 \\
\hline
\end{tabular}

Authors estimates of equation (5) in the text by OLS using for-profit and public institutions. The enrollment measure is 12-month total enrollment. Enrollment and outcomes are aggregated by CBSA, institution-type (public or for-profit) and level (two-year or four-year). Robust standard errors adjusted for clustering by CBSA are in parentheses: *,**,*** indicate significance at the 10, 5 , and 1 percent level, respectively. All regressions include the following CBSA-year level variables as controls: base-year $(t-3)$ employment, gender composition (\%female), racial composition (\%black, \%Hispanic, \%American India, \%Asian, \% Two or more races), age composition (\%20-29, \%30-39, \%40 or over), \%poverty, and total population. All regressions also include CBSA and year fixed effects. Even columns include state-for profit and year-for profit fixed effects, while columns (3)-(4) and (7)-(8) include state-by-year fixed effects. Two year estimates include two-year and less than two year institutions and exclude the 65 CBSAs that only have a for-profit college in the base year. 
Table A-5: OLS Estimates of the Effect of For-profit Attendance on Student Borrowing, by Loan Type

\begin{tabular}{|c|c|c|c|c|c|c|c|c|}
\hline & \multicolumn{8}{|c|}{ Panel A: Number Recipients: Direct Subsidized Loans } \\
\hline & \multicolumn{4}{|c|}{ 4-year Schools } & \multicolumn{4}{|c|}{ 2-year Schools } \\
\hline & (1) & $(2)$ & $(3)$ & (4) & $(5)$ & (6) & (7) & (8) \\
\hline$\overline{\overline{\text { Enroll }}}$ & $0.168^{* * *}$ & $0.168^{* * *}$ & $0.168^{* * *}$ & "0.168*** & $0.026^{* * *}$ & "0.031*** & $0.025^{* * *}$ & (0.030*** \\
\hline Enroll*For-profit & $\begin{array}{c}0.102^{* * *} \\
(0.003)\end{array}$ & $\begin{array}{c}0.107^{* * *} \\
(0.003)\end{array}$ & $\begin{array}{c}0.101^{* * *} \\
(0.003)\end{array}$ & $\begin{array}{c}0.106^{* * *} \\
(0.003)\end{array}$ & $\begin{array}{c}0.277^{* * *} \\
(0.005)\end{array}$ & $\begin{array}{c}0.300^{* * *} \\
(0.006)\end{array}$ & $\begin{array}{c}0.273^{* * *} \\
(0.005)\end{array}$ & $\begin{array}{c}0.296^{* * *} \\
(0.006)\end{array}$ \\
\hline Time Fixed Effect Type & Year & Year & State*Year & State*Year & Year & Year & State*Year & State*Year \\
\hline State*FP \& Year*FP & No & Yes & No & Yes & No & Yes & No & Yes \\
\hline \multirow[t]{4}{*}{ Observations } & 23752 & 23752 & 23752 & 23752 & 21936 & 21936 & 21936 & 21936 \\
\hline & \multicolumn{8}{|c|}{ Panel B: Number Recipients: Direct Unsubsidized Loans } \\
\hline & \multicolumn{4}{|c|}{ 4-year Schools } & \multicolumn{4}{|c|}{ 2-year Schools } \\
\hline & (1) & $(2)$ & $(3)$ & (4) & $(5)$ & $(6)$ & (7) & $(8)$ \\
\hline Enroll & $\begin{array}{c}0.149^{* * *} \\
(0.002)\end{array}$ & $\begin{array}{c}0.149^{* * *} \\
(0.002)\end{array}$ & $\begin{array}{c}0.149^{* * *} \\
(0.002)\end{array}$ & $\begin{array}{c}0.150^{* * *} \\
(0.002)\end{array}$ & $\begin{array}{c}0.021^{* * *} \\
(0.001)\end{array}$ & $\begin{array}{c}0.026^{* * *} \\
(0.001)\end{array}$ & $\begin{array}{c}0.021^{* * *} \\
(0.001)\end{array}$ & $\begin{array}{c}0.025^{* * *} \\
(0.001)\end{array}$ \\
\hline Enroll*For-profit & $\begin{array}{c}0.131^{* * *} \\
(0.003)\end{array}$ & $\begin{array}{c}0.136^{* * *} \\
(0.003)\end{array}$ & $\begin{array}{c}0.131^{* * *} * \\
(0.003)\end{array}$ & $\begin{array}{c}0.136^{* * *} \\
(0.003)\end{array}$ & $\begin{array}{c}0.270 * * * \\
(0.005)\end{array}$ & $\begin{array}{c}0.291^{* * *} \\
(0.005)\end{array}$ & $\begin{array}{c}0.266^{* * *} \\
(0.005)\end{array}$ & $\begin{array}{c}0.287^{* * * *} \\
(0.005)\end{array}$ \\
\hline Time Fixed Effects & Year & Year & State*Year & State*Year & Year & Year & State*Year & State*Year \\
\hline State*FP \& Year*FP & No & Yes & No & Yes & No & Yes & No & Yes \\
\hline \multirow[t]{4}{*}{ Observations } & 23752 & 23752 & 23752 & 23752 & 21936 & 21936 & 21936 & 21936 \\
\hline & \multicolumn{8}{|c|}{ 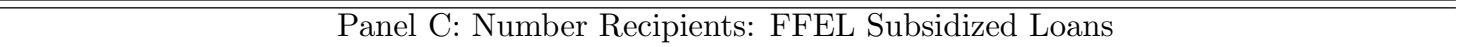 } \\
\hline & \multicolumn{4}{|c|}{ 4-year Schools } & \multicolumn{4}{|c|}{ 2-year Schools } \\
\hline & (1) & $(2)$ & $(3)$ & (4) & $(5)$ & (6) & (7) & $(8)$ \\
\hline Enroll & $\begin{array}{c}0.127^{* * *} \\
(0.001)\end{array}$ & $\begin{array}{c}0.129^{* * *} \\
(0.001)\end{array}$ & $\begin{array}{c}0.127^{* * *} \\
(0.001)\end{array}$ & $\begin{array}{c}0.129^{* * *} \\
(0.001)\end{array}$ & $\begin{array}{c}0.003^{* * *} \\
(0.000)\end{array}$ & $\begin{array}{c}0.005^{* * *} \\
(0.000)\end{array}$ & $\begin{array}{c}0.003^{* * *} \\
(0.000)\end{array}$ & $\begin{array}{c}0.004^{* * *} \\
(0.000)\end{array}$ \\
\hline Enroll*For-profit & $\begin{array}{c}0.388^{* * *} \\
(0.002)\end{array}$ & $\begin{array}{c}0.386^{* * *} \\
(0.002)\end{array}$ & $\begin{array}{c}0.388^{* * *} * \\
(0.002)\end{array}$ & $\begin{array}{c}0.386^{* * *} \\
(0.002)\end{array}$ & $\begin{array}{c}0.264^{* * *} \\
(0.004)\end{array}$ & $\begin{array}{c}0.275^{* * *} \\
(0.004)\end{array}$ & $\begin{array}{c}0.261^{* * *} \\
(0.004)\end{array}$ & $\begin{array}{c}0.272^{* * *} \\
(0.004)\end{array}$ \\
\hline Time Fixed Effects & Year & Year & State*Year & State*Year & Year & Year & State*Year & State*Year \\
\hline State*FP \& Year*FP & No & Yes & No & Yes & No & Yes & No & Yes \\
\hline \multirow[t]{4}{*}{ Observations } & 17426 & 17426 & 17426 & 17426 & 16082 & 16082 & 16082 & 16082 \\
\hline & \multicolumn{8}{|c|}{ 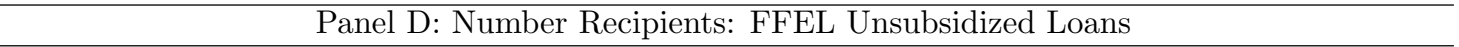 } \\
\hline & \multicolumn{4}{|c|}{ 4-year Schools } & \multicolumn{4}{|c|}{ 2-year Schools } \\
\hline & (1) & $(2)$ & (3) & (4) & $(5)$ & (6) & (7) & (8) \\
\hline Enroll & $\begin{array}{c}0.100^{* * *} \\
(0.001)\end{array}$ & $\begin{array}{c}0.102^{* * *} \\
(0.001)\end{array}$ & $\begin{array}{c}0.100^{* * *} \\
(0.001)\end{array}$ & $\begin{array}{c}0.102^{* * *} \\
(0.001)\end{array}$ & $\begin{array}{c}0.000 \\
(0.000)\end{array}$ & $\begin{array}{c}0.002^{* * *} \\
(0.000)\end{array}$ & $\begin{array}{l}-0.000 \\
(0.000)\end{array}$ & $\begin{array}{c}0.002^{* * *} \\
(0.000)\end{array}$ \\
\hline Enroll*For-profit & $\begin{array}{c}0.396^{* * *} \\
(0.001)\end{array}$ & $\begin{array}{c}0.395^{* * *} \\
(0.001)\end{array}$ & $\begin{array}{c}0.396^{* * * *} \\
(0.001)\end{array}$ & $\begin{array}{c}0.395^{* * *} \\
(0.001)\end{array}$ & $\begin{array}{c}0.227^{* * *} \\
(0.003)\end{array}$ & $\begin{array}{c}0.239^{* * *} \\
(0.003)\end{array}$ & $\begin{array}{c}0.224^{* * *} \\
(0.003)\end{array}$ & $\begin{array}{c}0.236^{* * *} \\
(0.003)\end{array}$ \\
\hline Time Fixed Effects & Year & Year & State*Year & State*Year & Year & Year & State*Year & State*Year \\
\hline State*FP \& Year*FP & No & Yes & No & Yes & No & Yes & No & Yes \\
\hline Observations & 17426 & 17426 & 17426 & 17426 & 16082 & 16082 & 16082 & 16082 \\
\hline
\end{tabular}

Authors estimates of equation (5) in the text by OLS using for-profit and public institutions. The enrollment measure is 12-month total enrollment. Enrollment and outcomes are aggregated by CBSA, institution-type (public or for-profit) and level (two-year or four-year). Robust standard errors adjusted for clustering by CBSA are in parentheses: $*, * *, * * *$ indicate significance at the 10, 5, and 1 percent level, respectively. All regressions include the following CBSA-year level variables as controls: base-year $(t-3)$ employment, gender composition (\%female), racial composition (\%black, \%Hispanic, \%American India, \%Asian, \% Two or more races), age composition (\%20-29, \%30-39, \%40 or over), \%poverty, and total population. All regressions also include CBSA and year fixed effects. Even columns include state-for profit and year-for profit fixed effects, while columns (3)-(4) and (7)-(8) include state-by-year fixed effects. Two year estimates include two-year and less than two year institutions and exclude the 65 CBSAs that only have a for-profit college in the base year. 
Table A-6: OLS Estimates of the Effect of For-profit Attendance on Employment, Earnings, and Graduation

\begin{tabular}{|c|c|c|c|c|}
\hline & \multicolumn{4}{|c|}{ Panel A: Total Graduated, assuming 150\% Completion Time } \\
\hline & \multicolumn{2}{|c|}{ 4-year Schools } & \multicolumn{2}{|c|}{ 2-year Schools } \\
\hline & (1) & $(2)$ & (3) & (4) \\
\hline \multirow[t]{2}{*}{$\overline{\overline{\text { Enroll }}}$} & $0.329^{* * *}$ & $0.328^{* * *}$ & $0.274^{* * *}$ & $0.268^{* * *}$ \\
\hline & $(0.003)$ & $(0.003)$ & $(0.001)$ & $(0.001)$ \\
\hline \multirow[t]{2}{*}{ Enroll*For-profit } & $-0.246^{* * *}$ & $-0.250 * * *$ & $0.750^{* * *}$ & $0.726^{* * *}$ \\
\hline & $(0.004)$ & $(0.004)$ & $(0.009)$ & $(0.009)$ \\
\hline Time Fixed Effects & State*Year & State*Year & State*Year & State*Year \\
\hline State*FP \& Year*FP & No & Yes & No & Yes \\
\hline \multirow[t]{4}{*}{ Observations } & 19022 & 19022 & 17560 & 17560 \\
\hline & \multicolumn{4}{|c|}{ Panel B: Number Employed, 6 years after enrollment } \\
\hline & \multicolumn{2}{|c|}{ 4-year Schools } & \multicolumn{2}{|c|}{ 2-year Schools } \\
\hline & (1) & $(2)$ & (3) & (4) \\
\hline \multirow[t]{2}{*}{$\overline{\text { Enroll }}$} & $0.908^{* * *}$ & $0.908^{* * *}$ & $0.788^{* * *}$ & $0.791^{* * *}$ \\
\hline & $(0.001)$ & $(0.001)$ & $(0.001)$ & $(0.001)$ \\
\hline \multirow[t]{2}{*}{ Enroll*For-profit } & $-0.043^{* * *}$ & $-0.046^{* * *}$ & $-0.337^{* * *}$ & $-0.325^{* * *}$ \\
\hline & $(0.002)$ & $(0.002)$ & $(0.007)$ & $(0.007)$ \\
\hline Time Fixed Effects & State*Year & State*Year & State*Year & State*Year \\
\hline State*FP \& Year*FP & No & Yes & No & Yes \\
\hline \multirow[t]{4}{*}{ Observations } & 9516 & 9516 & 8774 & 8774 \\
\hline & \multicolumn{4}{|c|}{ Panel C: Total Earnings, 6 years after enrollment } \\
\hline & \multicolumn{2}{|c|}{ 4-year Schools } & \multicolumn{2}{|c|}{ 2-year Schools } \\
\hline & (1) & $(2)$ & (3) & (4) \\
\hline \multirow[t]{2}{*}{ Enroll } & $37591.40^{* * *}$ & $37485.30^{* * *}$ & $23900.90^{* * *}$ & $24042.30^{* * *}$ \\
\hline & $(66.97)$ & $(66.74)$ & $(47.55)$ & $(50.62)$ \\
\hline \multirow[t]{2}{*}{ Enroll*For-profit } & -23.15 & -226.55 & $-11743.30^{* * *}$ & $-10920.40^{* * *}$ \\
\hline & $(156.89)$ & $(158.16)$ & $(434.20)$ & $(443.13)$ \\
\hline Time Fixed Effects & State*Year & State*Year & State*Year & State*Year \\
\hline State*FP \& Year*FP & No & Yes & No & Yes \\
\hline \multirow[t]{4}{*}{ Observations } & 9516 & 9516 & 8774 & 8774 \\
\hline & \multicolumn{4}{|c|}{ Panel D: Total Students Making $\$ 25 \mathrm{k}, 6$ years after enrollment } \\
\hline & \multicolumn{2}{|c|}{ 4-year Schools } & \multicolumn{2}{|c|}{ 2-year Schools } \\
\hline & $(1)$ & $(2)$ & $(3)$ & $(4)$ \\
\hline \multirow[t]{2}{*}{ Enroll } & $0.710^{* * *}$ & $0.708^{* * *}$ & $0.505^{* * *}$ & $0.507^{* * *}$ \\
\hline & $(0.001)$ & $(0.001)$ & $(0.001)$ & $(0.001)$ \\
\hline \multirow[t]{2}{*}{ Enroll*For-profit } & $-0.024^{* * *}$ & $-0.027^{* * *}$ & $-0.229^{* * *}$ & $-0.212^{* * *}$ \\
\hline & $(0.002)$ & $(0.002)$ & $(0.009)$ & $(0.009)$ \\
\hline Time Fixed Effects & State*Year & State*Year & State*Year & State*Year \\
\hline State*FP \& Year*FP & No & Yes & No & Yes \\
\hline Observations & 9516 & 9516 & 8774 & 8774 \\
\hline
\end{tabular}

Authors estimates of equation (5) in the text by OLS using for-profit and public institutions. The enrollment measure is 12-month total enrollment. Enrollment and outcomes are aggregated by CBSA, institution-type (public or for-profit) and level (two-year or four-year). Robust standard errors adjusted for clustering by CBSA are in parentheses: ${ }^{*}, * *, * * *$ indicate significance at the 10, 5 , and 1 percent level, respectively. All regressions include the following CBSA-year level variables as controls: base-year $(t-3)$ employment, gender composition (\%female), racial composition (\%black, \%Hispanic, \%American India, \%Asian, \% Two or more races), age composition (\%20-29, \%30-39, \%40 or over), \%poverty, and total population. All regressions also include CBSA and year fixed effects. Even columns include state-for profit and year-for profit fixed effects, while columns (3)-(4) and (7)-(8) include state-by-year fixed effects. Two year estimates include two-year and less than two year institutions and exclude the 65 CBSAs that only have a for-profit college in the base year. 
Table A-7: First Stage Enrollment Estimates Using Base Year \% For Profit Enrollment as Supply Measure

\begin{tabular}{|c|c|c|c|c|c|c|}
\hline \multirow[t]{2}{*}{$\overline{\text { Panel A: } 4 \text { year schools }}$} & \multicolumn{2}{|c|}{$2000-2014$} & \multicolumn{2}{|c|}{$2000-2006$} & \multicolumn{2}{|c|}{$2008-2014$} \\
\hline & (1) & $(2)$ & $(3)$ & $(4)$ & $(5)$ & $(6)$ \\
\hline$\overline{\overline{(2000 \text { For-profit Supply })^{*} \hat{\eta}}}$ & $\begin{array}{l}-139.310 \\
(207.590)\end{array}$ & $\begin{array}{l}-127.050 \\
(188.620)\end{array}$ & $\begin{array}{c}9.254 \\
(88.777)\end{array}$ & $\begin{array}{c}13.594 \\
(83.865)\end{array}$ & $\begin{array}{c}37.402 \\
(25.446)\end{array}$ & $\begin{array}{l}40.709^{*} \\
(23.604)\end{array}$ \\
\hline$(\text { For-profit })^{*}(2000 \text { Supply })^{*} \hat{\eta}$ & $\begin{array}{c}-121.430 \\
(154.310) \\
{[-0.787]}\end{array}$ & $\begin{array}{c}-121.430 \\
(156.660) \\
{[-0.775]}\end{array}$ & $\begin{array}{c}-132.560 \\
(122.200) \\
{[-1.085]}\end{array}$ & $\begin{array}{c}-132.560 \\
(123.900) \\
{[-1.070]}\end{array}$ & $\begin{array}{c}-247.130 * * * \\
(32.499) \\
{[-7.604]}\end{array}$ & $\begin{array}{c}-247.130 * * * \\
(32.948) \\
{[-7.501]}\end{array}$ \\
\hline Time Fixed Effects & Year & State*Year & Year & State*Year & Year & State*Year \\
\hline State*FP \& Year*FP & Yes & Yes & Yes & Yes & Yes & Yes \\
\hline$\overline{\text { Observations }}$ & 23178 & 23178 & 10876 & 10876 & 10952 & 10952 \\
\hline R-squared & 0.220 & 0.230 & 0.261 & 0.264 & 0.219 & 0.224 \\
\hline$P$-value ${ }^{1}$ & 0.332 & 0.316 & 0.225 & 0.221 & 0.000 & 0.000 \\
\hline \multirow[t]{2}{*}{ Panel B: 2 year schools } & \multicolumn{2}{|c|}{$2000-2014$} & \multicolumn{2}{|c|}{$2000-2006$} & \multicolumn{2}{|c|}{$2008-2014$} \\
\hline & $(1)$ & $(2)$ & $(3)$ & $(4)$ & $(5)$ & $(6)$ \\
\hline$\overline{\left(2000 \text { For-profit Supply) }{ }^{*} \hat{\eta}\right.}$ & $\begin{array}{c}7.666 \\
(10.803)\end{array}$ & $\begin{array}{c}5.542 \\
(10.871)\end{array}$ & $\begin{array}{c}18.689 \\
(12.726)\end{array}$ & $\begin{array}{c}16.699 \\
(12.897)\end{array}$ & $\begin{array}{l}-1.847 \\
(6.135)\end{array}$ & $\begin{array}{l}-2.783 \\
(6.323)\end{array}$ \\
\hline$(\text { For-profit })^{*}(2000 \text { Supply })^{*} \hat{\eta}$ & $\begin{array}{l}-18.674 \\
(20.811) \\
{[-0.897]}\end{array}$ & $\begin{array}{l}-18.674 \\
(21.157) \\
{[-0.883]}\end{array}$ & $\begin{array}{l}-40.425 \\
(25.552) \\
{[-1.582]}\end{array}$ & $\begin{array}{l}-40.425 \\
(25.940) \\
{[-1.558]}\end{array}$ & $\begin{array}{c}4.139 \\
(11.667) \\
{[0.355]}\end{array}$ & $\begin{array}{c}4.139 \\
(11.842) \\
{[0.349]}\end{array}$ \\
\hline Time Fixed Effects & Year & State* Year & Year & State*Year & Year & State*Year \\
\hline State*FP \& Year*FP & Yes & Yes & Yes & Yes & Yes & Yes \\
\hline Observations & 21292 & 21292 & 9984 & 9984 & 10072 & 10072 \\
\hline R-squared & 0.203 & 0.206 & 0.210 & 0.211 & 0.195 & 0.197 \\
\hline$P$-value ${ }^{1}$ & 0.100 & 0.163 & 0.121 & 0.017 & 0.896 & 0.824 \\
\hline
\end{tabular}

Authors estimates of equation (4) in the text using for-profit and public institutions. The dependent variable is total 12-month enrollment aggregated by CBSA, sector (public or for-profit) and level (two-year or four-year). Robust standard errors adjusted for clustering by CBSA are in parentheses: *, ${ }^{* *},{ }^{* *}$ indicate significance at the 10,5 , and 1 percent level, respectively. "P-value" shows the p-value of F-tests for joint significance of instruments. Labor demand shocks are proxied by three-year rolling predicted changes as described in the text. Two- digit industry employment data from QCEW are used for computation of labor demand shocks. The supply measure is percentage of enrollment in for-profit institutions at the corresponding level (two-year or four-year) in the CBSA in 2000 or 2007 (for 2008-14 period). All regressions include the following CBSA-year level variables as controls: base-year $(t-3)$ employment, gender composition (\% female), racial composition (\% black, \%Hispanic, \%American Indian, \%Asian, \% Two or more races), age composition (\%20-29, \%30-39, \%40 or over), \%poverty and total population. All regressions also include CBSA and year fixed effects, while even columns include state-by-year fixed effects. Two year estimates include two-year and less than two year institutions and exclude the 65 CBSAs that only have a for-profit college in the base year. 
Table A-8: First Stage Enrollment Estimates, Excluding Selective Institutions

\begin{tabular}{|c|c|c|c|c|c|c|}
\hline \multirow[t]{2}{*}{$\overline{\text { Panel A: } 4 \text { year schools }}$} & \multicolumn{2}{|c|}{$2000-2014$} & \multicolumn{2}{|c|}{$2000-2006$} & \multicolumn{2}{|c|}{$2008-2014$} \\
\hline & (1) & $(2)$ & (3) & (4) & (5) & $(6)$ \\
\hline$\overline{\left(2000 \text { For-profit Supply) }{ }^{*} \hat{\eta}\right.}$ & $\begin{array}{c}13.746 \\
(45.594)\end{array}$ & $\begin{array}{c}26.385 \\
(42.005)\end{array}$ & $\begin{array}{c}40.973 \\
(36.383)\end{array}$ & $\begin{array}{c}47.126 \\
(35.133)\end{array}$ & $\begin{array}{c}87.094^{* * *} \\
(23.894)\end{array}$ & $\begin{array}{c}88.355^{* * * *} \\
(23.892)\end{array}$ \\
\hline$($ For-profit $) *(2000 \text { Supply })^{*} \hat{\eta}$ & $\begin{array}{c}-210.380^{* * *} \\
(59.056) \\
{[-3.562]}\end{array}$ & $\begin{array}{c}-210.380^{* * *} \\
(59.939) \\
{[-3.510]}\end{array}$ & $\begin{array}{c}-150.010^{* * *} \\
(53.245) \\
{[-2.817]}\end{array}$ & $\begin{array}{c}-150.010^{* * *} \\
(53.970) \\
{[-2.779]}\end{array}$ & $\begin{array}{c}-288.110^{* * *} \\
(69.179) \\
{[-4.165]}\end{array}$ & $\begin{array}{c}-288.110^{* * *} \\
(70.129) \\
{[-4.108]}\end{array}$ \\
\hline Time Fixed Effects & Year & State*Year & Year & State*Year & Year & State*Year \\
\hline State*FP \& Year*FP & No & No & No & No & No & No \\
\hline Observations & 23482 & 23482 & 11044 & 11044 & 10954 & 10954 \\
\hline R-squared & 0.180 & 0.190 & 0.232 & 0.235 & 0.132 & 0.137 \\
\hline P-value ${ }^{1}$ & 0.002 & 0.002 & 0.002 & 0.003 & 0.000 & 0.000 \\
\hline \multirow[t]{2}{*}{ Panel B: 4 year schools } & \multicolumn{2}{|c|}{$2000-2014$} & \multicolumn{2}{|c|}{$2000-2006$} & \multicolumn{2}{|c|}{$2008-2014$} \\
\hline & (1) & $(2)$ & $(3)$ & (4) & $(5)$ & $(6)$ \\
\hline$\overline{(2000 \text { For-profit Supply })^{*} \hat{\eta}}$ & $\begin{array}{c}24.566 \\
(42.704)\end{array}$ & $\begin{array}{c}37.205 \\
(41.812)\end{array}$ & $\begin{array}{c}54.694 \\
(33.517)\end{array}$ & $\begin{array}{l}60.847^{*} \\
(32.544)\end{array}$ & $\begin{array}{c}92.066^{* * *} \\
(20.323)\end{array}$ & $\begin{array}{c}93.326^{* * *} \\
(21.406)\end{array}$ \\
\hline$($ For-profit $) *(2000 \text { Supply })^{*} \hat{\eta}$ & $\begin{array}{c}-232.020^{* * *} \\
(72.057) \\
{[-3.220]}\end{array}$ & $\begin{array}{c}-232.020^{* * *} \\
(73.138) \\
{[-3.172]}\end{array}$ & $\begin{array}{c}-177.450^{* * *} \\
(50.380) \\
{[-3.522]}\end{array}$ & $\begin{array}{c}-177.450^{* * *} \\
(51.069) \\
{[-3.475]}\end{array}$ & $\begin{array}{c}-298.050^{* * *} \\
(60.617) \\
{[-4.917]}\end{array}$ & $\begin{array}{c}-298.050^{* * *} \\
(61.453) \\
{[-4.850]}\end{array}$ \\
\hline Time Fixed Eff & Year & State*Year & Year & State*Year & Year & State*Year \\
\hline State*FP \& Year*FP & Yes & Yes & Yes & Yes & Yes & Yes \\
\hline Observations & 23482 & 23482 & 11044 & 11044 & 10954 & 10954 \\
\hline R-squared & 0.230 & 0.239 & 0.285 & 0.287 & 0.204 & 0.209 \\
\hline P-value ${ }^{1}$ & 0.006 & 0.007 & 0.000 & 0.001 & 0.000 & 0.000 \\
\hline
\end{tabular}

Authors estimates of equation (4) in the text using for-profit and public institutions, excluding all institutions with a rating of "Highly Competitive" or higher in the 2001 Barron's rankings. The dependent variable is total 12-month enrollment aggregated by CBSA, sector (public or for-profit) and level (two-year or four-year). Robust standard errors adjusted for clustering by CBSA are in parentheses: ${ }^{*},{ }^{* *},{ }^{* *}$ indicate significance at the 10,5 , and 1 percent level, respectively. "P-value" shows the p-value of F-tests for joint significance of instruments. Labor demand shocks are proxied by three-year rolling predicted changes as described in the text. Two- digit industry employment data from QCEW are used for computation of labor demand shocks. The supply measure is percentage of for-profit institutions at the corresponding level (two-year or four-year) in the CBSA in 2000 or 2007 (for 2008-14 period). All regressions include the following CBSA-year level variables as controls: base-year employment, gender composition (\% female), racial composition (\% black, \%Hispanic, \%American Indian, \%Asian, \% Two or more races), age composition (\%20-29, \%30-39, \%40 or over), \%poverty and total population. All regressions also include CBSA and year fixed effects, while even columns include state-by-year fixed effects. Two year estimates include two-year and less than two year institutions and exclude the 65 CBSAs that only have a for-profit college in the base year. 
Table A-9: Instrumental Variables Estimates of the Effect of For-profit Attendance on the Number and Volume of Student Loan Originations and Defaults, Excluding Selective Institutions

\begin{tabular}{lcccc}
\hline \hline & \multicolumn{4}{c}{ Panel A: Number of Loans } \\
\cline { 2 - 5 } & \multicolumn{4}{c}{4 -year Schools } \\
\cline { 2 - 5 } & $0.449^{* * *}$ & $0.501^{* * *}$ & $0.467^{* *}$ & $0.515^{* * *}$ \\
Enroll & $(0.167)$ & $(0.124)$ & $(0.201)$ & $(0.164)$ \\
Enroll*For-profit & $1.120^{* * *}$ & $1.044^{* * *}$ & $1.214^{* * *}$ & $1.156^{* * *}$ \\
& $(0.311)$ & $(0.257)$ & $(0.339)$ & $(0.297)$ \\
\hline Time Fixed Effects & Year & Year & State*Year & State*Year \\
State*FP \& Year*FP & No & Yes & No & Yes \\
Observations & 23432 & 23432 & 23432 & 23432 \\
\hline \hline & \multicolumn{4}{c}{ Panel B: Loan Origination Amount $(\$)$} \\
\cline { 2 - 5 } & \multicolumn{4}{c}{4 -year Schools } \\
\cline { 2 - 5 } & $(1)$ & $(2)$ & $(3)$ & $(4)$ \\
\hline Enroll & $1531.30^{* * *}$ & $1906.80^{* * *}$ & $1626.80^{* * *}$ & $1979.70^{* * *}$ \\
& $(465.52)$ & $(290.02)$ & $(590.00)$ & $(338.95)$ \\
Enroll*For-profit & $3591.40^{* * *}$ & $3045.20^{* * *}$ & $4083.70^{* * *}$ & $3646.00^{* * *}$ \\
& $(1141.40)$ & $(1008.80)$ & $(1191.00)$ & $(988.24)$ \\
\hline Time Fixed Effects & Year & Year & State*Year & State*Year \\
State*FP \& Year*FP & No & Yes & No & Yes \\
Observations & 23432 & 23432 & 23432 & 23432 \\
\hline \hline & Panel C: Number of Borrowers in Default $(100 \%)$ \\
\cline { 2 - 5 } & \multicolumn{4}{c}{4 -year Schools } \\
\cline { 2 - 5 } & $(1)$ & $(2)$ & $(3)$ & $(4)$ \\
\hline Enroll & $0.065^{*}$ & $0.059^{*}$ & $0.057^{*}$ & $0.052^{*}$ \\
& $(0.037)$ & $(0.031)$ & $(0.034)$ & $(0.028)$ \\
Enroll*For-profit & $0.108^{* * *}$ & $0.116^{* * *}$ & $0.100^{* * *}$ & $0.105^{* * *}$ \\
& $(0.039)$ & $(0.042)$ & $(0.038)$ & $(0.041)$ \\
\hline Time Fixed Effects & Year & Year & State*Year & State*Year \\
State*FP \& Year*FP & No & Yes & No & Yes \\
Observations & 15326 & 15326 & 15326 & 15326 \\
\hline \hline
\end{tabular}

Authors estimates of equation (5) in the text using for-profit and public institutions, excluding all institutions with a rating of "Highly Competitive" or higher in the 2001 Barron's rankings. The enrollment measure is 12-month total enrollment. Enrollment and outcomes are aggregated by CBSA, institution-type (public or for-profit) and level (two-year or four-year). Robust standard errors adjusted for clustering by CBSA are in parentheses: ${ }^{*}, * * * *$ indicate significance at the 10, 5, and 1 percent level, respectively. All regressions include the following CBSA-year level variables as controls: base-year $(t-3)$ employment, gender composition (\%female), racial composition (\%black, \%Hispanic, \%American India, \%Asian, \% Two or more races), age composition (\%20-29, \%30-39, \%40 or over), \%poverty, and total population. All regressions also include CBSA and year fixed effects. Even columns include state-for profit and year-for profit fixed effects, while columns (3)-(4) and (7)-(8) include state-by-year fixed effects. Two year estimates include two-year and less than two year institutions and exclude the 65 CBSAs that only have a for-profit college in the base year. 
Table A-10: Instrumental Variables Estimates of the Effect of For-profit Attendance on Borrowing, by Loan Type Excluding Selective Institutions

\begin{tabular}{|c|c|c|c|c|}
\hline & \multicolumn{4}{|c|}{$\frac{\text { Panel A: Number Recipients: Direct Subsidized Loans }}{\text { 4-year Schools }}$} \\
\hline & (1) & (2) & $(3)$ & (4) \\
\hline \multirow[t]{2}{*}{$\overline{\text { Enroll }}$} & $0.352^{* *}$ & $0.340^{* *}$ & $0.363^{* *}$ & $0.347^{*}$ \\
\hline & $(0.162)$ & $(0.157)$ & $(0.183)$ & $(0.177)$ \\
\hline \multirow[t]{2}{*}{ Enroll*For-profit } & $0.608^{* *}$ & $0.625^{* *}$ & $0.664^{* *}$ & $0.684^{* *}$ \\
\hline & $(0.303)$ & $(0.294)$ & $(0.314)$ & $(0.315)$ \\
\hline Time Fixed Effects & Year & Year & State*Year & State*Year \\
\hline State*FP \& Year*FP & No & Yes & No & Yes \\
\hline \multirow[t]{3}{*}{ Observations } & 23432 & 23432 & 23432 & 23432 \\
\hline & \multicolumn{4}{|c|}{$\frac{\text { Panel B: Number Recipients: Direct Unsubsidized Loans }}{4 \text {-year Schools }}$} \\
\hline & $(1)$ & $(2)$ & $(3)$ & $(4)$ \\
\hline \multirow[t]{2}{*}{ Enroll } & $0.308^{* *}$ & $0.305^{* *}$ & $0.322^{* *}$ & $0.314^{* *}$ \\
\hline & $(0.133)$ & $(0.120)$ & $(0.155)$ & $(0.144)$ \\
\hline \multirow[t]{2}{*}{ Enroll*For-profit } & $0.536^{* *}$ & $0.541^{* *}$ & $0.606^{* *}$ & $0.616^{* *}$ \\
\hline & $(0.242)$ & $(0.236)$ & $(0.266)$ & $(0.267)$ \\
\hline Time Fixed Effects & Year & Year & State*Year & State*Year \\
\hline State*FP \& Year*FP & No & Yes & No & Yes \\
\hline \multirow[t]{4}{*}{ Observations } & 23432 & 23432 & 23432 & 23432 \\
\hline & \multirow{2}{*}{\multicolumn{4}{|c|}{$\begin{array}{c}\text { Panel C: Number Recipients: FFEL Subsidized Loans } \\
\text { 4-year Schools }\end{array}$}} \\
\hline & & & & \\
\hline & (1) & $(2)$ & (3) & (4) \\
\hline \multirow[t]{2}{*}{ Enroll } & $0.154^{* *}$ & $0.163^{* * *}$ & $0.172^{* *}$ & $0.179^{* *}$ \\
\hline & $(0.068)$ & $(0.061)$ & $(0.080)$ & $(0.070)$ \\
\hline \multirow[t]{2}{*}{ Enroll*For-profit } & $0.461^{* * *}$ & $0.450^{* * *}$ & $0.487^{* * *}$ & $0.479^{* * *}$ \\
\hline & $(0.116)$ & $(0.113)$ & $(0.130)$ & $(0.130)$ \\
\hline Time Fixed Effects & Year & Year & State*Year & State*Year \\
\hline State*FP \& Year*FP & No & Yes & No & Yes \\
\hline \multirow[t]{4}{*}{ Observations } & 17256 & 17256 & 17256 & 17256 \\
\hline & \multirow{2}{*}{\multicolumn{4}{|c|}{$\frac{\text { Panel D: Number Recipients: FFEL Unsubsidized Loans }}{\text { 4-year Schools }}$}} \\
\hline & & & & \\
\hline & (1) & $(2)$ & (3) & (4) \\
\hline \multirow[t]{2}{*}{ Enroll } & $0.099^{* *}$ & $0.111^{* *}$ & $0.113^{*}$ & $0.123^{* *}$ \\
\hline & $(0.050)$ & $(0.044)$ & $(0.058)$ & $(0.050)$ \\
\hline \multirow[t]{2}{*}{ Enroll*For-profit } & $0.419^{* * *}$ & $0.405^{* * *}$ & $0.440 * * *$ & $0.428^{* * *}$ \\
\hline & $(0.076)$ & $(0.076)$ & $(0.086)$ & $(0.087)$ \\
\hline Time Fixed Effects & Year & Year & State*Year & State*Year \\
\hline State*FP \& Year*FP & No & Yes & No & Yes \\
\hline Observations & 17256 & 17256 & 17256 & 17256 \\
\hline
\end{tabular}

Authors estimates of equation (5) in the text using for-profit and public institutions, excluding all institutions with a rating of "Highly Competitive" or higher in the 2001 Barron's rankings. The enrollment measure is 12-month total enrollment. Enrollment and outcomes are aggregated by CBSA, institution-type (public or for-profit) and level (two-year or four-year). Robust standard errors adjusted for clustering by CBSA are in parentheses: $*, * *, * * *$ indicate significance at the 10, 5, and 1 percent level, respectively. All regressions include the following CBSA-year level variables as controls: base-year $(t-3)$ employment, gender composition (\%female), racial composition (\%black, \%Hispanic, \%American India, \%Asian, \% Two or more races), age composition (\%20-29, \%30-39, \%40 or over), \%poverty, and total population. All regressions also include CBSA and year fixed effects. Even columns include state-for profit and year-for profit fixed effects, while columns (3)-(4) and (7)-(8) include state-by-year fixed effects. Two year estimates include two-year and less than two year institutions and exclude the 65 CBSAs that only have a for-profit college in the base year. 
Table A-11: Instrumental Variables Estimates of the Effect of For-profit Attendance on Graduation, Employment, and Earnings, Excluding Selective Institutions

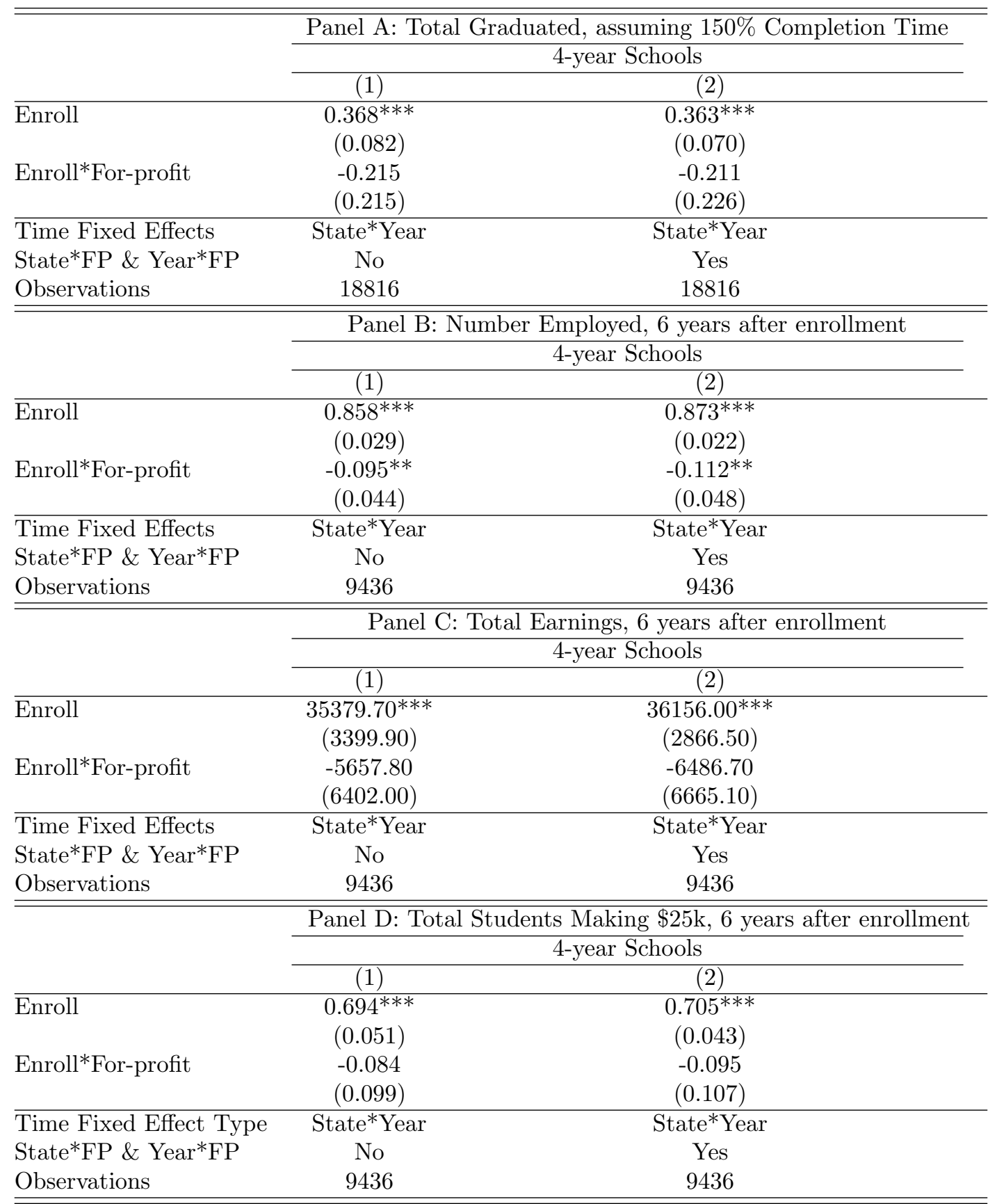

Authors estimates of equation (5) in the text using for-profit and public institutions, excluding all institutions with a rating of "Highly Competitive" or higher in the 2001 Barron's rankings. The enrollment measure is 12-month total enrollment. Enrollment and outcomes are aggregated by CBSA, institution-type (public or for-profit) and level (two-year or four-year). Robust standard errors adjusted for clustering by CBSA are in parentheses: $*, * *, * * *$ indicate significance at the 10, 5, and 1 percent level, respectively. All regressions include the following CBSA-year level variables as controls: base-year $(t-3)$ employment, gender composition (\%female), racial composition (\%black, \%Hispanic, \%American India, \%Asian, \%Two or more races), age composition (\%20-29, \%30-39, \%40 or over), \%poverty, and total population. All regressions also include CBSA and state-by-year fixed effects. Even columns include state-for profit and year-for profit fixed effects. Two year estimates include two-year and less than two year institutions and exclude the 65 CBSAs that only have a for-profit college in the base year. 
Table A-12: Instrumental Variables Estimates of the Effect of For-profit Attendance on the Number and Volume of Student Loan Originations and Defaults, Including Baseline Degree Composition X Year Controls

\begin{tabular}{|c|c|c|c|c|c|c|c|c|}
\hline & \multicolumn{8}{|c|}{ Panel A: Number of Loans } \\
\hline & \multicolumn{4}{|c|}{ 4-year Schools } & \multicolumn{4}{|c|}{ 2-year Schools } \\
\hline Enroll & $0.441^{* * *}$ & $0.468^{* * *}$ & $0.453^{* * *}$ & $0.477^{* * *}$ & 0.103 & 0.124 & 0.083 & 0.120 \\
\hline \multirow[t]{2}{*}{ Enroll*For-profit } & $1.016^{* * *}$ & $0.983^{* * *}$ & $1.078^{* * *}$ & $1.056^{* * *}$ & $1.391^{* *}$ & $1.518^{*}$ & 1.276 & 1.491 \\
\hline & $(0.265)$ & $(0.252)$ & $(0.276)$ & $(0.267)$ & $(0.674)$ & $(0.909)$ & $(1.136)$ & $(1.901)$ \\
\hline Time Fixed Effects & Year & Year & State*Year & State*Year & Year & Year & State*Year & State*Year \\
\hline \multirow{3}{*}{ Observations } & \multicolumn{8}{|c|}{ Panel B: Loan Origination Amount (\$) } \\
\hline & \multicolumn{4}{|c|}{ 4-year Schools } & \multicolumn{4}{|c|}{ 2-year Schools } \\
\hline & (1) & $(2)$ & $(3)$ & $(4)$ & $(5)$ & $(6)$ & $(7)$ & $(8)$ \\
\hline \multirow[t]{2}{*}{ Enroll } & $1438.80^{* * *}$ & $1700.70^{* * *}$ & $1502.70^{* * *}$ & $1754.20^{* * *}$ & 617.12 & 759.67 & 782.95 & 1211.30 \\
\hline & $(411.06)$ & $(381.13)$ & $(432.22)$ & $(320.68)$ & $(376.36)$ & $(480.96)$ & $(616.15)$ & $(1279.10)$ \\
\hline \multirow[t]{4}{*}{ Observations } & 23482 & 23482 & 23482 & 23482 & 21666 & 21666 & 21666 & 21666 \\
\hline & \multicolumn{8}{|c|}{ Panel C: Number of Borrowers in Default (100\%) } \\
\hline & \multicolumn{4}{|c|}{ 4-year Schools } & \multicolumn{4}{|c|}{ 2-year Schools } \\
\hline & $(1)$ & $(2)$ & $(3)$ & $(4)$ & $(5)$ & $(6)$ & $(7)$ & (8) \\
\hline \multirow[t]{2}{*}{ Enroll } & $0.066^{*}$ & $0.062^{* *}$ & $0.060^{*}$ & $0.055^{*}$ & $0.026^{*}$ & 0.044 & 0.040 & 0.201 \\
\hline & $(0.036)$ & $(0.031)$ & $(0.036)$ & $(0.030)$ & $(0.014)$ & $(0.042)$ & $(0.047)$ & $(1.275)$ \\
\hline \multirow[t]{2}{*}{ Enroll*For-profit } & $0.109 * * *$ & $0.114^{* * *}$ & $0.104^{* * *}$ & $0.106^{* * *}$ & $0.211^{* *}$ & 0.350 & 0.311 & 1.485 \\
\hline & $(0.037)$ & $(0.039)$ & $(0.039)$ & $(0.040)$ & $(0.101)$ & $(0.314)$ & $(0.338)$ & $(9.290)$ \\
\hline Time Fixed Effects & Year & Year & State*Year & State*Year & Year & Year & State*Year & State*Year \\
\hline State*FP \& Year*FP & No & Yes & No & Yes & No & Yes & No & Yes \\
\hline Observations & 15347 & 15347 & 15347 & 15347 & 14500 & 14500 & 14500 & 14500 \\
\hline
\end{tabular}

Authors estimates of equation (5) in the text using for-profit and public institutions. The enrollment measure is 12-month total enrollment. Enrollment and outcomes are aggregated by CBSA, institution-type (public or for-profit) and level (two-year or four-year). Robust standard errors adjusted for clustering by CBSA are in parentheses: *,**,*** indicate significance at the 10, 5 , and 1 percent level, respectively. All regressions include the following CBSA-year level variables as controls: base-year $(t-3)$ employment, gender composition (\%female), racial composition (\%black, \%Hispanic, \%American India, \%Asian, \% Two or more races), age composition (\%20-29, \%30-39, \%40 or over), \%poverty, and total population. All regressions also include CBSA and year fixed effects. Even columns include state-for profit and year-for profit fixed effects, while columns (3)-(4) and (7)-(8) include state-by-year fixed effects. All 2-year estimates include \%Certificates Degrees awarded in the baseline year interacted with year dummies, while all 4-year estimates include \%Bachelors Degrees awarded in the baseline year interacted with year dummies. Two year estimates include two-year and less than two year institutions and exclude the 65 CBSAs that only have a for-profit college in the base year. 
Table A-13: Instrumental Variables Estimates of the Effect of For-profit Attendance on Student Borrowing, by Loan Type Including Baseline Degree Composition X Year Controls

\begin{tabular}{|c|c|c|c|c|c|c|c|c|}
\hline & \multicolumn{8}{|c|}{ Panel A: Number Recipients: Direct Subsidized Loans } \\
\hline & \multicolumn{4}{|c|}{ 4-year Schools } & \multicolumn{4}{|c|}{ 2-year Schools } \\
\hline & (1) & $(2)$ & $(3)$ & (4) & $(5)$ & (6) & (7) & (8) \\
\hline \multirow[t]{2}{*}{ Enroll } & $0.343^{* *}$ & $0.329^{* *}$ & $0.353^{* *}$ & $0.338^{*}$ & 0.011 & 0.006 & -0.024 & -0.056 \\
\hline & $(0.154)$ & $(0.158)$ & $(0.177)$ & $(0.182)$ & $(0.121)$ & $(0.155)$ & $(0.209)$ & $(0.371)$ \\
\hline \multirow[t]{2}{*}{ Enroll*For-profit } & $0.613^{* *}$ & $0.634^{* *}$ & $0.673^{* *}$ & $0.696^{* *}$ & 0.183 & 0.139 & -0.025 & -0.258 \\
\hline & $(0.276)$ & $(0.275)$ & $(0.282)$ & $(0.290)$ & $(0.714)$ & $(0.995)$ & $(1.244)$ & $(2.409)$ \\
\hline Time Fixed Effects & Year & Year & State*Year & State*Year & Year & Year & State*Year & State*Year $^{*}$ \\
\hline State*FP \& Year*FP & No & Yes & No & Yes & No & Yes & No & Yes \\
\hline \multirow[t]{4}{*}{ Observations } & 23482 & 23482 & 23482 & 23482 & 21666 & 21666 & 21666 & 21666 \\
\hline & \multicolumn{8}{|c|}{ Panel B: Number Recipients: Direct Unsubsidized Loans } \\
\hline & \multicolumn{4}{|c|}{ 4-year Schools } & \multicolumn{4}{|c|}{ 2-year Schools } \\
\hline & (1) & $(2)$ & $(3)$ & (4) & $(5)$ & $(6)$ & (7) & $(8)$ \\
\hline \multirow[t]{2}{*}{ Enroll } & $0.297^{* *}$ & $0.290^{* *}$ & $0.310^{* *}$ & $0.301^{* *}$ & 0.020 & 0.020 & -0.013 & -0.031 \\
\hline & $(0.122)$ & $(0.116)$ & $(0.144)$ & $(0.141)$ & $(0.106)$ & $(0.134)$ & $(0.184)$ & $(0.316)$ \\
\hline \multirow[t]{2}{*}{ Enroll*For-profit } & $0.519^{* *}$ & $0.532^{* *}$ & $0.590^{* *}$ & $0.608^{* *}$ & 0.241 & 0.233 & 0.048 & -0.096 \\
\hline & $(0.215)$ & $(0.220)$ & $(0.234)$ & $(0.244)$ & $(0.623)$ & $(0.853)$ & $(1.093)$ & $(2.047)$ \\
\hline Time $\mathrm{H}$ & Year & Year & State*Year & State*Year & Year & Year & State*Year & State*Year \\
\hline State*FP \& Y & No & Yes & No & Yes & No & Yes & No & Yes \\
\hline \multirow[t]{4}{*}{ Observations } & 23482 & 23482 & 23482 & 23482 & 21666 & 21666 & 21666 & 21666 \\
\hline & \multicolumn{8}{|c|}{ 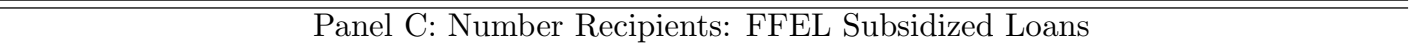 } \\
\hline & \multicolumn{4}{|c|}{ 4-year Schools } & \multicolumn{4}{|c|}{ 2-year Schools } \\
\hline & $(1)$ & $(2)$ & $(3)$ & $(4)$ & $(5)$ & $(6)$ & (7) & $(8)$ \\
\hline \multirow[t]{2}{*}{ Enroll } & $0.155^{* *}$ & $0.165^{* *}$ & $0.174^{* *}$ & $0.184^{* *}$ & -0.012 & -0.012 & -0.065 & -0.105 \\
\hline & $(0.069)$ & $(0.065)$ & $(0.084)$ & $(0.078)$ & $(0.031)$ & $(0.044)$ & $(0.070)$ & $(0.163)$ \\
\hline \multirow[t]{2}{*}{ Enroll*For-profit } & $0.457^{* * *}$ & $0.444^{* * *}$ & $0.485^{* * *}$ & $0.476^{* * *}$ & 0.115 & 0.103 & -0.237 & -0.541 \\
\hline & $(0.117)$ & $(0.111)$ & $(0.135)$ & $(0.132)$ & $(0.196)$ & $(0.287)$ & $(0.458)$ & $(1.134)$ \\
\hline Time Fixed Effects & Year & Year & State*Year & State*Year & Year & Year & State*Year & State*Year \\
\hline State & No & Yes & No & Yes & No & Yes & No & Yes \\
\hline \multirow[t]{4}{*}{ Observations } & 17290 & 17290 & 17290 & 17290 & 15946 & 15946 & 15946 & 15946 \\
\hline & \multicolumn{8}{|c|}{$\begin{array}{l}\text { Panel D: Number Recipients: FFEL Unsubsidized Loans } \\
\end{array}$} \\
\hline & \multicolumn{4}{|c|}{ 4-year Schools } & \multicolumn{4}{|c|}{ 2-year Schools } \\
\hline & (1) & $(2)$ & (3) & (4) & $(5)$ & $(6)$ & (7) & (8) \\
\hline Enroll & $\begin{array}{c}0.095^{*} \\
(0.050)\end{array}$ & $\begin{array}{c}0.106^{* *} \\
(0.046)\end{array}$ & $0.109^{*}$ & $0.120^{* *}$ & 0.007 & 0.015 & -0.023 & $\begin{array}{c}-0.032 \\
(0.0855)\end{array}$ \\
\hline \multirow[t]{2}{*}{ Enroll*For-profit } & $0.414^{* * *}$ & $0.401^{* * *}$ & $0.435^{* * *}$ & $0.425^{* * *}$ & 0.241 & 0.275 & 0.041 & -0.045 \\
\hline & $(0.074)$ & $(0.072)$ & $(0.085)$ & $(0.085)$ & $(0.149)$ & $(0.225)$ & $(0.280)$ & $(0.575)$ \\
\hline Time Fixed Effects & Year & Year & State*Year & State*Year & Year & Year & State*Year & State*Year \\
\hline State*FP \& Year*FP & No & Yes & No & Yes & No & Yes & No & Yes \\
\hline Observations & 17290 & 17290 & 17290 & 17290 & 15946 & 15946 & 15946 & 15946 \\
\hline
\end{tabular}

Authors estimates of equation (5) in the text using for-profit and public institutions. The enrollment measure is 12-month total enrollment. Enrollment and outcomes are aggregated by CBSA, institution-type (public or for-profit) and level (two-year or four-year). Robust standard errors adjusted for clustering by CBSA are in parentheses: *,**,*** indicate significance at the 10, 5, and 1 percent level, respectively. All regressions include the following CBSA-year level variables as controls: base-year $(t-3)$ employment, gender composition (\%female), racial composition (\%black, \%Hispanic, \%American India, \%Asian, \%Two or more races), age composition (\%20-29, \%30-39, \%40 or over), \%poverty, and total population. All regressions also include CBSA and year fixed effects. Even columns include state-for profit and year-for profit fixed effects, while columns (3)-(4) and (7)-(8) include state-by-year fixed effects. All 2-year estimates include \%Certificates Degrees awarded in the baseline year interacted with year dummies, while all 4-year estimates include \%Bachelors Degrees awarded in the baseline year interacted with year dummies. Two year estimates include two-year and less than two year institutions and exclude the 65 CBSAs that only have a for-profit college in the base year. 
Table A-14: Instrumental Variables Estimates of the Effect of For-profit Attendance on Employment, Earnings, and Graduation, Including Baseline Degree Composition X Year Controls

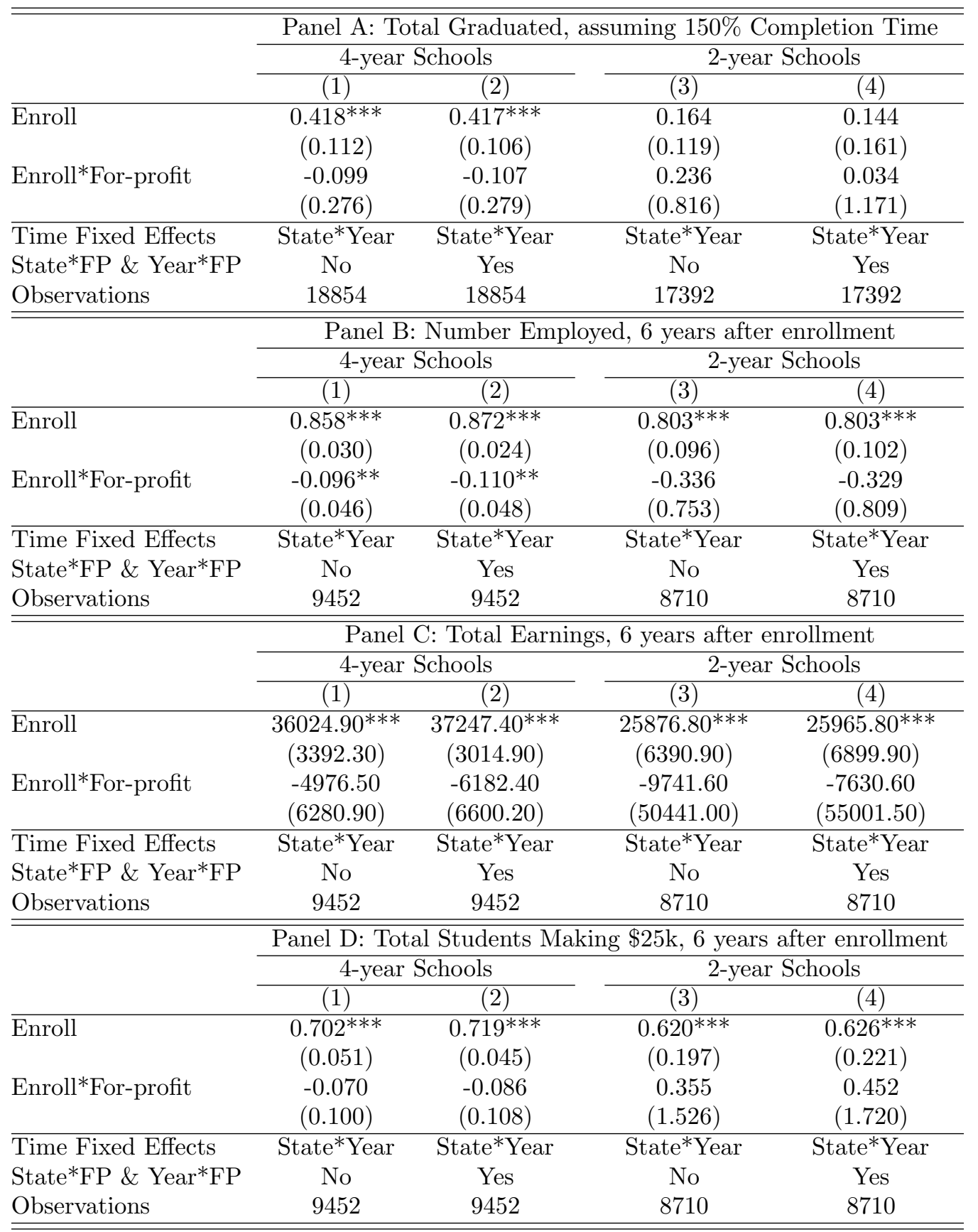

Authors estimates of equation (5) in the text using for-profit and public institutions. The enrollment measure is 12-month total enrollment. Enrollment and outcomes are aggregated by CBSA, institution-type (public or for-profit) and level (two-year or four-year). Robust standard errors adjusted for clustering by CBSA are in parentheses: $*, * *, * * *$ indicate significance at the 10,5 , and 1 percent level, respectively. All regressions include the following CBSA-year level variables as controls: base-year $(t-3)$ employment, gender composition (\%female), racial composition (\%black, \%Hispanic, \%American India, \%Asian, \% Two or more races), age composition (\%20-29, \%30-39, \%40 or over), \%poverty, and total population. All regressions also include CBSA and state-by-year fixed effects. Even columns include state-for profit and year-for profit fixed effects. All 2-year estimates include \%Certificates Degrees awarded in the baseline year interacted with year dummies, while all 4-year estimates include \%Bachelors Degrees awarded in the baseline year interacted with year dummies. Two year estimates include two-year and less than two year institutions and exclude the 65 CBSAs that only have a for-profit college in the base year. 
Table A-15: Instrumental Variables Analysis Estimates of the Impact of For-profit Attendance on Outcomes by Percent of Bachelors Degrees Awarded

\begin{tabular}{|c|c|c|c|c|c|c|c|c|}
\hline & \multicolumn{8}{|c|}{ Panel A: Number of Loans } \\
\hline & \multicolumn{4}{|c|}{$25-50 \%$ Bachelors Degrees } & \multicolumn{4}{|c|}{$75 \%$ or more Bachelors Degrees } \\
\hline & $(1)$ & $(2)$ & $(3)$ & $(4)$ & $(5)$ & $(6)$ & $(7)$ & $(8)$ \\
\hline \multirow[t]{2}{*}{$\overline{\overline{\text { Enroll }}}$} & 0.413 & 0.489 & 0.399 & 0.477 & $0.418^{* * *}$ & $0.487^{* * *}$ & $0.432^{* * *}$ & $0.504^{* * *}$ \\
\hline & $(0.683)$ & $(0.518)$ & $(0.688)$ & $(0.522)$ & $(0.138)$ & $(0.106)$ & $(0.142)$ & $(0.108)$ \\
\hline \multirow[t]{2}{*}{ Enroll*For-profit } & $1.290^{* *}$ & $1.216^{* * *}$ & $1.315^{* *}$ & $1.238^{* * *}$ & $0.781^{* *}$ & $0.725^{* *}$ & $0.889^{* * *}$ & $0.825^{* * *}$ \\
\hline & $(0.603)$ & $(0.436)$ & $(0.610)$ & $(0.444)$ & $(0.368)$ & $(0.357)$ & $(0.295)$ & $(0.269)$ \\
\hline Time Fixed Effects & Year & Year & State*Year & State*Year & Year & Year & State*Year & State*Year \\
\hline State*FP \& Year*FP & No & Yes & No & Yes & No & Yes & No & Yes \\
\hline \multirow[t]{4}{*}{ Observations } & 20642 & 20642 & 20642 & 20642 & 15418 & 15418 & 15418 & 15418 \\
\hline & \multicolumn{8}{|c|}{ Panel B: Loan Origination Amount (\$) } \\
\hline & \multicolumn{4}{|c|}{$25-50 \%$ Bachelors Degrees } & \multicolumn{4}{|c|}{$75 \%$ or more Bachelors Degrees } \\
\hline & (1) & $(2)$ & $(3)$ & $(4)$ & $(5)$ & $(6)$ & (7) & $(8)$ \\
\hline \multirow[t]{2}{*}{$\overline{\overline{\text { Enroll }}}$} & 3867.20 & 3639.40 & 3797.20 & 3581.60 & 969.65 & 1132.20 & $1166.80^{* *}$ & $1381.60^{* *}$ \\
\hline & $(3145.50)$ & $(2417.70)$ & $(3115.20)$ & $(2392.50)$ & $(913.79)$ & $(1175.60)$ & $(570.19)$ & $(614.38)$ \\
\hline \multirow[t]{2}{*}{ Enroll*For-profit } & 2247.30 & 2469.20 & 2368.50 & 2578.70 & -416.79 & -550.02 & 1115.80 & 925.24 \\
\hline & $(2733.30)$ & $(2035.70)$ & $(2712.90)$ & $(2018.60)$ & $(5591.30)$ & $(5239.70)$ & $(2596.50)$ & $(2400.20)$ \\
\hline Time Fixed Effects & Year & Year & State*Year & State*Year & Year & Year & State*Year & State*Year \\
\hline State*FP \& Year*FP & No & Yes & No & Yes & No & Yes & No & Yes \\
\hline \multirow[t]{4}{*}{ Observations } & 20642 & 20642 & 20642 & 20642 & 15418 & 15418 & 15418 & 15418 \\
\hline & \multicolumn{8}{|c|}{ Panel C: Number of Borrowers in Default (100\%) } \\
\hline & \multicolumn{4}{|c|}{$25-50 \%$ Bachelors Degrees } & \multicolumn{4}{|c|}{$75 \%$ or more Bachelors Degrees } \\
\hline & $(1)$ & $(2)$ & $(3)$ & $(4)$ & $(5)$ & $(6)$ & $(7)$ & $(8)$ \\
\hline \multirow[t]{2}{*}{$\overline{\overline{\text { Enroll }}}$} & 0.065 & 0.049 & 0.066 & 0.048 & 0.044 & 0.042 & 0.034 & 0.032 \\
\hline & $(0.195)$ & $(0.144)$ & $(0.187)$ & $(0.138)$ & $(0.058)$ & $(0.047)$ & $(0.035)$ & $(0.030)$ \\
\hline \multirow[t]{2}{*}{ Enroll*For-profit } & 0.063 & 0.077 & 0.057 & 0.070 & 0.145 & 0.129 & 0.118 & 0.108 \\
\hline & $(0.118)$ & $(0.078)$ & $(0.112)$ & $(0.074)$ & $(0.133)$ & $(0.103)$ & $(0.076)$ & $(0.066)$ \\
\hline Time Fixed Effects & Year & Year & State*Year & State*Year & Year & Year & State*Year & State*Year $^{*}$ \\
\hline State*FP \& Year*FP & No & Yes & No & Yes & No & Yes & No & Yes \\
\hline \multirow[t]{4}{*}{ Observations } & 13856 & 13856 & 13856 & 13856 & 9654 & 9654 & 9654 & 9654 \\
\hline & \multicolumn{8}{|c|}{ Panel D: Number Employed, 6 years after enrollment } \\
\hline & \multicolumn{4}{|c|}{$25-50 \%$ Bachelors Degrees } & \multicolumn{4}{|c|}{$75 \%$ or more Bachelors Degrees } \\
\hline & $(1)$ & $(2)$ & $(3)$ & $(4)$ & $(5)$ & $(6)$ & $(7)$ & $(8)$ \\
\hline \multirow[t]{2}{*}{$\overline{\overline{\text { Enroll }}}$} & $1.054^{* * *}$ & $1.022^{* * *}$ & $1.060^{* * *}$ & $1.024^{* * *}$ & $0.843^{* * *}$ & $0.852^{* * *}$ & $0.837^{* * *}$ & $0.846^{* * *}$ \\
\hline & $(0.234)$ & $(0.157)$ & $(0.226)$ & $(0.151)$ & $(0.039)$ & $(0.033)$ & $(0.045)$ & $(0.037)$ \\
\hline \multirow[t]{2}{*}{ Enroll*For-profit } & -0.149 & -0.119 & -0.171 & -0.138 & -0.184 & $-0.196^{*}$ & -0.203 & $-0.215^{*}$ \\
\hline & $(0.331)$ & $(0.257)$ & $(0.295)$ & $(0.223)$ & $(0.113)$ & $(0.103)$ & $(0.126)$ & $(0.118)$ \\
\hline Time Fixed Effects & Year & Year & State*Year & State*Year & Year & Year & State*Year & State*Year \\
\hline State*FP \& Year*FP & No & Yes & No & Yes & No & Yes & No & Yes \\
\hline Observations & 8382 & 8382 & 8382 & 8382 & 6182 & 6182 & 6182 & 6182 \\
\hline
\end{tabular}

This table uses public and for-profit institutions. The enrollment measure is 12-month total enrollment. Enrollment and outcomes are aggregated to geography (here CBSA), institution-type (public or for-profit) and level (two-year or four-year). *,**,***: significant at the 10,5, and 1 percent level, respectively. Robust standard errors adjusted for clustering by CBSA are in parentheses. Labor demand shocks are proxied by three-year or one-year rolling Bartik shocks. Results for one-year Bartik shocks are not presented in tables, but are qualitavely similar. Two-digit industry employment data from QCEW are used for computation of Bartik shocks. The supply measure is For-profit Attendance at the corresponding level (two-year or four-year) in the specific geography at the start of the sample period in 1999-2000. All regressions include the following CBSA level variables as controls: base-year employment, gender composition (\%female), racial composition (\%black, \%Hispanic, \%American India, \%Asian, \% Two or more races), age composition (\%20-29, \%30-39, \%40 or over), \%poverty, and total population. All regressions also include geography and year or state-year fixed effects. 
Table A-16: Instrumental Variables Estimates of the Effect of For-profit Attendance on Outcomes, Including Opposite-Level Supply

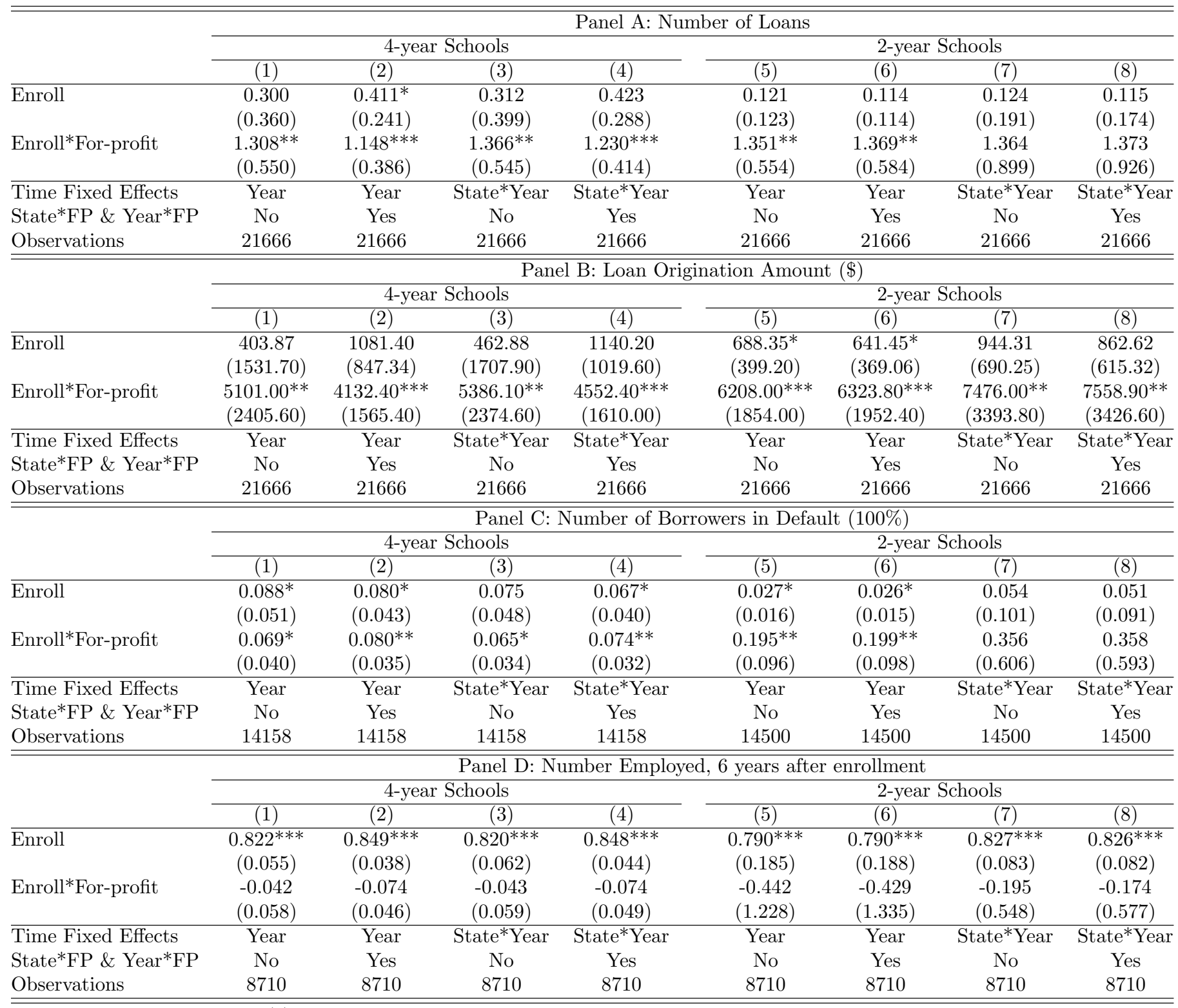

Authors estimates of equation (5) in the text using for-profit and public institutions. The enrollment measure is 12-month total enrollment. Enrollment and outcomes are aggregated by CBSA, institution-type (public or for-profit) and level (two-year or four-year). Robust standard errors adjusted for clustering by CBSA are in parentheses: *,**,*** indicate significance at the 10, 5, and 1 percent level, respectively. All regressions include the following CBSA-year level variables as controls: base-year $(t-3)$ employment, gender composition (\%female), racial composition (\%black, \%Hispanic, \%American India, \%Asian, \% Two or more races), age composition (\%20-29, \%30-39, \%40 or over), \%poverty, and total population. All regressions also include CBSA and year fixed effects. Even columns include state-for profit and year-for profit fixed effects, while columns (3)-(4) and (7)-(8) include state-by-year fixed effects. Four-year estimates include controls for two-year for-profit supply fully interacted with $F P$ and $\hat{\eta}$, while two-year estimates control for four-year for-profit supply fully interacted with $F P$ and $\hat{\eta}$. Two year estimates include two-year and less than two year institutions and exclude the 65 CBSAs that only have a for-profit college in the base year. 
Table A-17: Instrumental Variables Estimates of the Effect of For-profit Attendance on Outcomes, Replacing Total Population with College-age Population + College-age Population $^{2}$

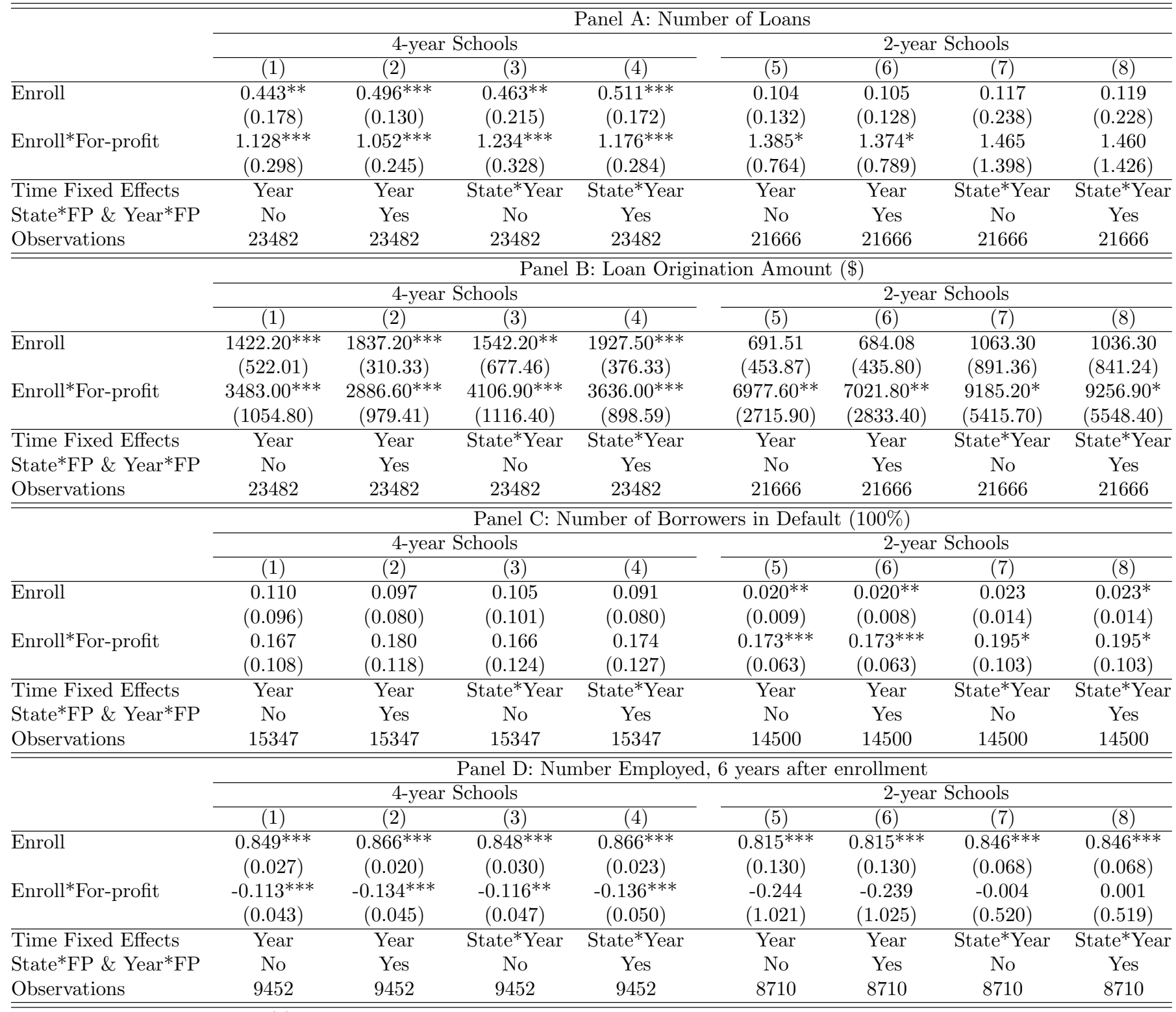

Authors estimates of equation (5) in the text using for-profit and public institutions. The enrollment measure is 12-month total enrollment. Enrollment and outcomes are aggregated by CBSA, institution-type (public or for-profit) and level (two-year or four-year). Robust standard errors adjusted for clustering by CBSA are in parentheses: $*, * *, * * *$ indicate significance at the 10, 5 , and 1 percent level, respectively. All regressions include the following CBSA-year level variables as controls: base-year $(t-3)$ employment, gender composition (\%female), racial composition (\%black, \%Hispanic, \%American India, \%Asian, \%Two or more races), age composition (\%20-29, \%30-39, \%40 or over), \%poverty, college-age population, and college-age population squared. All regressions also include CBSA and year fixed effects. Even columns include state-for profit and year-for profit fixed effects, while columns (3)-(4) and (7)-(8) include state-by-year fixed effects. Two year estimates include two-year and less than two year institutions and exclude the 65 CBSAs that only have a for-profit college in the base year. 
Table A-18: Instrumental Variables Estimates of the Effect of For-profit Attendance on Outcomes, Fixing Institution Types in the Base Year

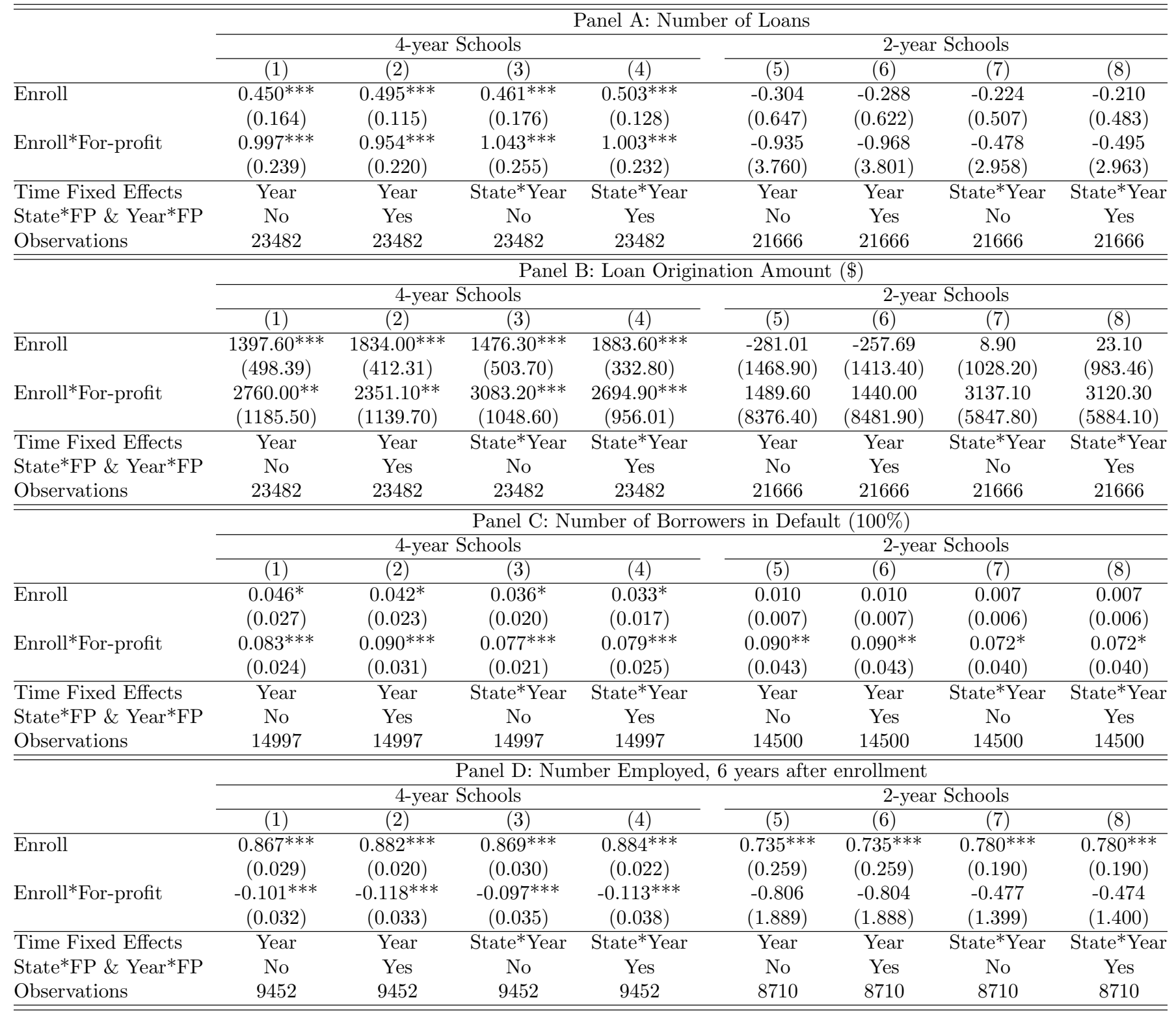

Authors estimates of equation (5) in the text using for-profit and public institutions, classifying the $5 \%$ of schools that switch from two-year to four-year during the period of our analysis as two-year schools. The enrollment measure is 12-month total enrollment. Enrollment and outcomes are aggregated by CBSA, institution-type (public or for-profit) and level (two-year or four-year). Robust standard errors adjusted for clustering by CBSA are in parentheses: $*, * *, * * *$ indicate significance at the 10,5 , and 1 percent level, respectively. All regressions include the following CBSA-year level variables as controls: base-year $(t-3)$ employment, gender composition (\%female), racial composition (\%black, \%Hispanic, \%American India, \%Asian, \% Two or more races), age composition (\%20-29, \%30-39, \%40 or over), \%poverty, and total population. All regressions also include CBSA and year fixed effects. Even columns include state-for profit and year-for profit fixed effects, while columns (3)-(4) and (7)-(8) include state-by-year fixed effects. Two year estimates include two-year and less than two year institutions and exclude the 65 CBSAs that only have a for-profit college in the base year. 
Table A-19: Instrumental Variables Estimates of the Impact of For-profit Attendance on Outcomes, Excluding Online Institutions

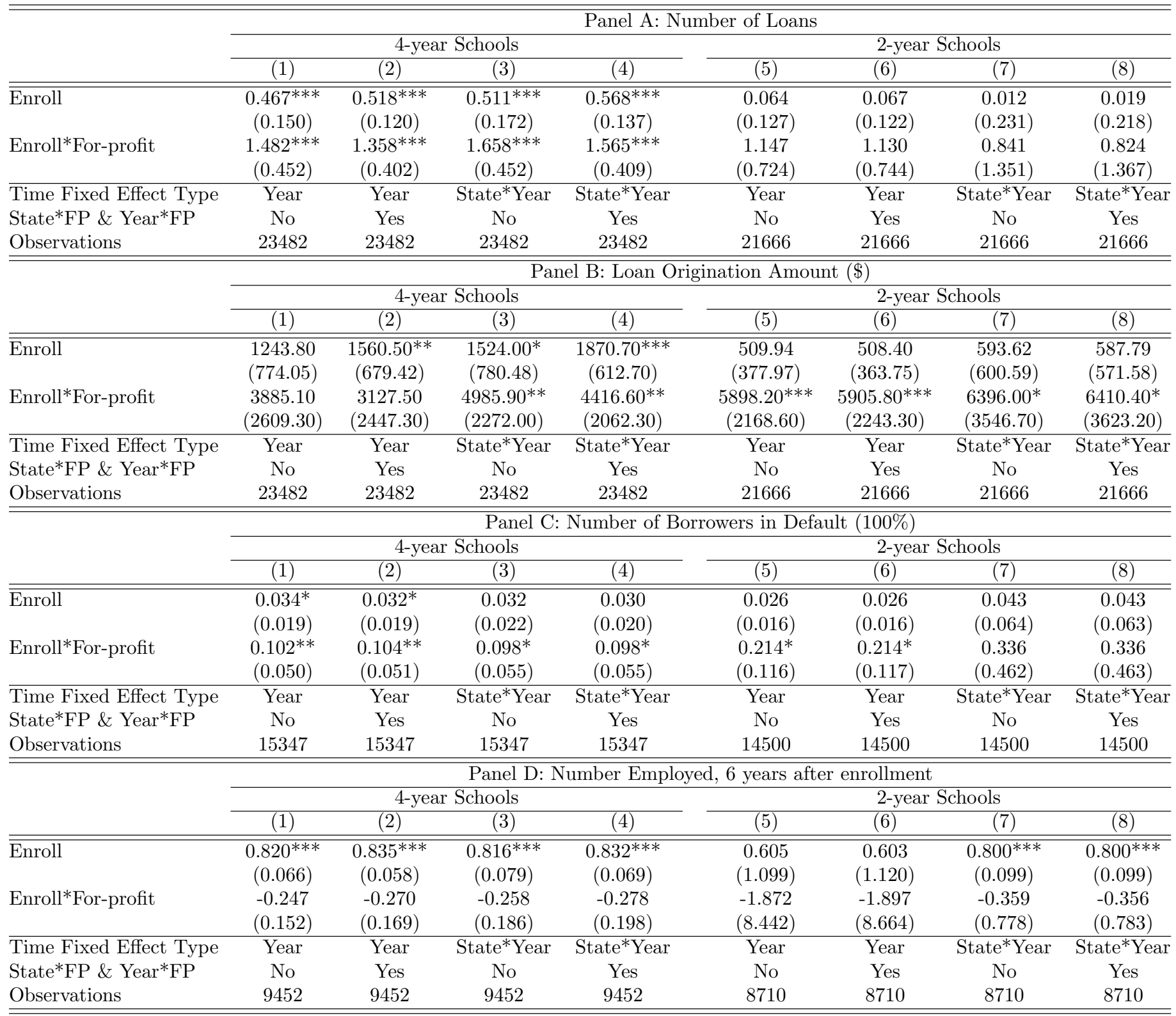

Authors estimates of equation (5) in the text using for-profit and public institutions, excluding institutions classified as online at the start of the sample period in 1999-2000. Online institutions as defined in the 2011-2014 IPEDS are excluded from the estimating sample. The enrollment measure is 12-month total enrollment. Enrollment and outcomes are aggregated by CBSA, institution-type (public or for-profit) and level (two-year or four-year). Robust standard errors adjusted for clustering by CBSA are in parentheses: $* * *, * * *$ indicate significance at the 10,5, and 1 percent level, respectively. All regressions include the following CBSA-year level variables as controls: base-year $(t-3)$ employment, gender composition (\%female), racial composition (\%black, \%Hispanic, \%American India, \%Asian, \% Two or more races), age composition (\%20-29, \%30-39, \%40 or over), \%poverty, and total population. All regressions also include CBSA and year fixed effects. Even columns include state-for profit and year-for profit fixed effects, while columns (3)-(4) and (7)-(8) include state-by-year fixed effects. Two year estimates include two-year and less than two year institutions and exclude the 65 CBSAs that only have a for-profit college in the base year. 
Table A-20: Instrumental Variables Estimates of the Impact of For-profit Attendance on Outcomes Excluding Post-2006 Cohorts

\begin{tabular}{|c|c|c|c|c|c|c|c|c|}
\hline & \multicolumn{8}{|c|}{ Panel A: Number of Loans } \\
\hline & \multicolumn{4}{|c|}{ Year $<2006$} & \multicolumn{4}{|c|}{ Year $\leq 2006$} \\
\hline & $(1)$ & $(2)$ & $(3)$ & $(4)$ & $(5)$ & $(6)$ & $(7)$ & $(8)$ \\
\hline \multirow[t]{2}{*}{ Enroll } & $0.513^{* * *}$ & $0.527^{* * *}$ & $0.546^{* * *}$ & $0.555^{* * *}$ & $0.467^{* * *}$ & $0.494^{* * *}$ & $0.495^{* * *}$ & $0.518^{* * *}$ \\
\hline & $(0.133)$ & $(0.124)$ & $(0.165)$ & $(0.146)$ & $(0.137)$ & $(0.127)$ & $(0.157)$ & $(0.139)$ \\
\hline \multirow[t]{2}{*}{ Enroll*For-profit } & $1.132^{* * *}$ & $1.116^{* * *}$ & $1.206^{* * *}$ & $1.197^{* * *}$ & $1.069^{* * *}$ & $1.039 * * *$ & $1.125^{* * *}$ & $1.101^{* * *}$ \\
\hline & $(0.399)$ & $(0.386)$ & $(0.459)$ & $(0.455)$ & $(0.363)$ & $(0.353)$ & $(0.386)$ & $(0.381)$ \\
\hline Time Fixed Effect Type & Year & Year & State*Year & State*Year & Year & Year & State*Year & State*Year \\
\hline State*FP \& Year*FP & No & Yes & No & Yes & No & Yes & No & Yes \\
\hline \multirow[t]{4}{*}{ Observations } & 11044 & 11044 & 11044 & 11044 & 12606 & 12606 & 12606 & 12606 \\
\hline & \multicolumn{8}{|c|}{ Panel B: Loan Origination Amount (\$) } \\
\hline & \multicolumn{4}{|c|}{ Year $<2006$} & \multicolumn{4}{|c|}{ Year $\leq 2006$} \\
\hline & $(1)$ & $(2)$ & $(3)$ & $(4)$ & $(5)$ & $(6)$ & $(7)$ & $(8)$ \\
\hline$\overline{\text { Enroll }}$ & $\begin{array}{c}2179.70^{* * *} \\
(593.38)\end{array}$ & $\begin{array}{c}2231.90^{* * *} \\
(509.36)\end{array}$ & $\begin{array}{c}2359.00^{* * *} \\
(737.96)\end{array}$ & $\begin{array}{c}2383.80^{* * *} \\
(624.75)\end{array}$ & $\begin{array}{c}1952.50^{* * *} \\
(585.25)\end{array}$ & $\begin{array}{c}2075.80^{* * *} \\
(495.90)\end{array}$ & $\begin{array}{c}2098.80^{* * *} \\
(684.12)\end{array}$ & $\begin{array}{c}2201.60^{* * *} \\
(567.20)\end{array}$ \\
\hline \multirow[t]{2}{*}{ Enroll*For-profit } & $5151.90 * * *$ & $5091.60^{* * *}$ & $5556.60^{* * *}$ & $5529.80^{* * *}$ & $4753.10^{* * *}$ & $4618.70^{* * *}$ & $5040.20 * * *$ & $4934.20^{* * *}$ \\
\hline & $(1657.00)$ & $(1597.30)$ & $(1993.00)$ & $(1969.40)$ & $(1453.10)$ & $(1403.00)$ & $(1612.30)$ & $(1582.20)$ \\
\hline Time Fixed Effect Type & Year & Year & State*Year & State*Year & Year & Year & State*Year & State*Year \\
\hline State*FP \& Year*FP & No & Yes & No & Yes & No & Yes & No & Yes \\
\hline \multirow[t]{4}{*}{ Observations } & 11044 & 11044 & 11044 & 11044 & 12606 & 12606 & 12606 & 12606 \\
\hline & \multicolumn{8}{|c|}{ Panel C: Number of Borrowers in Default (100\%) } \\
\hline & \multicolumn{4}{|c|}{ Year $<2006$} & \multicolumn{4}{|c|}{ Year $\leq 2006$} \\
\hline & $(1)$ & $(2)$ & $(3)$ & $(4)$ & $(5)$ & $(6)$ & $(7)$ & $(8)$ \\
\hline \multirow[t]{2}{*}{ Enroll } & $0.023^{* * *}$ & $0.021^{* * *}$ & $0.023^{* * *}$ & $0.022^{* * *}$ & $0.017^{* * *}$ & $0.017^{* * *}$ & $0.017^{* *}$ & $0.016^{* * *}$ \\
\hline & $(0.007)$ & $(0.006)$ & $(0.007)$ & $(0.006)$ & $(0.007)$ & $(0.006)$ & $(0.007)$ & $(0.006)$ \\
\hline \multirow[t]{2}{*}{ Enroll*For-profit } & $0.088^{* * *}$ & $0.089 * * *$ & $0.088^{* * *}$ & $0.090^{* * *}$ & $0.077^{* * *}$ & $0.078^{* * *}$ & $0.076^{* * *}$ & $0.076^{* * *}$ \\
\hline & $(0.012)$ & $(0.013)$ & $(0.012)$ & $(0.013)$ & $(0.011)$ & $(0.012)$ & $(0.011)$ & $(0.012)$ \\
\hline Time Fixed Effect Type & Year & Year & State*Year & State*Year & Year & Year & State*Year & State*Year \\
\hline State*FP \& Year*FP & No & Yes & No & Yes & No & Yes & No & Yes \\
\hline \multirow[t]{4}{*}{ Observations } & 11044 & 11044 & 11044 & 11044 & 12606 & 12606 & 12606 & 12606 \\
\hline & \multicolumn{8}{|c|}{ Panel D: Number Employed, 6 years after enrollment } \\
\hline & \multicolumn{4}{|c|}{ Year $<2006$} & \multicolumn{4}{|c|}{ Year $\leq 2006$} \\
\hline & $(1)$ & $(2)$ & $(3)$ & $(4)$ & $(5)$ & $(6)$ & $(7)$ & $(8)$ \\
\hline \multirow[t]{2}{*}{ Enroll } & $0.859^{* * *}$ & $0.875^{* * *}$ & $0.859^{* * *}$ & $0.875^{* * *}$ & $0.859^{* * *}$ & $0.875^{* * *}$ & $0.859^{* * *}$ & $0.875^{* * *}$ \\
\hline & $(0.027)$ & $(0.020)$ & $(0.029)$ & $(0.022)$ & $(0.027)$ & $(0.020)$ & $(0.029)$ & $(0.022)$ \\
\hline \multirow[t]{2}{*}{ Enroll*For-profit } & $-0.093^{* *}$ & $-0.112^{* *}$ & $-0.093^{* *}$ & $-0.110^{* *}$ & $-0.093^{* *}$ & $-0.112^{* *}$ & $-0.093^{* *}$ & $-0.110^{* *}$ \\
\hline & $(0.042)$ & $(0.047)$ & $(0.044)$ & $(0.048)$ & $(0.042)$ & $(0.047)$ & $(0.044)$ & $(0.048)$ \\
\hline Time Fixed Effect Type & Year & Year & State*Year & State*Year & Year & Year & State*Year & State*Year \\
\hline State*FP \& Year*FP & No & Yes & No & Yes & No & Yes & No & Yes \\
\hline Observations & 9452 & 9452 & 9452 & 9452 & 9452 & 9452 & 9452 & 9452 \\
\hline
\end{tabular}

Authors estimates of equation (5) in the text using for-profit and public institutions and cohorts that enrolled after 2006. The enrollment measure is 12-month total enrollment. Enrollment and outcomes are aggregated by CBSA, institution-type (public or for-profit). Robust standard errors adjusted for clustering by CBSA are in parentheses: $*, * *, * * *$ indicate significance at the 10,5 , and 1 percent level, respectively. All regressions include the following CBSA-year level variables as controls: base-year $(t-3)$ employment, gender composition (\%female), racial composition (\%black, \%Hispanic, \%American India, \%Asian, \%Two or more races), age composition (\%20-29, \%30-39, \%40 or over), \%poverty, and total population. All regressions also include CBSA and year fixed effects. Even columns include state-for profit and year-for profit fixed effects, while columns (3)-(4) and (7)-(8) include state-by-year fixed effects. 


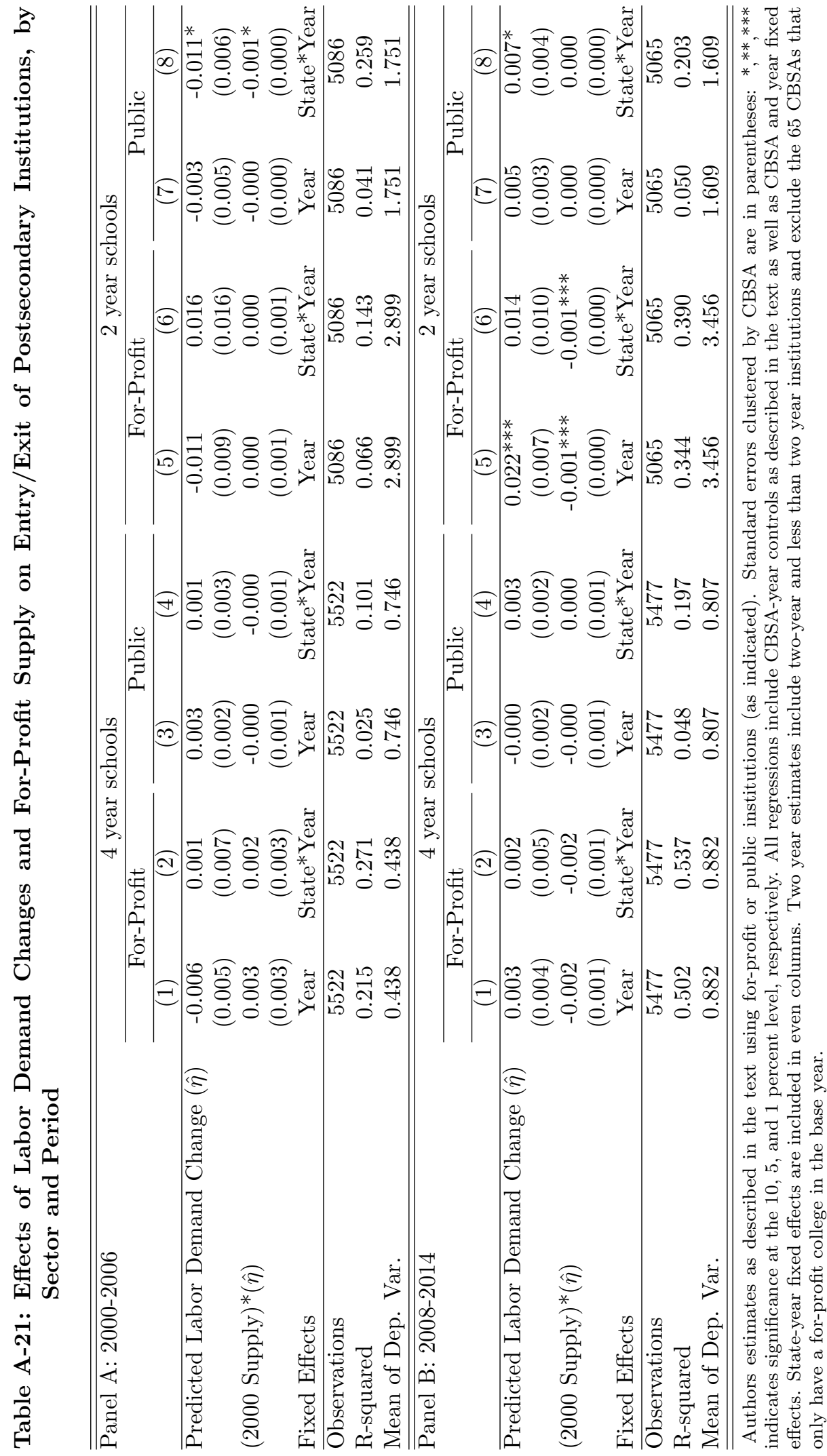


Table A-22: Data Ranges and Cohorts for Outcomes

\begin{tabular}{lrc}
\hline \hline Outcome Variables & $\begin{array}{c}\text { Data Ranges } \\
(1)\end{array}$ & $\begin{array}{r}\text { Cohorts } \\
(2)\end{array}$ \\
\hline Number of Recipients: Direct Subsidized loans & $2000-2014$ & $2000-2014$ \\
Number of Recipients: Direct Unsubsidized loans & $2000-2014$ & $2000-2014$ \\
Number of Recipients: FFEL Subsidized loans & $2000-2014$ & $2000-2014$ \\
Number of Recipients: FFEL Unsubsidized loans & $2000-2014$ & $2000-2014$ \\
Number of Federal Loans & $2000-2014$ & $2000-2014$ \\
Loan Origination Amounts & $2000-2014$ & $2000-2014$ \\
Number of Borrowers in Default, assuming 100\% completion time (2 year schools) & $2002-2011$ & $2000-2009$ \\
Number of Borrowers in Default, assuming 100\% completion time (4 year schools) & $2004-2011$ & $2000-2007$ \\
Number of Borrowers in Default, assuming 150\% completion time (2 year schools) & $2003-2011$ & $2000-2008$ \\
Number of Borrowers in Default, assuming 150\% completion time (4 year schools) & $2006-2011$ & $2000-2005$ \\
Number Employed, 6 years after enrollment & $2005-2011$ & $2001-2006$ \\
Total Earnings, 6 years after enrollment & $2005-2011$ & $2001-2006$ \\
Number of Students Making \$25k, 6 years after enrollment & $2005-2011$ & $2001-2006$ \\
Number of Students Graduated, assuming 150\% completion time (2 year schools) & $2002-2013$ & $2000-2011$ \\
Number of Students Graduated, assuming 150\% completion time (4 year schools) & $2005-2013$ & $2000-2008$ \\
\hline \hline
\end{tabular}

